\title{
ANTIHYPERTENSIVE TREATMENT AS A POSSIBLE CAUSE OF STROKE IN THE ELDERLY
}

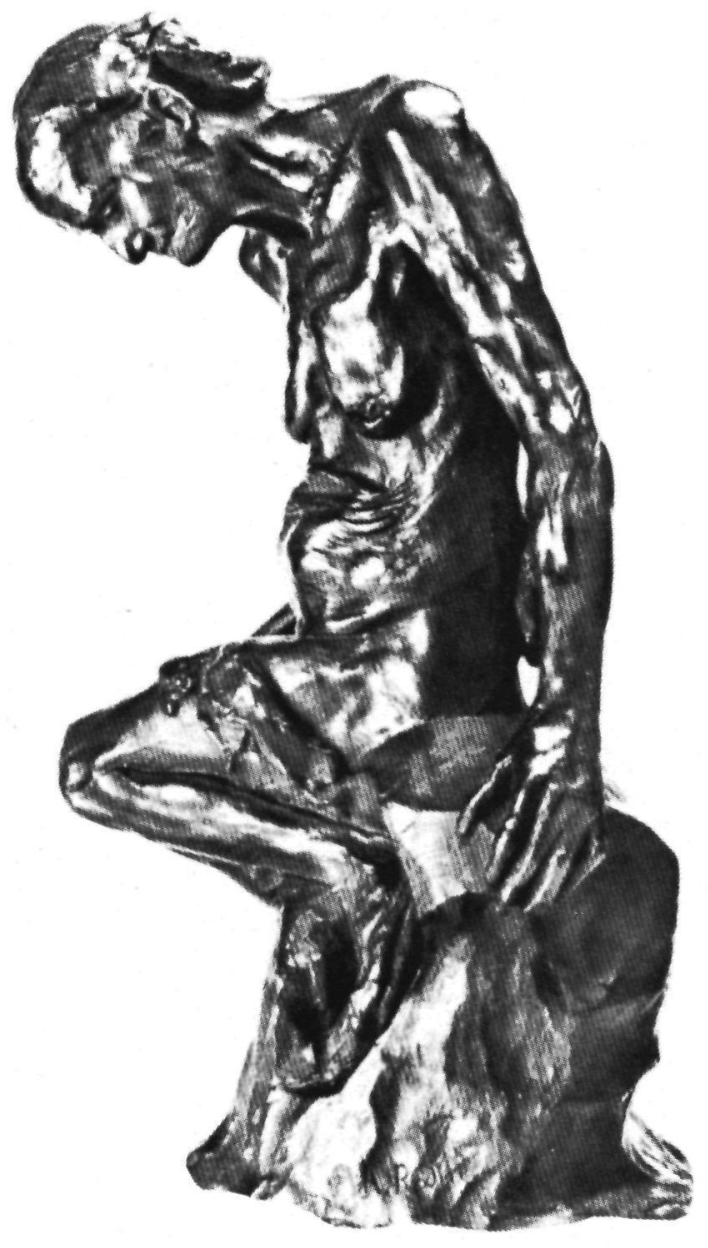

Paul A.F. Jansen 

ANTIHYPERTENSIVE TREATMENT

AS A POSSIBLE CAUSE

OF STROKE IN THE ELDERLY 
Omslag: Auguste Rodin (1880/1883): Celle qui fut la belle Heaulmière (Eens was zij de mooie Heaulmière) 


\title{
ANTIHYPERTENSIVE TREATMENT AS A POSSIBLE CAUSE OF STROKE IN THE ELDERLY
}

\author{
PROEFSCHRIFT
}

\author{
ter verkrijging van de graad van doctor \\ in de Geneeskunde aan de Katholieke \\ Universiteit te Nijmegen \\ op gezag van de Rector Magnificus \\ Prof. Dr. J.H.G.I. Giesbers \\ volgens besluit \\ van het College van Decanen \\ in het openbaar te verdedigen \\ op vrijdag 28 november 1986 \\ des namiddags te 1.30 uur precies
}

door

PAULUS ADRIANUS FRANCISCUS JANSEN

geboren te Haarlem 
Promotores: Prof.Dr. F.W.J. Gribnau

Prof.Dr. B.P.M. Schulte 
Aan Marjan

en mijn ouders 
The studies presented in this thesis were performed in the Laboratory of Pharmacology, nivision Clinical Pharmacology and Pharmacokinetics, the Department of Internal Medicine, Division General Internal Medicine, the Institute of Neurology, Sint Radboud Hospital, Catholic University Nijmegen, and the Department of Neurology, CanisiusWilhelmina Hospital, Nijmegen, The Netherlands.

This study was supported by a grant from Merck, Sharp and Dohme, Haarlem, The Netherlands; financial support by the Netherlands Heart Foundation for the publication of this thesis is gratefully acknowledged. 
CONTENTS

Chapter 1. Introduction and aim of the study

Chapter 2. Stroke after starting ant ihypertensive treatment; assessment of a possible causal relationship

Chapter 3. Cerebral ischaemia and stroke as side effect of antihypertensive treatment; special danger in the elderly. A review of cases reported in literature

Chapter 4. Antihypertensive treatment as a possible cause of stroke in the elderly

Chapter 5. Contribution of inappropriate treatment for hypertension to pathogenesis of stroke in the elderly

Chapter 6. Cerebral infarction as consequence of inappropriate antihypertensive treatment

Chapter 7. Course of blood pressure after cerebral infarction and transient ischaemic attack

Chapter 8. Blood pressure and both venous and urinary catecholamines after cerebral infarction

Chapter 9. Summary and conclusions 

The elderly are the most fastly growing age aroud in The Netherlands and in many other western countries. With increasing age, multiple disease states (multiple pathology) are more common; it is therefore not surprising that the elderly are consumers of many drugs (polypharmacy). In old people, as compared with the young, the pharmacokinetics and pharmacodynamics of several drugs are alter$\mathrm{ed}^{1-4}$; it is often necessary to adjust the dose of drugs and a thorough knowledge of what might be called geriatric pharmacology 5 is essential for appropriate drug treatment.

Due to the altered response to drugs and due to polypharmacy (giving rise to interactions that are often unpredictable), adverse drug reactions (ADR) are more frequent in the aqed. Studies have shown that in patients over age 70 a twofold increase of ADR is seen as compared with the young ${ }^{6}$. To prevent iatrogenic disease it is therefore of importance to treat elderly patients, in general, with small doses of drugs; the dosage may be increased on the basis of clinical effects and in the absence of side effects. Assessment of a phenomenon such as $A D R$ is sometimes easy, but more often it is difficult to give full proof that a disease is druginduced. The spontaneous (i.e. voluntary and unasked) reports of doctors in general practice are the main method in the detection of $A D R$ in the society 8,9 . In Europe the reporting system with the yellow card to the centres for monitoring adverse drug reactions has proved to be of value 8 . In these centres $A D R$ are assessed and exchange of information with other centres takes place. The detection of an AnR becomes more difficult when a drug induces a disease, whereas the drug was prescribed precisely to prevent that disease. The disease may be ascribed to a failure of therapy and the possibility of an ADR may not be considered by the clinician.

This thesis comprises studies on stroke as a possible side effect of antihypertensive treatment in the elderly. The study was prompted by 
an observation of Gribnau (personal communication). A close elderly relative of his suffered a stroke shortly after her general practitioner prescribed furosemide because of hypertension. She recovered completely; the furosemide was stopped. After a few monthsthe general practitioner again prescribed furosemide because of hypertension. Shortly thereafter stroke recurred and proved to be irreversible. Neurologists, asked about their familiarity with this "side effect of antihypertensive treatment", considered it not uncommon. However, in the literature only a few cases have been reported and stroke as side effect of antihypertensive treatment with furosemide has not been reported at all to the Netherlands Centre for Monitoring Adverse Drug Reactions.

The aim of the study was to answer the following questions:

- does stroke occur as a side effect of antihypertensive treatment?

- which drugs are responsible for this ADR?

- are the elderly especially at risk to develop this ADR?

- what is the frequency of this $A D R$ in patients hospitalised for recent stroke?

Since hypertension is the most powerful risk factor for stroke 13 and antihypertensive treatment is intended to prevent it, the detection of stroke as side effect of antihypertensive treatment is difficult. For assessment of ADR, to define side effects as unlikely (or doubtful), possible, probable or definite, several methods and algorithms are in use14-16. The value of these methods and algorithms in the assessment of stroke as ADR of antihypertensive treatment is discussed in Chapter 2.

A review of cases of drug-induced cerebral ischaemia reported in the literature is given in Chapter 3.

Since the outcome of stroke is often an irreversible hemipares is and patients are rehabilitated in nursing homes, if possible, we expected to find cases in this population. We asked all medical directors of Dutch nursing homes ( $n=322)$ to report suspected cases of drug-induced stroke; this inquiry is presented in Chapter 4.

To obtain information on the frequency of the suspected ADR, 100 patients admitted with cerebral infarction or transient ischaemic 
attack (TIA), were studied in the 3 weeks before the event, as to blood pressure course and as to signs of hypovolaemia; this study is presented in Chapter 5.

of the 100 patients studied, one categorv was considered separately; this group comprised only patients receiving antihypertensive medication. This study, including case histories, is presented in chapter 6.

In the first days after stroke, blood pressure is usually increased17-20. It is still under discussion whether post-stroke hypertension should be treated21-23. There are reports that blood pressure reduction after stroke might be dangerous and aggravate cerebral ischaemia24. We studied the natural course of blood pressure before, the first days after and several months after stroke; these data are presented and discussed in Chapter 7.

The mechanism of the blood pressure increase after stroke is still unknown. A relationship with the stress of the event has been suggested, but also neuronal (dys)regulation 25,26 . We studied preliminarily the relation between the course of blood pressure and both plasma and urinary catecholamines on the first three days after cerebral infarction; this study is presented in Chapter 8.

The final chapter gives a summary of the findings and formulates conclusions. 


\section{REFERENCES}

1. WHO. Health care in the elderly: Report of the Technical Group on use of medicaments by the elderly. Drugs 1981; 22 : 279-94.

2. Ouslander J. Drug therapy in the elderly. Ann Int Med 1981; 95 : 711-22.

3. Koch-Weser J, Greenblatt DJ, Sellers EM and Shader RI. Orug therapy. Drug disposition in old age. N Eng J Med 1982; 306 : 1081-8.

4. Shaw PG. Common pitfalls in gertatric druq prescribing. Drugs 1982; 23 : 324-8.

5. Bender $A D$. Geriatric pharmacology - a descriptive definition. J Am Geriatr Soc 1967; 14 : 1013-5.

6. Jue $S G$ and Vestal RE. Adverse drug reactions in the elderly. In: D'Malley $K$ (ed) Clinical pharmacology and drug treatment in the elderly. Churchill Livingstone, Edinburgh 1984; 39-51.

7. Hurwitz $H$. Predisposing factors in adverse reactions to druqs. Br Med J 1969; I : 536-9.

8. Inman $W$. Adverse reactions to new drugs. Br Med J 1983; 286 : 719-20.

9. Rossi $A C$ and Knapp DF. Discovery of new adverse drug reactions. A review of the food and drug administrations spontaneous reporting system. JAMA 1984; 252 : 1030-3.

10. Cove $D H$, Seddon $M$, Fletcher $R D$ and Dukes $D C$. Blindness after treatment for malignant hypertension. Br Med J 1979; II : 245-6.

11. Ledingham JGG and Rajagopalan B. Cerebral complications in the treatment of accelerated hypertension. Q J Med 1979; 48 : 25-41.

12. Strandgaard $S$, Andersen GS, Ahlgreen $P$ and Nielsen PE. Visual disturbances and occipital brain infarct following acute, transient hypotension in hypertensive patients. Acta Med Scand 1984 ; 216 : 417-22.

13. Kannel WB, Wolf PA, Verter $J$ and McNamara PM. Epidemiologic assessment of the role of blood pressure in stroke: The Framingham Study. JAMA 1970; 214 : 301-10.

14. Karch FE, Lasagna L. Toward the operational identification of adverse drug reactions. Clin Pharmacol Ther 1977; 21 : 247-54. 
15. Kramer MS, Leventhal JM, Hutchinson TA and Feinstein AR. An algorithm for the operational assessment of Adverse Drug Reactions. JAMA 1979; $242: 623-32$.

16. Naranjo CA, Busto $U$, Sellers EM et al. A method for estimating the probability of adverse drug reactions. Clin Pharmacol Ther $1981 ; 30: 239-45$.

17. Faire $U$ de, Britton $M$, Helmers $C$ and Wester P0. Blood pressure during the acute phases of cerebrovascular disease. Acta Med Sc and 1978; (Supp1 88) : 621-27.

18. Wallace 30 and Levy LL. Blood pressure after stroke. JAMA 1981; 246 : 2177-80.

19. Loyke HF. Lowering of blood pressure after stroke. Am J Med 1983; 286 : 2-11.

20. Schulte BPM, Leyten ACM and Herman B. Pre-stroke and immediate post-stroke hypertension: neuro-epidemiological data. In: Meyer JS, Lechner $H$, Reivich M, Ott E (eds) Cerebral Vascular Disease 5 (12th Salzburq Conference), Excerpta Medica, AmsterdamNew York-0xford 1985; 286.

21. Yatsu FM and Zivin J. Hypertension in acute ischemic strokes. Not to treat. Arch Neurol 1985; 42 : 999-1000.

22. Spence JD and Del Maestro RF. Hypertension in acute ischemic strokes; treat. Arch Neurol 1985; 42 : 1000-2.

23. Hachinski $V$. Hypertension in acute ischemic strokes. Arch Neurol $1985 ; 42$ : 1002.

24. Britton M, Faire $U$ de and Helmers C. Hazards of therapy for excessive hypertension in acute stroke. Acta Med Scand 1980; 207: 253-7.

25. Melamed E, Cooper G, Saltstein E and Globus M. Transitory elevations in arterial blood pressure in patients with acute cerebral ischemia: incidence, natural history and clinical significance. Abstract 2nd International Symposium on Rrain-Heart Relationship, Jerusalem 1983.

26. Conomy JP, Barnes $\mathrm{KL}$ and Ferrario $\mathrm{CM}$. The brain and arterial hypertension: new direction in an old relationship. Neurol 1978; 28 : 1203-5. 


\section{CHAPTER 2}

STROKE AFTER STARTING ANTIHYPERTENSIVE TREATMENT; ASSESSMENT OF A POSSIBLE CAUSAL RELATIONSHIP

PAF Jansen, RHB Meyboom, FWJ Gribnau, BPM Schulte 

INTRODUCTION

Adverse drug reactions (ADR) are drug-induced clinical manifestations, that are noxious, unintended and occur at doses normally used in $\operatorname{man}^{1}$. They are a considerable cause of morbidity and sometimes even lead to death. Drugs may induce a large variety of symptoms and disorders, and in many patients drugs should be considered as a possible cause of disease. Efficient methods of detecting ADR include the yellow card reporting system in Europe ${ }^{2}$, and the spontaneous reporting system in the USA ${ }^{3}$; published anecdotal reports are also considered of great value 4,5 .

Assessment of the relationship between a drug and a suspected adverse reaction is, however, notoriously difficult. Onlv very rarely is a disorder pathognomonic for a drug, and diagnostic tests to confirm involvement of the druq are mostly not available. As a rule, anv medical diagnosis entails a certain amount of incertitude. In many diseases in which there is no critical test, a systematic procedure of diagnosis has been developed, which includes sets of essential and secondary criteria. Accordingly, a number of diagnostic models have been designed for assessment of the likelihood of a disorder being drug-induced6-14. The purpose of these efforts was to unify the procedure and to improve the objectivity of diagnosis. These approaches usually take into account a number of critical questions, have the form of an "algorithm" and provide a calculated degree of likelihood which is expressed in an addition sum and an associated causality term, e.g. unlikely, posstble, probable and definite.

We have elsewhere provided evidence that starting of antihypertensive treatment in the elderly may provoke cerebral ischaemia and even stroke when the fall of blood pressure is too rapid or too steep 15 . In those patients reasons to assume a causal relation with the treatment were:

- the apparent association in time;

- a marked fall of blood pressure after the event, as compared with that prior to treatment, while usually there is an increase of blood pressure after stroke;

- signs of circulatory volume depletion. 
In an attempt to improve the causal diagnosis in our patients, we applied the best-known druq-reaction assessment algorithms as described in literature 7,8 .

Assessment of cerebral infarction as ADR to antihypertensive treatment

The algorithm of Kramer et al. ${ }^{7}$ comprises six major axes of decision strategy with a scoring system incorporated in each axis. An outline of the scoring strategy is presented in Table I. The first axis concerns previous general experience with the drug. In our cases furosemide was prescribed (in a non-slow-release dosage form), because of hypertension; the indication for prescribing furosemide is usually congestive heart failure; it is not clear how often furosemide is prescribed for hypertension. One study mentions use of furosemide because of hypertension in $1.4 \%$ of the patients 16 . Recause the drug is widely used, enough clinical experience is available to make it likely that most ADR due to furosemide have been reported. The question remains whether this completeness of case finding may also be assumed regarding furosemide in the treatment of hypertension. To our knowledge the literature comprises 4 reports on signs of cerebral ischaemia after use of furosemide, given in combination with other antihypertensive drugs17-19. Because the clinical manifestation is not well known, but previously reported, the score on axis $I$ is 0 .

Axis II concerns alternative causes of the clinical manifestation, e.g. underlying clinical conditions, or diagnostic or therapeutic interventions. Because hypertension is the most important risk factor for stroke 20 , the clinical manifestation (i.e. cerebral infarction) can be explained as a result of the blood pressure increase, and is a good alternative candidate. The score is -1 .

Axis III concerns relationship in time between start of the drug and clinical manifestation. Because furosemide was started within 2 weeks before the event and in that time may have caused hypovolaemia, a time relationship may be present and the score on axis III can be +1 . Axis IV concerns evidence of overdose of the drug. It could be assum- 
TABLE I

Scoring strategy according to $\mathrm{Kramer}$ et al.7. Definite $>6$, probable 4-5, possible 0-3, unlikely $<0 \quad(\mathrm{CM}=$ clinical manifestation)

score

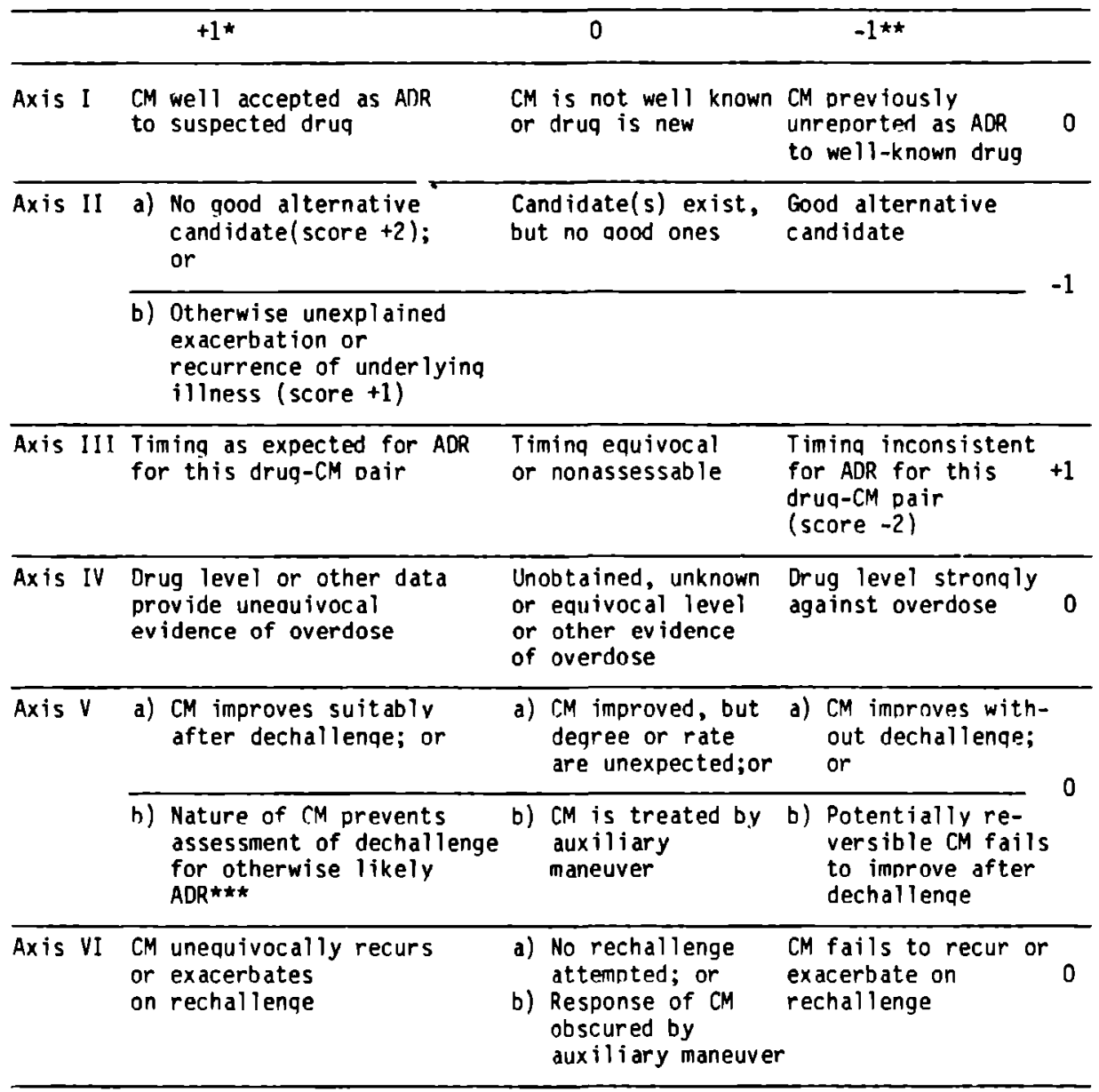

* Except where noted as +2

$\star \star$ Except where noted as -2

$\star \star \star A D R$ is likely when score on axis is I-IV $>3$ 
ed that the patients took the prescribed dose and that there is no evidence of overdose. The score is 0 .

Axis $V$ concerns dechallenge; in our cases dechallenge cannot be assessed because withdrawal of the causative agent is independent of the resolution of organ damage. In the case of cerebral infarction the outcome of the damage is often irreversible. The nature of the clinical manifestation therefore prohibits assessment of dechallenge. As the ADR is "not likely", and the score on axis I-IV is <3, the score on axis $V$ is 0 .

Axis VI concerns rechallenge; when stroke proved to be irreversible, rechallenge is of no value; when the patients after stroke improve, rechallenge should not be attempted in our opinion, because of the seriousness of the inspected $A D R$ and chance for irreversibility of the clinical manifestation. The score on the last axis is 0 . The total score according to the algorithm is 0 and the ADR is assessed as possible.

As Naranjo et al. 8 found the algorithm of Kramer et al. 7 too detailed and time-consuming, they developed a simple method to assess the causality of ADR (Table II). In this method the answer to the first question, concerning conclusive reports on cerebral infarction as side efr ct of antihypertensive treatment with furosemide, is negative (score 0 ). The second question, concerning time relationship, is positive and gives a score of +2 . The third question, concerning improvement after discontinuation of the druq is to be answered with no (score 0 ) because of the frequent irreversibility of the clinical manifestation. For the same reason it is difficult to answer question 4 (readministration of the drug), question 6 (reappearance of the reaction after administration of a placebo), question 8 (relation with dose) and question 9 (previous exposure to similar drugs) in all cases giving score 0 . The fifth question on alternative causes, has to be answered yes, because hypertension is a good alternative candidate (score -1). The answer to question 7 , concerning blood levels of the drug, is no (score 0 ). Finally, the answer to question 10 (objective evidence of the adverse event) may be answered positively when the signs of stroke are considered as objective 
TABLE II

Scoring strategy according to Naranjo et al.8. Definite $>9$, probable 5-8, possible 1-4, doubtful $<0$.

\section{Yes No Do not know Score}

1. Are there previous conclusive reports on

$+10$

0 this reaction?

2. Did the adverse event appear after the

$+2 \quad-1$
suspected drug was administered?

3. Did the adverse reaction improve when the

$+10$

0 druq was discontinued or a specific antagonist was administered?
4. Did the adverse reaction reappear when the $+2 \quad-1 \quad 000$ drug was readministered?
5. Are there alternative causes (other than $-1+2 \quad 0 \quad-1$ the drug) that could on their own have caused the reaction?
6. Did the reaction reappear when a olacebo $\quad-1+1 \quad 00$ was qiven?

7. Was the drug detected in the blood (or other $+1 \quad 0 \quad 00$ flutds) in concentrations known to be toxic?
8. Was the reaction more severe when the dose $+1 \quad 0 \quad 0 \quad 0$ was increased, or less severe when the dose was decreased?

9. Did the patient have a similar reaction to the same or similar druas in any previous exposure?

10. Was the adverse event confirmed by any objective evidence?

$\begin{array}{cccc}+1 & 0 & 0 & +1 \\ & & \text { Total score } & +2\end{array}$


DISCUSSION

According to two commonly used grading methods for assessing ADR, cerebral infarction as side effect of antihypertensive treatment with furosemide was regarded as possible. Another important algorithm (that of Karch and Lasagna) ${ }^{6}$, is not discussed because of its complexity; according to this algorithm the ADR was assessed as unrelated, because the event could be expected in hypertensive patients. Nevertheless, we believe that there are factors, not incorporated in the above mentioned alcorithms and methods, that point to furosemide treatment as the cause of the cerebral infarction in the three patients mentioned. Firstly, attention must be given to the fall in blood pressure; a fall in blood pressure after starting antihypertensive treatment is intended and to be expected. However, a marked fall in blood pressure after stroke is uncomon; after stroke blood pressure is usually increased and studies have pointed out that, in $95 \%$ of the patients with stroke, blood pressure was increased as compared with pre-stroke values $21-24$. Most patients with cerebral infarction we studied, also had an increased blood pressure after stroke. The fall in blood pressure in the three patients* we suspected of having the alleged ADR, was greater than in any other patient we studied, and is therefore remarkable. Normally, the brain is protected against blood pressure fluctuations by autorequlation: when blood pressure rises, cerebral vessels constrict and when blood pressure falls, cerebral vessels dilate, resulting in a constant cerebral blood flow in ranges of 60 to $150 \mathrm{~mm}$ g mean arterial blood pressure (MAP) 25 . Beyond these values, there is failure of autoregulation. In patients with hypertension, however, the autorequlatory curve is shifted to the right, resulting in impairment of blood flow already at levels higher than $60 \mathrm{mmHg}^{25}$. Another point of interest is the age of the patients. All three patients were elderly $(67,72$ and 72 years). It is known that in the elderly a fall in blood pressure cannot be compensated as adequately

* The case histories of these patients are presented in Chapter 6. 
as in the young. The baroreflex is less sensitive 26 and there may be failure of autoregulation of the brain in old age 27 , making cerebral blood flow directly dependent on blood pressure. A relatively minor fall in blood pressure can cause cerebral ischaemia in such a situation. A last point of importance are the laboratory data of the three patients, providing evidence of hypovolaemia induced by the furosemide diuresis (high haematocrit values $>0.481 / 1$ and relatively high plasma albumin concentrations $>42 \mathrm{q} / 1)$. Cerebral blood flow decreases also with high haematocrit $(>0.461 / 1)$, resulting in cerebral ischaemia28. Although clinical evidence suggests that cerebral infarction was induced by antihypertensive treatment with furosemide in the 3 elderly hyoertensive patients, the commoniy used algorithms and methods give 1 ittle 7,8 or no ${ }^{6}$ support.

There are many difficulties in detecting stroke as ADR to antihypertensive treatment. Since hypertension is the major risk factor for stroke, the development of stroke a few days after starting antihypertensive treatment may be a coincidence. Because of a persistent neurological deficit after stroke, dechallenge and rechallenge are of no value in most cases. In the case of reversibility of the siqns, rechallenge is not feasible for ethical reasons. The literature reports one case of retinal ischaemia as side effect of oral nifedipine ${ }^{29}$; after cessation of the drug the signs disappeared; after rechallenge with nifedipine, blindness as a consequence of retinal ischaemia returned; after cessation of nifedipine the blindness proved to be reversible again.

In conclusion, the algorithms used to assess stroke as ADR to antihypertensive treatment are of little value. Invariably there was a low score, mainly because the ADR was considered not to be well known, hypertension as a cause of stroke is a good alternative and dechallenge and rechallenge are of no value in view of the possible irreversibility of stroke. In the case of a suspected adverse reaction that is not well-known and resembles an otherwise not uncommon disorder, a careful search is needed for signs or symptoms that are unusual in the spontaneous disease. Uniformity of diagnosis may only be achieved in a sensible way with the aid of a specially designed algorithm. 


\section{REFERENCES}

1. WHO. International Drug Monitoring. WHO Tech Rep Ser 1972; 498 : 8-9.

2. Inman $W$. Adverse reactions to new drugs. $\mathrm{Br}$ Med $\mathrm{J} 1983 ; 286$ : 719-20.

3. Rossi $A C$, Knapp DE. Discovery of new adverse drug reactions. A review of the food and drug administration's spontaneous reporting system. JAMA 1984; 252 : 1030-3.

4. Venning G. Validity of anecdotal reports of suspected adverse drug reactions. Br Med J 1982; 284 : 249-52.

5. Venning $G$. Identification of adverse reactions to new drugs. $\mathrm{Br}$ Med J 1983; 286 : 199-202; 289-92; 365-8; 458-60; 544-7.

6. Karch FE, Lasagna L. Toward the operational identification of adverse drug reactions. Clin Pharmacol Ther 1977; 21 : 247-54.

7. Kramer MS, Leventhal JM, Hutchinson TA, Feinstein AR. An algorithm for the operational assessment of Adverse Drug Reactions. JAMA 1979; $242: 623-32$.

8. Naranjo CA, Busto $U$, Sellers $E M$ et al. A method for estimating the probability of adverse drug reactions. Clin Pharmacol Ther $1981 ; 30: 239-45$.

9. Dangoumau J, Evreux, J-C and Jouglard J. Methode d'imputabilité des effects Indésirables des Médicaments. Therapie 1978; 33 : 373-81.

10. Blanc S, Leuenberger $P$, Berger J-P, Brooke EM and Schelling J-L. Judgements of trained observers on adverse drug reactions. $\mathrm{Cl}$ in Pharmacol Ther 1979; $25: 493-8$.

11. Emanueli $A$ and Saccheti G. An algorithm for the classication of untoward events in larqe scale clinical trails. Agents Actions 1980; 7 : 318-22.

12. Venulet $J$, Ciucci $A G$ and Berneker GC. Standardized assessment of drug-adverse reaction associations - Rationale and experience. Int J Clin Pharmacol Ther Toxicol 1980; 18 : 381-8.

13. Lagier $G$, Vincens $M$, Castot $A$, and Efthymiou $M-L$. Diagnostic differential des leucopenies médicamenteuses. Therapie 1982; 37 : 377-84. 
14. Lagier G, Vincens $M$ and Castot A. Imputabilité en Pharmacovigilance. Therapie 1983; $38: 303-18$.

15. Jansen PAF, Schulte BPM, Meyboom RHB, Gribnau FWJ. Ant ihypertensive treatment as a possible cause of stroke in the elderly. Age Ageing 1986; 15 : 129-38.

16. Greenblatt DJ, Duhone DW, Allen MD, Koch-Weser J. Clinical toxicity of furosemide in hospitalized patients. A report from the Boston collaborative drug surveillance program. Am Heart $J$ 1977; $94: 6-13$.

17. Ledingham JGG, Rajagopalan B. Cerebral complications in the treatment of accelerated hypertension. $0 \mathrm{~J}$ Med 1979; $48: 25-41$.

18. Cove $D H$, Seddon $M$, Fletcher RF, Dukes $D C$. Blindness after treatment for malignant hypertension. Br Med J 1979; II : 245-6.

19. Strandgaard S, Andersen GS, Ahlgreen P, Nielsen PE. Visual disturbances and occipital brain infarct following acute, transient hypotension in hypertensive patients. Acta Med Scand 1984; 216 : 417-22.

20. Kanne1 WR, Wolf PA, Verter J, MCNamara PM. Epidemiologic assessment of the role of blood pressure in stroke: the Framingham Study. JAMA 1970; 214 : 301-10.

21. Wallace JD, Levy LL. Blood pressure after stroke. JAMA 1981; $246: 2177-80$.

22. de Faire U, Britton $M$, Helmers $C$, Wester PO. Blood pressure during the acute phases of cerebrovascular disease. Acta Med Scand 1978; Supp1 621 : 27.

23. Schulte BPM, Leyten ACM, Herman B. Pre-stroke and immediate poststroke hypertension: neuroepidemiological data. In: Meyer JS, Lechner U, Reivich $M$, ott $E$ (eds) Cerebral Vascular Disease 5 (12th Salzburg Conference). Excerpta Medica, Amsterdam-New York0xford 1985; 286.

24. Loyke HF. Lowering of blood pressure after stroke. Am J Med 1983; 286 : 2-11.

25. Strandgaard $S$. Autoregulation of cerebral blood flow in hypertensive patients. Circulation 1976; $53: 720-7$. 
26. Gribbin B, Pickering TG, Sleight P, Peto R. Effect of age and high blood pressure on baroreflex sensitivity in man. Circulation Res 1971; 29 : 424-31.

27. Wollner L, MCCarthy ST, Soper NDW, Macy DJ. Failure of cerebral autoregulation as a cause of brain dysfunction in the elderly. Br Med J 1979; I : 1117-8.

28. Thomas DJ, Marshall J, Ross Russell RM et al. Effect of haematocrit on cerebral blood flow in man. Lancet 1977; II : 941-3.

29. Pitlik S, Manor RS, Lipshitz I, Perry G, Rosenfeld J. Transient retinal ischaemia induced by nifedipine. Br Med J 1983; 287 : 1845-6. 
CEREBRAL I SCHAEMIA AND STROKE AS SIDE EFFECT OF ANTIHYPERTENSIVE

TREATMENT; SPECIAL DANGER IN THE ELDERLY

A review of cases reported in literature

PAF Jansen, BPM Schulte, FWJ Gribnau

Submitted for publication 


\section{SUMMARY}

There are few reports on cerebral ischaemia or stroke as possible side effect of antihypertensive treatment. This review presents cases reported in the literature. Especially elderly hyoertensive patients seem to be at risk for this unintended and paradoxical side effect of antihypertensive treatment, because they are more sensitive than the young for complications, when a rapid and/or marked fall in blood pressure is obtained. Possible explanations for the increased predisposition to complications are discussed. For antihypertensive treatment in the elderly it is advisable to start with a small dose of an appropriate antihypertensive drug, aiming at a slow decrease in blood pressure. 
INTRODUCTION

Hypertension is the most important risk factor for stroke1,2. In the aged, systolic hypertension in particular is a powerful contributor to stroke incidence $3-5$. Effective antihypertensive treatment has proved to reduce morbidity and mortality from stroke, also in the elderly6-9. In the reduction of stroke recurrence, antihypertensive treatment is of benefit as well10,11; in the aged however, effective antihypertensive treatment has not been proved to prevent stroke recurrence12,13. In an elderly patient with hypertension one should at least consider starting antihypertensive treatment, although there is no consensus about the level of diastolic or systolic pressure above which one should start treatment. In common clinical practice the rule is to institute antihypertensive drugs in elderly patients with hypertension (i.e. systolic $>160 \mathrm{mmHg}$ and/or diastolic $>95 \mathrm{mmHg}$ according to the wHO ${ }^{14}$ ) with a sustained diastolic pressure of $115 \mathrm{mmHg}$ or more, with diastolic pressures in the range $100-114 \mathrm{mmHg}$ in the presence of complications or a systolic pressure greater than $180 \mathrm{mmH}^{15,16}$.

Apart from beneficial effects, drugs also cause negative effects.Some are dose-independent, but most are dose-dependent. Especially in the elderly, one should beware of side effects of drugs in view of changes in pharmacokinetics, pharmacodynamics and of polypharmacy often needed for multiple pathology17,18.

We studied stroke as a side effect of antihypertensive treatment in the elderly19. This review of the literature presents the other reported cases on cerebral ischaemia or stroke as possible side effect of antihypertensive treatment and on other drugs inducing hypotension.

Cerebral ischaemia due to drug-induced hypotension

In Table I the cases from the literature are summarized20-33. Cerebral ischaemia caused by hypotension is reported as side effect of all kinds of antihypertensive agents, both the powerful, like diazoxide, and more commonly used antihypertensive drugs such as B-blocking drugs, diuretics, vasodilators and ACE inhibitors. 
Graham20 was the first to describe two patients with ischaemic brain damage induced by a hypotensive period after starting bethanidine (a guanethidine derivative) and pentolinium (a qanqlion-blocking drug) treatment respectively. Post-mortem examination revealed ischaemic damage in the "border zone" (i.e. the area between the major arterial territories of the brain) implicating the hypotensive period as a likely cause of the brain damage. The importance of such pathological findings has been shown by Adams et al34; they found border zone lesions in patients after a precipitate reduction in systemic blood pressure, and more diffuse changes in patients with sustained hypotension.

Jackson et al21 described 6 elderly patients with signs of cerebral ischaemia presented shortly after starting methyldopa $(n=5)$ in a dose of $3 \times 250 \mathrm{mg}$ daily and the B-blocker oxprenolol $(n=1)$. In the patient aged 84 years we calculated a fall in mean arterial blood pressure (MAP) of 11\%. The others all showed a more marked fall in blood pressure. When treatment was stopped, blood pressure returned to pretreatment levels and the patients improved, although one had residual left-sided homonymous hemianopsia.

Kumar et al.22 presented a patient with persistent right-sided hemiplegia after hypotension induced by diazoxide. Blood pressure fell from very high $(290 / 160 \mathrm{mmHg})$ to an unrecordable level. Another patient described by these authors suffered myocardial infarction after diazoxide induced hypotension (not in the Table).

Cove et a ${ }^{23}$ reported blindness in two young patients after a rapid fall in blood pressure as a consequence of vigorous treatment for malignant hypertension, in one with methyldopa $500 \mathrm{mg}$ six-hourly and propranolol $80 \mathrm{mg}$ eight-hourly, and in the other with a combination of diazoxide, furosemide and atenolol. The blindness was irreversible in both patients.

Ledinghan and Rajagopalan 24 described ten patients who developed neurological signs upon a rapid reduction of arterial pressure with the powerful antihypertensive drug diazoxide in nine cases (in eight combined with other antihypertensive agents) and a combination of hydralazine, amiloride and propranolol in one patient. Three died; 
IABLE 1. CASES OF CEREBRAL ISCHAEMIA DUE TO DRUG INDUCED hYPOTENSION (BP=Blood Pressure;

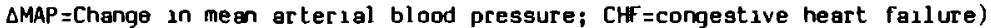

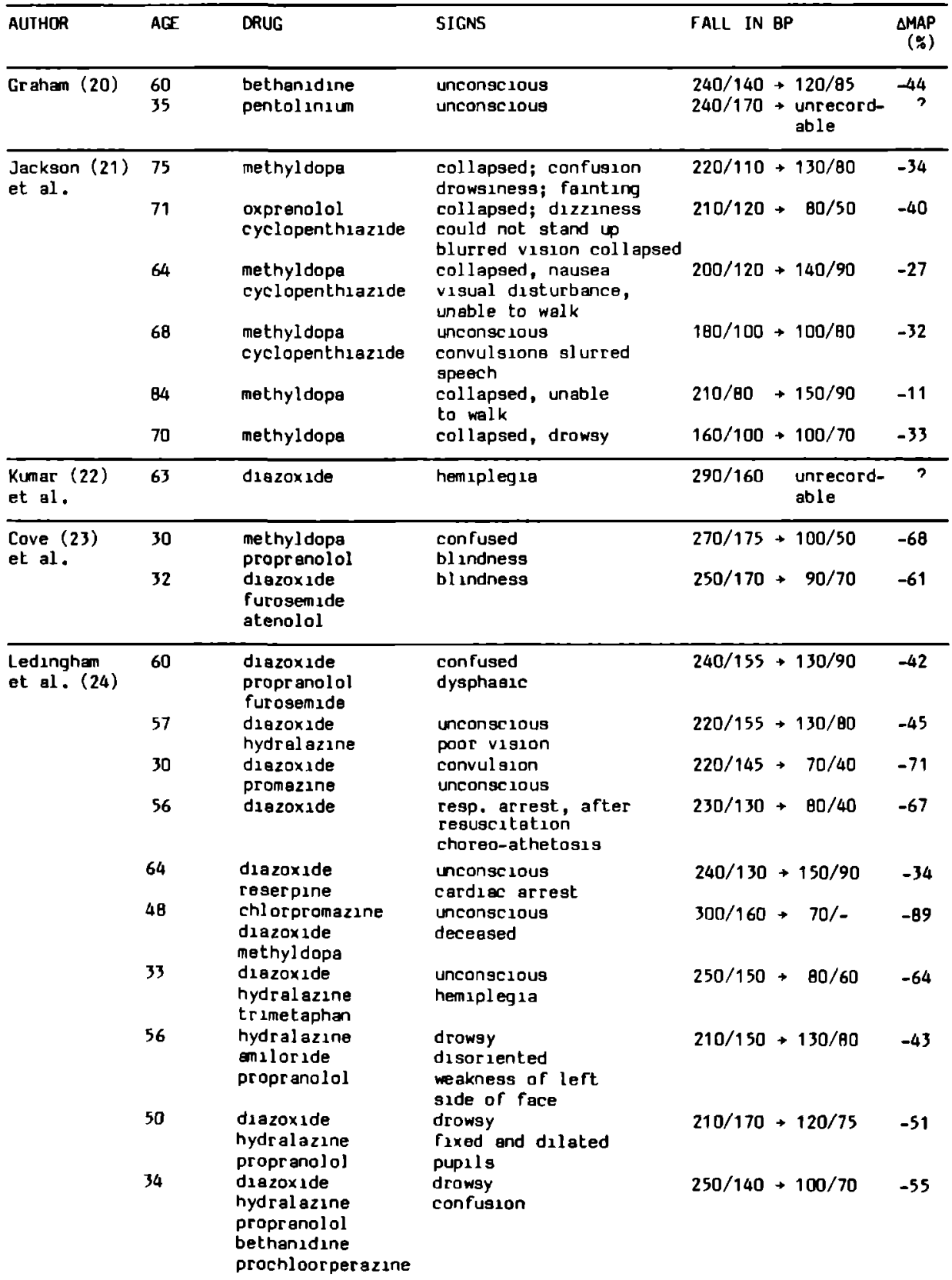


the postmortem revealed areas of ischaemic damage in the brain. Four patients were left with some permanent neurological disability. Three patients recovered completely.

Phillips and Jones 25 described the death of a patient using $100 \mathrm{mg}$ atenolol. Four hours after taking the first tablet he complained of dizziness and weakness; complete hemiplegia developed; blood pressure was markedly decreased as compared with pretreatment levels; he became unconscious and died a few hours later.

Ruff et al.26 reported 6 patients developing transient ischaemic attacks (TIA) after a period of hypotension induced by antihypertensive therapy. Three of these patients had severe carotid artery stenosis (the first three aged 69, 72 and 69 years in Table I). All had previously been hypertensive.

Hodsman et al.27 described 6 hypertensive patients with sians of cerebral ischaemia (dizziness, dysphasia, hemiparesis, drowsiness, stupor) due to hypotension after the first dose of captopril. The captopril dose varied from 6.25 to $25 \mathrm{mg}$. After correction of blood pressure with infusions of anaiotensin II or saline the neurological signs resolved.

Pitlik et al.28 reported loss of vision in the left eye induced by nifedipine in an elderly man after an oral dose of $20 \mathrm{mg}$. Vision improved within the next few hours. Six hours later he was rechallenged with $20 \mathrm{mg}$ nifedipine, resulting in a decrease in blood pressure and again loss of vision in the left eye. Treatment with nifedipine was stopped and the left visual field defect resolved completely.

Haas et al.29 described a 37 year old woman treated with propranolol and nitroprusside because of severe hypertension. Blood pressure fell precipitously; she developed visual disturbances, became lethargic and confused, and died after a few days.

Strandgaard et al. 30 reported two patients treated with a combination of furosemide and chlorpromazine, with visual disturbances after an acute fall in blood pressure. After correction of the hypotension the patients regained normal visual acuity.

There are also reports on cerebral ischaemia, induced by hypotension, 
TABLE I (cont inued)

\begin{tabular}{|c|c|c|c|c|c|}
\hline $\begin{array}{l}\text { Phillips (25) } \\
\text { et al. }\end{array}$ & 50 & atenolol & $\begin{array}{l}\text { hemiparesis } \\
\text { deceased }\end{array}$ & $240 / 140+135 / 80$ & -57 \\
\hline $\begin{array}{l}\text { Ruff (26) } \\
\text { et al. }\end{array}$ & $\begin{array}{l}69 \\
72 \\
69 \\
81 \\
69 \\
73\end{array}$ & $\begin{array}{l}\text { diuretica } \\
\text { and } \\
\text { vasodilators } \\
\text { methyldops } \\
\text { dzuretica }\end{array}$ & $\begin{array}{l}\text { IIA } \\
\text { TIA } \\
\text { IIA } \\
\text { TIA } \\
\text { IIA } \\
\text { TIA }\end{array}$ & $\begin{array}{l}? \\
? \\
? \\
? \\
? \\
?\end{array}$ & $\begin{array}{l}-21 \\
-23 \\
-16 \\
-22 \\
-19 \\
-26\end{array}$ \\
\hline $\begin{array}{l}\text { Hodenan (27) } \\
\text { et ol. }\end{array}$ & $\begin{array}{l}67 \\
55 \\
? \\
? \\
? \\
?\end{array}$ & $\begin{array}{l}\text { captopr 1l } \\
\text { captopr } 11 \\
\text { captopr } 11 \\
\text { captopr } 11 \\
\text { captopr 11 } \\
\text { captopr 11 }\end{array}$ & $\begin{array}{l}\text { drowsiness } \\
\text { dysphasic } \\
\text { paresis left arm } \\
\text { drzziness } \\
\text { stupor } \\
\text { drowsiness } \\
\text { drowsiness }\end{array}$ & $\begin{array}{l}222 / 128 \rightarrow 48 / 44 \\
206 / 132 \rightarrow 130 / 88 \\
214 / 136 \rightarrow 76 / 58 \\
144 / 102 \rightarrow 60 / 40 \\
250 / 112 \rightarrow 90 / 58 \\
186 / 120 \rightarrow 110 / 50\end{array}$ & $\begin{array}{l}-72 \\
-35 \\
-60 \\
-60 \\
-57 \\
-51\end{array}$ \\
\hline $\begin{array}{l}\text { Pitlik (28) } \\
\text { et al. }\end{array}$ & 67 & nifedipine & $\begin{array}{l}\text { bl indness } \\
\text { retinal ischemia }\end{array}$ & $7 \quad+110 / 70$ & $?$ \\
\hline $\begin{array}{l}\text { Haas (29) } \\
\text { et al. }\end{array}$ & 37 & $\begin{array}{l}\text { propranolol } \\
\text { nitroprusside }\end{array}$ & $\begin{array}{l}\text { fainting, blindness } \\
\text { lethargic, confused } \\
\text { deceased }\end{array}$ & $220 / 120+110 / 50$ & -54 \\
\hline $\begin{array}{l}\text { Str andgaard } \\
\text { et al }(30)\end{array}$ & $\begin{array}{l}47 \\
61\end{array}$ & $\begin{array}{l}\text { furosemide } \\
\text { chlorpromazine } \\
\text { furosemide } \\
\text { chlorpromazine }\end{array}$ & $\begin{array}{l}\text { visual impairment } \\
\text { infarction } \\
\text { visual } \\
\text { impairment }\end{array}$ & $\begin{array}{l}240 / 130+180 / 90 \\
180 / 100+105 / 80\end{array}$ & $\begin{array}{l}-32 \\
-30\end{array}$ \\
\hline $\begin{array}{l}\text { Clel and (31) } \\
\text { et al. }\end{array}$ & $\begin{array}{l}64 \\
54 \\
69\end{array}$ & $\begin{array}{l}\text { ceptopr } 11 \\
\text { for CHF } \\
\text { ceptoprdl } \\
\text { for CHF } \\
\text { coptoprdl } \\
\text { for CHF }\end{array}$ & $\begin{array}{l}\text { syncope } \\
\text { syncope } \\
\text { syncope }\end{array}$ & $?$ & $\begin{array}{l}\text { mean } \\
-46\end{array}$ \\
\hline $\begin{array}{l}\text { Clel and (32) } \\
\text { ot al. }\end{array}$ & $\begin{array}{l}64 \\
61 \\
66\end{array}$ & $\begin{array}{l}\text { enalepril } \\
\text { for CHF } \\
\text { enalapr } 11 \\
\text { for CHF } \\
\text { enalapril } \\
\text { for CHf }\end{array}$ & $\begin{array}{l}\text { syncope } \\
\text { faintness } \\
\text { syncope }\end{array}$ & $\begin{array}{l}? \\
?\end{array}$ & $\begin{array}{l}-33 \\
-42 \\
-27\end{array}$ \\
\hline
\end{tabular}


as side effect of drugs not given because of hypertension; Cleland et a1.31,32 described patients with signs of cerebral ischaemia after an initial small dose of captopril $(6.25 \mathrm{mg})$ and enalapril (5-10 $\mathrm{mg}$ ) given because of heart failure. Especially patients with a high plasma renin activity may develop hypotension after captopri133.

\section{DISCUSSION}

Antihypertensive treatment has proved to reduce mortality and morbidity from cerebrovascular accidents $6-11$. It is common clinical practice to start drug treatment in elderly hypertensive patients with a diastolic blood pressure of $115 \mathrm{mmHg}$ or more, or with a diastolic pressure in the range $100-114 \mathrm{mmg}$ in the presence of complications or a systolic pressure greater than $180 \mathrm{mmH} 15,16$. However, it is still under discussion if and when the aged patient with milder hypertension and without organ damage should be treated. In any case, when deciding to start antihypertensive treatment in the elderly close attention must be qiven to side effects of antihyoertensive drugs.

This review reports the cases from literature with cerebral damage possibly due to drug-induced hypotension. In the young such events occur only after a marked blood pressure reduction with powerful agents such as diazoxide or nitroprusside. Normally the cerebral autoregulation protects the brain against blood pressure fluctuations; when blood pressure falls cerebral vessels dilate and when blood pressure rises they constrict, resulting in a constant cerebral blood flow in ranges of MAP from 60 to $150 \mathrm{~mm}$ g in the young 35 ; reduction of MAP by about $55 \%$ causes symptoms of cerebral hypoperfusion in this age group 36 . The finding of a pronounced shift upwards of the brain autoregulation curve in hypertensive patients signifies that blood pressure reduction must be gradual in these patients, because failure of autoregulation occurs at MAP levels higher than 60 $\mathrm{mmHg} 37$.

In the elderly signs of cerebral ischaemia may occur even after a rather small reduction in MAP. This may have several reasons. Firstly, in the aged the baroreflex is less sensitive, and a quick 


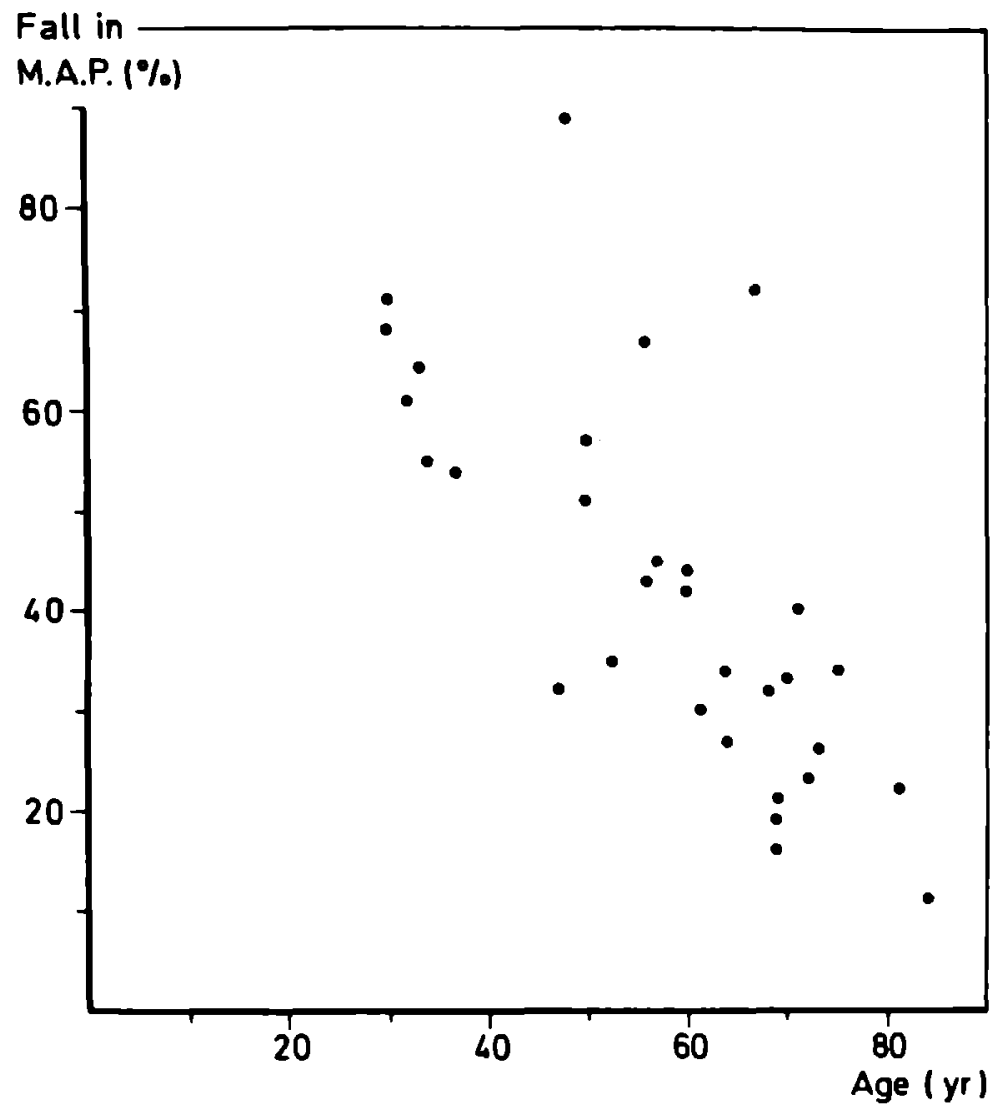

Fig. 1.

Drug-induced fall in MAP (\%) as a possible cause of cerebral ischaemia or stroke vs age in the reported patients from Table 1. 
fall in blood pressure cannot be compensated as promptly as in the young 38 . Secondly, in the elderly the cerebral autoregulation may be impaired; Wollner et al.39 studied seven elderly patients with postural hypotension and symptoms of cerebral ischaemia; the patients turned out to have unilateral or bilateral failure of cerebral autoregulation. The fall in MAP after a change in posture varied from $8 \%$ to 37\%; it was concluded that elderly patients with impaired cerebral autoregulation may be at risk of brain damage from minor falls in blood pressure. A third point of importance is a $25 \%$ reduction of cerebral blood flow in the aged as compared with the young 40 . Finally, in the presence of carotid vascular disease even a small reduction in blood pressure may cause cerebral ischaemia, as shown in a study by Ruff et al. 26 .

For all these reasons the elderly are especially at risk of developing cerebral ischaemia after a quick and marked fall in blood pressure: in this age group a reduction of MAP by far less than $55 \%$ can already induce cerebral ischaemia. This may be illustrated by Fig. 1 in which the fall in MAP and the age of the patients from Table I are put together (only patients of known age and with a known fall in MAP are represented in this figure).

Fortunately, not every elderly patient is at risk of developing cerebral ischaemia after blood pressure reduction; when autoregulation is not impaired, the carotid arteries are patent and cerebral blood flow and baroreflex sensitivity are only slightly diminished, a fall in MAP by less than 30-40\% would probably not induce cerebral ischaemia. Because in general practice it is not possible to study these parameters in every elderly patient with hypertension, it is advisable to start antihypertensive treatment in small doses, aiming at a gradual reduction of blood pressure. 


\section{REFERENCES}

1. Kannel WB, Wolf PA, Verter J, and MCNamara PM. Epidemiologic assessment of the role of blood pressure in stroke: The Framingham Study. JAMA 1970; 214 : 301-10.

2. Shekelle RB, Ostfeld AM, and Klawans HL. Hypertension and risk of stroke in an elderly population. Stroke 1974; $5: 71-5$.

3. Kannel WB, Wolf PA, MCGee DL, Dawber TR, McNamara P, and Castelli WP. Systolic blood pressure, arterial rigidity, and risk of stroke. The Framinghan Study. JAMA 1981; $245: 1225-9$.

4. Forette $F$, de 1 a Fuente $X$, Golmard J-L, Henry J-F, and Hervy M-P. The prognostic significance of isolated systolic hypertension in the elderly. Results of a ten year longitudinal survey. Clin Exp Hyp 1982; (A4)7 : 1177-91.

5. Colandrea MA, Friedman GD, Nichaman MZ, and Lynd CN. Systolic hypertension in the elderly. An epidemiological assessment. Circulation 1970; $41: 239-45$.

6. Amery $A$, Birkenhäger $W, B r i x k o ~ P$ et al. Mortality and morbidity results from the European Working Party on high blood pressure in the elderly trial. Lancet 1985; I : 1349-54.

7. Veterans Administration Cooperative Study Group on Ant ihypertensive Agents. Effects of treatment on morbidity in hypertension. III. Influence of age, diastolic pressure and prior cardiovascular disease; further analysis of side effects. Circulation 1972; 45 : 991-1004.

8. Hypertension Detection and Follow-up Program Cooperative Group. Five year findings of the hypertension detection and follow-up program. II. Mortality by race-sex and age. JAMA 1979; 242 : 2572-7.

9. Report by the Management Committee. The Australian therapeutic trial in mild hypertension. Lancet 1980; I : 1261-7.

10. Beevers DG, Fairman MJ, Hamilton M, and Harpur JE. Antihypertensive treatment and the course of established cerebrovascular disease. Lancet 1973; I : 1407-9.

11. Marshall J. A trial of long-term hypotensive therapy in cerebrovascular disease. Lancet 1964; I : 10-2. 
12. Hypertension-Stroke Cooperative Study Group. Effect of ant ihypertensive treatment on stroke recurrence. JAMA 1974; $229: 409-18$.

13. Carter $A B$. Hypertensive therapy in stroke survivors. Lancet 1970; I : 485-9.

14. WHO. Report of a WHO Exp Committee. Arterial hypertension. WHO Techn Rep Ser 1978; 628.

15. Franklin SS. Geriatric Hypertension, in: Samiy AH (ed) Clinical Geriatric Medicine, Med Clin of N Am, W.B. Saunders, Philadelphia 1983; 395-417.

16. O'Callaghan W, O'Brien E, O'Malley $K$. Hypertension in the elderly: epidemiology, pathophysiology and management in: O'Malley $K$ (ed) Clinical Pharmacology and drug treatment in the elderly, Churchill Livingstone, Edinburgh 1984; 122-138.

17. Hurwitz $H$. Predisposing factors in adverse reactions to drugs. $\mathrm{Br}$ Med J 1969; I : 536-9.

18. Ouslander JG. Drug therapy in the elderly. Ann Int Med 1981; 95 : 711-22.

19. Jansen PAF, Meyboom RHB, Schulte BPM, and Gribnau FWJ. Antihypertensive treatment as a possible cause of stroke in the elderly. Age Ageing 1986; 15 : 129-38.

20. Graham DI. Ischaemic brain damage of cerebral perfusion failure type after treatment of severe hypertension. $\mathrm{Br}$ Med J 1975; IV : 739.

21. Jackson G, Mahon W, Pierscianowski TA, and Condon J. Inappropriate antihypertensive therapy in the elderly. Lancet 1976; II : 1317-8.

22. Kumar GK, Dastoor FC, Robayo JR, and Razzaque MA. Side effects of diazoxide. JAMA 1976; $235:$ 275-6.

23. Cove $D H$, Seddon $M$, Fletcher RF, and Dukes $D C$. Blindness after treatment for malignant hypertension. Br Med J 1979; II : 245-6.

24. Ledingham JGG, and Rajagopalan B. Cerebral complications in the treatment of accelerated hypertension. Q J Med 1979; 48 : 25-41.

25. Phillips MS, and Jones JV. Emergency treatment of high blood pressure with oral atenolol. (Letter) Br Med J 1981; 283 : 58. 
26. Ruff RL, Talman WT, and Petito F. Transient ischaemic attacks associated with hypotension in hypertensive patients with carotid artery stenosis. Stroke 1981; 12 : 353-5.

27. Hodsman GP, Isles CG, Murray GD, Usherwood TP, Webb OJ, and Robertson JIS. Factors related to first dose hypotensive effect of captopril: prediction and treatment. Br Med J 1983; 286 : 832-4.

28. Pitlik S, Manor RS, Lipshitz I, Perry G, and Rosenfeld $J$. Transient retinal ischaemia induced by nifedipine. Br Med J 1983; 287 : 1845-6.

29. Haas DC, Streeten DHP, Kim RC, Naalbandian AN, and Obeid AI. Death from cerebral hypoperfusion during nitroprusside treatment of acute angiotensin-dependent hypertension. Am J Med 1983; 75 : 1071-6.

30. Strandgaard S, Andersen GS, Ahigreen P, and Nielsen PE. Visual disturbances and occipital brain infarct following acute, transient hypotension in hypertensive patients. Acta Med Scand 1984; 216 : 417-22.

31. Cleland J, Semple P, Hodsman P, Ball S, Ford I, and Dargie H. Angiotensin II levels, hemodynamics, and sympathoadrenal function after low-dose captopril in heart failure. Am J Med 1984; 77 : 880-6.

32. Cleland JGF, Dargie HJ, MCAlDine $H$ et al. Severe hypotension after first dose of enalapril in heart failure. $\mathrm{Br}$ Med $\mathrm{J} 1985$; 291 : 1309-12.

33. Labarre TR, O'Connell JB, Gunnar RM. Captopril therapy for severe CHF: hypotensive response in presence of markedly elevated PRA. (Letter) Am Heart J 1982; 103 : 308-10.

34. Adams JH, Brierley B, Connor RCR, and Treip CS. The effects of systemic hypotension upon the human brain, clinical and neuropathological observations in 11 cases. Brain 1966; 89 : 235-80.

35. Johnson RH, Lambie DG, and Spalding JMK (eds) Neurocardiology. The interrelationship between dysfunction in the nervous and cardiovascular systems. WB Saunders, London 1984; 261-322. 
36. Strandgaard S. Autoregulation of cerebral blood flow in hypertensive patients. The modifying influence of prolonged antihypertensive treatment on the tolerance to acute, drug-induced hypotension. Circulation 1976; $53: 720-7$.

37. Strandgaard S, Olesen J, Skinhøj E, Lassen NA. Autoregulation of brain circulation in severe arterial hypertension. Br Med $\mathrm{J}$ 1973; I : 507-510.

38. Gribbin B, Pickering TG, Sleight $P$, and Peto R. Effect of age and high blood pressure on baroreflex sensitivity in man. Circulation Res 1971; 29 : 424-31.

39. Wollner L, MCCarthy SI, Soper NDW, and Macy DJ. Failure of cerebral autorequiation as a cause of brain dysfunction in the elderly. Br Med J 1979; I : 1117-8.

40. Davis SM, Ackerman RH, Correia JA et al. Cerebral blood flow and cerebrovascular $\mathrm{CO}_{2}$ reactivity in stroke-age normal controls. Neurology 1983; 33 : 391-9. 


\section{ANTIHYPERTENSIVE TREATMENT AS A POSSIBLE \\ CAUSE OF STROKE IN THE ELDERLY}

P.A.F. Jansen, B.P.M. Schulte, R.H.R. Meyboom, F.W.J. Gribnau

published in

Age and Ageing 1986; $15: 129-138$ 


\section{SUMMARY}

There have been a few reports on stroke as a side-effect of antihypertensive treatment. To study the occurence of this side-effect, a questionnaire was sent to all Dutch nursing homes ( $n=322)$. Thirty patients were reported with signs of cerebral ischaemia shortly after starting antihypertensive and diuretic drugs. Nine of these cases were well documented with full data on blood pressure, measured immediately after the event and compared with pretreatment levels.

A review of cases reported in the literature is presented.

It is concluded that, especially in elderly patients, an abrupt fall in blood pressure may induce cerebral ischaemia, sometimes resulting in stroke. Antihypertensive treatment in the elderly should therefore start with a small dose, the aim being to reduce blood pressure gradual iv. 
INTRODUCTION

The beneficial effects of antihypertensive treatment in the prevention of stroke are well established. Among the side-effects of the drugs used for this indication, reports in the literature paradoxically mention signs of cerebral ischaemia, stroke and visual impairment1-13. In an attempt to gather information on the extent of the problem of antihypertensive or diuretic treatment as a contributing factor to cerebral ischaemia or stroke, a questionnaire was sent to all Dutch nursing homes, as it was assumed that the type of patients concerned might be found within the population of nursing-home patients.

\section{MATFRIALS AND METHODS}

A questionnaire was sent to all medical directors of Dutch nursing homes $(n=322)$. The following questions were posed:

- Do you know of patients suffering from (ir)reversible focal cerebral deficit, presented shortly after starting medication with furosemide;

- other diuretics

- beta-blocking drugs

- vasodilators

- methyldopa

- others

- combinations

- If so, is the patient

- under your treatment

- discharged

- deceased

Stroke is defined as rapidly developing clinical sians of focal disturbance of cerebral function lasting more than 24 hours or leading to death, with no apparent cause other than a vascular origin, as used by the WHO14.

The term 'signs of cerebral ischaemia' is used for all clinical symptoms apparently due to impaired cerebral perfusion, reversible within 24 hours. 
erom the reported cases all available data were collected by way of correspondence or telephone. From this information, the interval between the start of antihypertensive or diuretic treatment and the development of signs of cerebral ischaemia or stroke was noted. The difference in blood pressure measured before treatment and directly after stroke (or during cerebral ischaemia), was expressed as change in mean arterial pressure ( $\triangle M A P)$ and calculated according to the equation:

$$
\begin{aligned}
\text { MAP } & =\text { diastolic pressure }+1 / 3 \text { (systolic-diastolic pressure) } \\
\triangle M A P & =\frac{\text { MAP after stroke }- \text { MAP before treatment }}{\text { MAP before treatment }} \times 100 \%
\end{aligned}
$$

\section{RESULTS}

The questionnaire was completed and returned by 177 (55\%) physicians, of whom 25 reported 30 patients with sians of cerebral ischaemia or stroke developing within two weeks of the start of antihypertensive or diuretic treatment (Table 1). Twenty-two patients suffered a stroke; the other eight patients showed signs of cerebral ischaemia: drowsiness, dizziness, collapse, and in one a seizure of vascular origin occurred. Nine patients were still in the nursing home, nine

TABLE I

30 REPORTED CASES WITH SIGNS OF CEREBRAL ISCHAEMIA OR STROKE WITHIN TWO WEEKS OF THE START OF ANTIHYPERTENSIVE OR DIURETIC TREATMENT

\begin{tabular}{llll}
\hline medication & indication & $n$ & signs \\
\hline furosemide & heart failure & 9 & stroke (7) ischaemia(2) \\
furosemide & hypertension & 2 & stroke $(1)$ ischaemia(1) \\
furosemide & renal insufficiency & 1 & stroke \\
methyldopa & hypertension & 9 & stroke(9) \\
Dyta-urese & hypertension & 3 & ischaemia(3) \\
mefruside & hypertension & 1 & stroke \\
metoprolol & hypertension & 1 & stroke \\
atenolol & hypertension & 1 & ischaemia \\
labetalol & hypertension & 1 & stroke \\
prazosin & hypertension & 1 & stroke \\
clonidine & hypertension & 1 & ischaemia \\
\hline
\end{tabular}


TABLE II. DATA AND BLOOD PRESSURE (BP; mmHg) COURSE IN 9 PAIIENTS ( $F=$ female, $M=$ male)

\begin{tabular}{|c|c|c|c|c|c|c|c|c|}
\hline $\begin{array}{l}\text { AGE (yr) } \\
\text { gender }\end{array}$ & MEDICATION & $\begin{array}{l}\text { NEWLY INS IALLED } \\
\text { DRUG (SINCE) }\end{array}$ & INDICAIION & $\begin{array}{l}\text { BP BEF ORE } \\
\text { TREATMENT }\end{array}$ & $\begin{array}{l}\text { BP AF IER STROKE } \\
\text { OR DUR ING ISCHEMIA }\end{array}$ & MMAP & SIGNS & COURSE \\
\hline $\begin{array}{l}77 \\
F\end{array}$ & Dyta-urese ${ }^{R}$ & $\begin{array}{l}\text { methyldope } \\
\text { (hours) } \\
2 \times 250 \mathrm{mg}\end{array}$ & hypertension & $230 / 120$ & $190 / 100$ & $-17 \%$ & $\begin{array}{l}\text { cerebellar } \\
\text { infarction }\end{array}$ & $\begin{array}{l}\text { partly recovered } \\
\text { after cessation of } \\
\text { Dyta-Urege }{ }^{R} \text { and } \\
\text { methyldopa }\end{array}$ \\
\hline $\begin{array}{l}67 \\
F\end{array}$ & Indapam 1 de & $\begin{array}{l}\text { labetalol } \\
(2 \text { days }) \\
3 \times 200 \mathrm{mq}\end{array}$ & hypertension & $210 / 120$ & $160 / 80$ & $-29 \%$ & $\begin{array}{l}\text { hemispher 1c } \\
\text { infarction }\end{array}$ & no recovery \\
\hline $\begin{array}{l}76 \\
F\end{array}$ & $\begin{array}{l}\text { methyldopa } \\
\text { metoprolol } \\
\text { furosemide }\end{array}$ & $\begin{array}{l}\text { prazosin } \\
\text { (hours) } \\
2 \times 0.5 \mathrm{mg}\end{array}$ & hypertension & $240 / 130$ & $190 / 80$ & $-30 \%$ & $\begin{array}{l}\text { hemispher ic } \\
\text { infarct ion }\end{array}$ & no recovery \\
\hline $\begin{array}{l}79 \\
M\end{array}$ & - & $\begin{array}{l}\text { furosem } 1 \text { de } \\
\text { ( } 7 \text { days) } \\
1 \times 40 \mathrm{mg}\end{array}$ & hypertension & $210 / 130$ & $140 / 90$ & $-32 \%$ & $\begin{array}{l}\text { drowsy } \\
\text { fainting }\end{array}$ & $\begin{array}{l}\text { recovery } \\
\text { after cessation } \\
\text { of furosemide }\end{array}$ \\
\hline $\begin{array}{l}74 \\
M\end{array}$ & Dytenzide ${ }^{R}$ & $\begin{array}{l}\text { metoprolol } \\
\text { (hours) } \\
1 \text { dd } 100 \mathrm{mg}\end{array}$ & hypertension & $240 / 130$ & $150 / 90$ & $-34 \%$ & $\begin{array}{l}\text { hemispheric } \\
\text { infarction }\end{array}$ & $\begin{array}{l}\text { recovery after } \\
\text { cessation } \\
\text { metoprol ol }\end{array}$ \\
\hline $\begin{array}{l}71 \\
M\end{array}$ & metoprolol & $\begin{array}{l}\text { mefruelde } \\
(12 \text { days }) \\
1 \times 25 \mathrm{mg}\end{array}$ & hypertension & $200 / 120$ & 110/80 & $-36 \%$ & $\begin{array}{l}\text { hemispher 1c } \\
\text { infarction }\end{array}$ & $\begin{array}{l}\text { partly recover- } \\
\text { ed after cessa- } \\
\text { tion mefruside }\end{array}$ \\
\hline $\begin{array}{l}73 \\
M\end{array}$ & - & $\begin{array}{l}\text { atenolol } \\
(2 \text { days }) \\
1 \times 100 \mathrm{mg}\end{array}$ & hypertension & $220 / 120$ & $130 / 70$ & $-41 \%$ & $\begin{array}{l}\text { confusion } \\
\text { collapse }\end{array}$ & $\begin{array}{l}\text { recovery after } \\
\text { cessation } \\
\text { atenolol }\end{array}$ \\
\hline $\begin{array}{l}85 \\
M\end{array}$ & - & $\begin{array}{l}\text { furosem1de } \\
\text { (2 days) } \\
200 \mathrm{mg} \text { totel }\end{array}$ & heart fallure & $240 / 140$ & $120 / 65$ & $-52 \%$ & $\begin{array}{l}\text { hem ispheric } \\
\text { infarction }\end{array}$ & no recovery \\
\hline $\begin{array}{l}75 \\
M\end{array}$ & & $\begin{array}{l}\text { methyldopa } \\
(7 \text { days) } \\
2 \times 250 \mathrm{mg} \\
\text { and Dyta-Urese } \\
(7 \text { days }) 1 \times 1\end{array}$ & hypertension & $190 / 120$ & $80 / 60$ & $-53 \%$ & $\begin{array}{l}\text { hemispher ic } \\
\text { infarction }\end{array}$ & no recovery \\
\hline
\end{tabular}


had been discharged and twelve had died. Personal data (sex, age) were not available in nine cases. The other 21 were 12 women and 9 men with a mean age of $77.6 \pm 8.4$ years.

Detailed data on the course of blood pressure were available on 8 patients with antihypertensive treatment and one receiving a loop diuretic because of heart failure (Table II).

The patient aged 77 , started with Dyta-Urese ${ }^{R}$ for hypertension. Rlood pressure was measured after a few days of treatment and although signs of cerebral ischaemia were present (fainting), methyldopa was added and stroke occurred. At that time no blood pressure figures were recorded. In six patients who were already using antihypertensive medication, the event occurred shortly after addition of one more ant ihypertensive drug.

All these patients had severe hypertension. Pretreatment systolic pressure ranged from 190 to 240 (mean 220) $\mathrm{mm} H \mathrm{Hg}$ and diastolic pressure from 120 to 140 (mean 126) $\mathrm{mmHg}$. The systolic pressure firstrecorded during signs of cerebral ischaemia or after stroke ranged from 80 to 190 (mean 141) $\mathrm{mmHg}$ and diastolic pressure from 60 to 100 (mean 79) $\mathrm{mmHg}$. The fall in MAP varied from 17 to 53\%. There was partial or complete recovery after cessation of therapy in five of the nine patients.

\section{DISCUSSION}

High blood pressure is a powerful contributor to cardio- and cerebrovascular disease15-18, in the elderly also19-21. Several studies have shown that antihypertensive treatment reduces mortality and morbidity22-25. However, there is no consensus about the level above which antihypertensive treatment should be started. The most widely accepted definition of hypertension, that of the WHO, is a systolic pressure of $160 \mathrm{mmHg}$ or higher and/or a diastolic pressure of $95 \mathrm{mmHg}$ or nigher26. However, this definition does not take age into account. In the study of the European Working Party on High Blood Pressure in the Elderly, treatment was started above $160 \mathrm{mmHg}$ systolic and $90 \mathrm{mmHg}$ diastolic 22 . Others have defined ranges for treatment of elderly hypertensives: a diastolic pressure of $100-110 \mathrm{mmHg}$ 
$110 \mathrm{mmHg}$ in the presence of complications or a systolic pressure above $180 \mathrm{~mm}^{27}$. There is general agreement that a diastolic blood pressure above $115 \mathrm{mmHg}$ requires treatment in any age category. It is of course no matter of discussion that the patients described in Table II needed antihypertensive treatment.

In the elderly especially, hypertension should be treated with caution for several reasons. Firstly, in the aged the baroreflex is less sensitive, and a quick fall in blood pressure cannot be compensated immediately as in the young 28 .

A second point of importance is cerebral autoregulation. The brain is protected against blood pressure fluctuations by autoregulation. When blood pressure falls, cerebral vessels dilate; when blood pressure rises, they constrict, resulting in a constant cerebral blood flow in MAP ranges from 60 to $150 \mathrm{~mm}$ in normal individuals. The brain of a patient with chronic hypertension is more vulnerable to hypotension because the cerebral autoregulatory curve shifts upwards: in these patients a reduction of cerebral blood flow occurs at a higher MAP than in normotensives 29 . A reduction in MAP of about $25 \%$ is required to reach the lower limit of cerebral blood flow autorequiation; a further reduction to about $55 \%$ is needed to cause symptoms of brain hypoperfusion in both hypertensive and normotensive subjects under the age of 66 years 30 . In the elderly - even in the absence of hypertension - cerebral autoregulation can be impaired 31 .

In the early 1950s an inverse correlation was demonstrated between cerebral blood flow oer se and age with a reduction of about $25 \%$ in the aged as compared with the young ${ }^{32}$. In later years this finding was confirmed by other authors using more modern methods 33,34 .

Another important factor in cerebral blood flow is the haematocrit: flow is lower with a high haematocrit (over 0.46)35. However, regulatory mechanisms can maintain normal cerebral oxygen transport despite increased plasma and whole blood viscosity 36.

It might have been expected that atherosclerosis would be an important factor in lowering the flexibility of brain arteries, patients with the most pronounced arteriosclerosis being the most endangered 
for stroke in the event of a hypotensive episode. Several studies, however, do not support this concept37,38. Torvik and Skullerud studied 115 cases with cardiac arrest and found no correlation between the degree of arteriosclerosis and the risk for brain infarcts as a complication of the hypotensive episode 38 . A relationship between the morphological substrate and the outcome of a period of hypotension does exist, as shown by the neuropathological observations of Adams et al. in 11 patients ${ }^{39}$; the necrosis of grey and white matter at the boundary zones ("watersheds") appeared to be attributable to a precipitous reduction in systemic blood pressure, while diffuse alterations seemed to be the result of a moderate but sustained systemic hypotension.

In a retrospective study of post-mortems, fatal strokes in elderly patients often appeared to be due to acute hypotension caused by events such as heart failure, occult haemorrhage, or multiple pulmonary embolism13.

There are several reports in the literature of cerebral ischaemia, stroke and visual impairment as side effects of antihypertensive treatment; these reports are listed in Table III.

TABLE III. CASES OF CEREBRAL ISCHAEMIA OR STROKE, INDUCED BY HYPOTENSION, FROM THE LI TERATURE

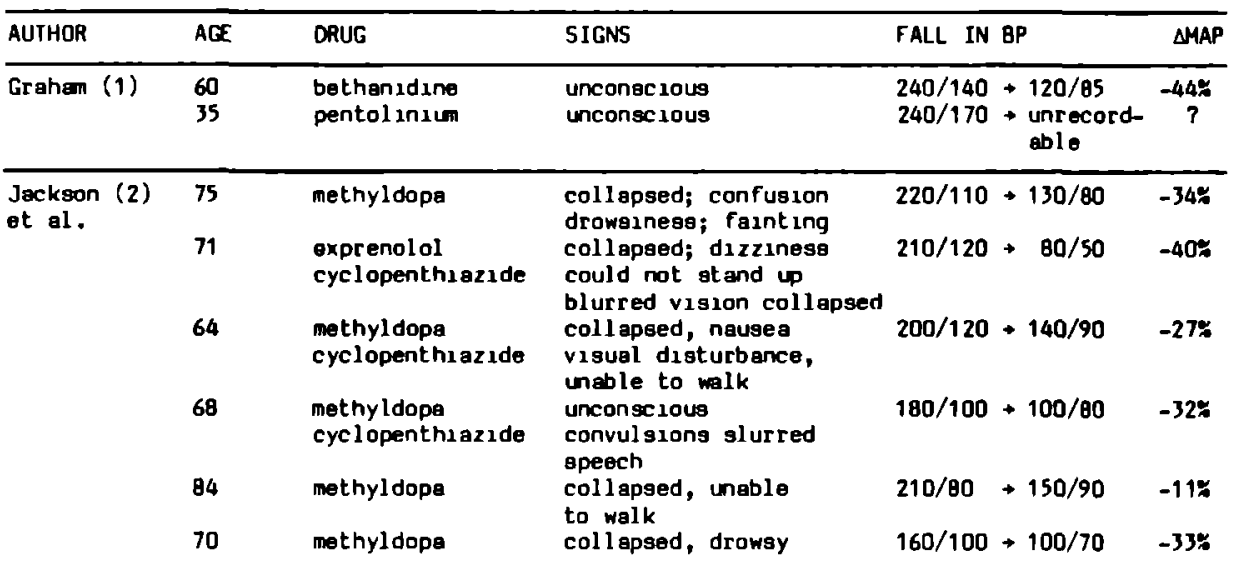




\begin{tabular}{|c|c|c|c|c|c|c|}
\hline $\begin{array}{l}\text { Cove (4) } \\
\text { et al. }\end{array}$ & 30 & $\begin{array}{l}\text { methyldopa } \\
\text { diazaxide } \\
\text { furosem ide } \\
\text { atenolol }\end{array}$ & $\begin{array}{l}\text { confused } \\
\text { bl indness } \\
\text { bl indness }\end{array}$ & $\begin{array}{l}270 / 175 \\
250 / 170\end{array}$ & $\begin{array}{l}+100 / 50 \\
+\quad 90 / 70\end{array}$ & $\begin{array}{l}-68 \% \\
-61 \%\end{array}$ \\
\hline \multirow[t]{10}{*}{$\begin{array}{l}\text { Ledingham } \\
\text { et al. (s) }\end{array}$} & 60 & $\begin{array}{l}\text { diazoxide } \\
\text { propranolol } \\
\text { furosemide }\end{array}$ & $\begin{array}{l}\text { confused } \\
\text { dysphasic }\end{array}$ & $240 / 155$ & $\rightarrow 130 / 90$ & $-42 \%$ \\
\hline & 57 & $\begin{array}{l}\text { diezoxide } \\
\text { hydralazine }\end{array}$ & $\begin{array}{l}\text { unconscious } \\
\text { poor vision }\end{array}$ & $220 / 155$ & $\rightarrow 130 / 80$ & $-45 \%$ \\
\hline & 30 & $\begin{array}{l}\text { diazoxide } \\
\text { promazine }\end{array}$ & $\begin{array}{l}\text { convulgion } \\
\text { unconsclous }\end{array}$ & $220 / 145$ & $\rightarrow \quad 70 / 40$ & $-71 x$ \\
\hline & 56 & drazoxide & $\begin{array}{l}\text { reep, arrest, ofter } \\
\text { resugcitation choreo- } \\
\text { athetogis }\end{array}$ & $230 / 130$ & $+80 / 40$ & $-67 \%$ \\
\hline & 64 & $\begin{array}{l}\text { diezaxide } \\
\text { regerpine }\end{array}$ & $\begin{array}{l}\text { unconscious } \\
\text { cardlac arregt }\end{array}$ & $240 / 130$ & $\rightarrow 150 / 90$ & $-34 \%$ \\
\hline & 48 & $\begin{array}{l}\text { chlorpromazine } \\
\text { diazoxide } \\
\text { methyldopa }\end{array}$ & $\begin{array}{l}\text { unconscious } \\
\text { deceased }\end{array}$ & $300 / 160$ & $+70 /-$ & $-89 \%$ \\
\hline & 33 & $\begin{array}{l}\text { diazoxide } \\
\text { hydral azine } \\
\text { tr ime taphan }\end{array}$ & $\begin{array}{l}\text { unconsc } 10 u s \\
\text { hemiplegla }\end{array}$ & $250 / 150$ & $\rightarrow \quad 80 / 60$ & $-64 \%$ \\
\hline & 56 & $\begin{array}{l}\text { hydralazine } \\
\text { amiloride } \\
\text { propranolol }\end{array}$ & $\begin{array}{l}\text { drowsy } \\
\text { disoriented } \\
\text { meakness of left } \\
\text { side of face }\end{array}$ & $210 / 150$ & $\rightarrow 130 / 80$ & $-43 \%$ \\
\hline & 50 & $\begin{array}{l}\text { diazoxide } \\
\text { hydralazine } \\
\text { propranolol }\end{array}$ & $\begin{array}{l}\text { droway } \\
\text { fixed and dilated } \\
\text { pupils }\end{array}$ & $210 / 170$ & $+120 / 75$ & $-51 \%$ \\
\hline & 34 & $\begin{array}{l}\text { dlazoxide } \\
\text { hydralazine } \\
\text { propranolol } \\
\text { bethanidine } \\
\text { prochloorperazine }\end{array}$ & $\begin{array}{l}\text { drowsy } \\
\text { confusion }\end{array}$ & $250 / 140$ & $\rightarrow 100 / 70$ & $-55 \%$ \\
\hline $\begin{array}{l}\text { Pitlik (6) } \\
\text { et al. }\end{array}$ & 67 & nifedipine & $\begin{array}{l}\text { blindness } \\
\text { retinel ischaemia }\end{array}$ & $?$ & $+110 / 70$ & $?$ \\
\hline $\begin{array}{l}\text { Phall1ps } \\
\text { ot al. (7) }\end{array}$ & 50 & atenolol & $\begin{array}{l}\text { hemiparesis } \\
\text { decersed }\end{array}$ & $240 / 140$ & $\rightarrow 135 / 80$ & $-57 \%$ \\
\hline \multirow[t]{2}{*}{$\begin{array}{l}\text { Strandgaard } \\
\text { ot al (B) }\end{array}$} & 47 & $\begin{array}{l}\text { furosemide } \\
\text { chloorpromazine }\end{array}$ & $\begin{array}{l}\text { visual impairment } \\
\text { infarction }\end{array}$ & $240 / 130$ & $\rightarrow 180 / 90$ & $-32 \%$ \\
\hline & 61 & $\begin{array}{l}\text { furosemide } \\
\text { chloorpromazine }\end{array}$ & $\begin{array}{l}\text { visual } \\
\text { impasrment }\end{array}$ & $180 / 100$ & $+105 / 80$ & $-30 \%$ \\
\hline $\begin{array}{l}\text { Kumar (9) } \\
\text { et al. }\end{array}$ & 63 & diazoxide & hem 1pleg1a & $290 / 160$ & $+230 / 130$ & $-20 \%$ \\
\hline $\begin{array}{l}\text { Haas (10) } \\
\text { et al. }\end{array}$ & 37 & $\begin{array}{l}\text { propranolal } \\
\text { nitroprusside }\end{array}$ & $\begin{array}{l}\text { fainting, blindness } \\
\text { lethergic, confuged } \\
\text { deceased }\end{array}$ & $220 / 120$ & $+110 / 50$ & $-54 \%$ \\
\hline Coppeto (11) & 78 & timolol ocgtt. & visual impairment & $?$ & $\rightarrow 135 / 60$ & $?$ \\
\hline
\end{tabular}




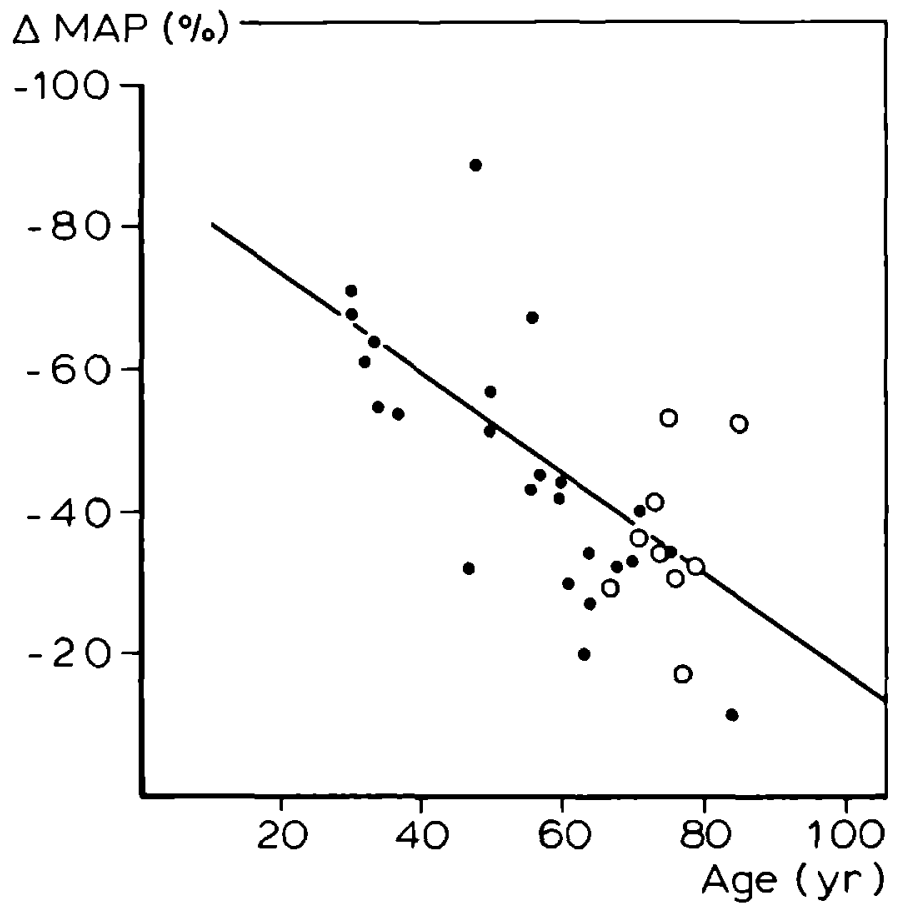

Fig. 1.

Relationship between fall in MAP after start of antihypertensive/ diuretic treatment (resulting in signs of cerebral ischaemia or stroke) and age of 9 patients presented in this paper (open circles) and 24 patients reported in the literature (solid circles).

The Figure shows the $\triangle M A P$ values from this selection of the literature and from our patients, as described in Table II. They illustrate the greater vulnerability of the brain with increasing age. The present data are in agreement with the findings of others that all kinds of antihypertensive or diuretic drugs may contribute to the development of cerebral ischaemia or even stroke when blood pressure is lowered too quickly. The conclusion of our study, based on a small collection of epidemiological data, needs further substantiation. In this study we were unable to obtain information about the number of 
inappropriately treated patients, who did not develop symptoms. In another study we collected data on 100 patients admitted for stroke in a community hospital, with particular reference to changes in blood pressure and on recent medication history.

It is advisable to start antihypertensive treatment, especially in the elderly, with a small dose; the aim being to reduce blood pressure gradually. Drugs like the high-ceiling loop diuretic furosemide are best avoided in the treatment of hypertension, because of their powerful hypovolaemic action with the risk of a quick fall of blood pressure. In the treatment of heart failure with furosemide, blood pressure control is needed.

In conclusion, when starting antihypertensive treatment in the aqed one should be aware that inaccurate, i.e. too quick or too marked, reduction of blood pressure may induce stroke. We therefore advocate a cautious approach in the treatment of high blood pressure, with appropriate drugs, especially in the elderly. 


\section{REFERENCES}

1. Graham $\mathrm{nI}$. Ischaemic brain damage of cerebral perfusion failure type after treatment of severe hypertension. Br Med J 1975; IV : 739.

2. Jackson G, Mahon W, Pierscianowski TA, and Condon J. Inappropriate antihypertensive therapy in the elderly. Lancet 1976; II : 1317-8.

3. Editorial. Dangerous antihypertensive treatment. Br Med J 1979; II : 228-9.

4. Cove $D H$, Seddon $M, F l e t c h e r ~ R F$, and Dukes DC. Blindness after treatment for malignant hypertension. Br Med J 1979; II : 246-6.

5. Ledingham JGG, and Rajagopalan B. Cerebral complications in the treatment of accelerated hypertension. Q J Med 1979; 48 : 25-41.

6. Pitlik S, Manor RS, Lipshitz I, Perry G, and Rosenfeld J. Transient retinal ischaemia induced by nifedipine. Br Med $\mathrm{J}$ 1983; 287 : 1845-6.

7. Phillips MS, and Jones JV. Emergency treatment of high blood pressure with oral atenolol. (Letter) $\mathrm{Br}$ Med J 1981; 283 : 58.

8. Strandgaard S, Andersen GS, Ahlgreen P, and Nielsen PE. Visual disturbances and occipital brain infarct following acute, transient hypotension in hypertensive patients. Acta Med Scand $1984 ; 216: 417-22$.

9. Kumar GK, Dastoor FC, Robayo JR, and Razzaque MA. Side effects of diazoxide. JAMA 1976; $235:$ 275-6.

10. Haas DC, Streeten DHP, Kim RC, Naalbandian AN, and Obeid AI. Death from cerebral hypoperfusion during nitroprusside treatment of acute angiotensin-dependent hypertension. Am J Med 1983; 75 : 1071-6.

11. Coppeto JR. Transient ischemic attacks and amaurosis fugax from timolol. Ann 0phthalmol 1985; $17: 64-5$.

12. Ross Russell RW, and Page NGR. Critical perfusion of brain and retina. Brain 1983; $106: 419-34$.

13. Mitchinson MJ, The hypotensive stroke. Lancet 1980; 1 : 244-6.

14. Hatano S. Control of stroke in the community - methodological considerations and protocol of WHO stroke Register. Working docu- 
ment for meeting on community control of stroke and hypertension, Geneva 6-13 December 1973 (WHO document no. r.VD/S/73.6 Rev. 1).

15. Kannel WB. Role of blood pressure in cardiovascular morbidity and mortality. Prog Cardiovasc Dis 1974; 17 : 5-24.

16. Kannel WB, Wolf PA, Verter $J$, and McNamara PM. Epidemiologic assessment of the role of blood pressure in stroke: The Framingham Study. JAMA 1970; 214 : 301-10.

17. Hypertension Detection and Follow-up Program Cooperative Group. Five year findings of the hypertension detection and follow-up program. I. Reduction in mortality of persons with high blood pressure, including mild hypertension. JAMA 1979; 242 : 2562-71.

18. Kannel WB, Wolf PA, McGee DL, Dawber TR, MCNamara P, and Castelli WP. Systolic blood pressure, arterial rigidity, and risk of stroke. The Framingham study. JAMA 1981; 245 : 1225-9.

19. Shekelle RB, Ostfeld AM, and Klawans HL. Hvpertension and risk of stroke in an elderly population. Stroke $1974 ; 5: 1-5$.

20. Forette $F$, de la Fuente $X$, Golmard $J-L$, Henry J-F, and Hervy $M-P$. The proqnostic significance of isolated svstolic hypertension in the elderly. Results of a ten year longitudinal survey. Clin Exp Hyp 1982; (A4)7 : 1177-91.

21. Colandrea MA, Friedman GD, Nichaman MZ, and Lynd CN. Systolic hypertension in the elderly. An epidemioloqical assessment. Circulation 1970; $41: 239-45$.

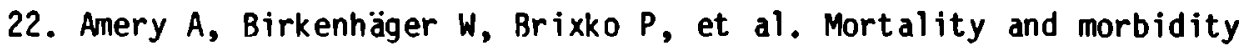
results from the European Working Party on high blood pressure in the elderly trial.Lancet 1985; I : 1349-54.

23. Veterans Administration Cooperative Study Group on Antihypertensive Agents. Effects of treatment on morbidity in hypertension. III. Influence of age, diastolic pressure and prior cardiovascular disease; further analysis of side effects. Circulation 1972; 45 : 991-1004.

24. Hypertension Detection and Follow-up Program Cooperative Group. Five year findings of the hypertension detection and follow-up program. II. Mortality by race-sex and age. JAMA 1979; 242 : 2572-7. 
25. Report by the Management Committee. The Australian therapeutic trial in mild hypertension. Lancet 1980; I : 1261-7.

26. WHO, Report of a WHO Exp Comittee, Arterial hypertension. WHO Techn Rep Ser 1978; 628.

27. O'Callaghan $W, O^{\prime B r i e n} E$, and O'Malley $K$. Hypertension in the elderly: epidemiology, pathophysiology and management. $K$ O'Malley (ed) in: Clinical pharmacology and drug treatment in the elderly, Churchill Livinastone, Edinburgh 1984; 122-38.

28. Gribbin B, Pickering TG, Sleight $P$, and Peto R. Effect of age and high blood pressure on baroreflex sensitivity in man. Circulation Res 1971; 29 : 424-31.

29. Strandgaard S, Olesen J, Skinhoj E, and Lassen NA. Autoregulation of brain circulation in severe arterial hypertension. $\mathrm{Br}$ Med $\mathrm{J}$ 1973; I : 507-10.

30. Strandgaard S. Autoregulation of cerebral blood flow in hypertensive patients. The modifying influence of prolonged antihypertensive treatment on the tolerance to acute, drug-induced hypotension. Circulation 1976; $53: 720-7$.

31. Wollner L, MCCarthy ST, Soper NDW, and Macy DJ. Failure of cerebral autorequlation as a cause of brain dysfunction in the elderly. Br Med J 1979; I : 1117-8.

32. Kety SS. Human cerebral blood flow and oxygen consumption as related to aging. J Chron Dis $1956 ; 3: 478-86$.

33. Thomas DJ, Zilkha $E$, Redmond $S$ et al. An intravenous ${ }^{153}$ xenonclearance technique for measuring cerebral blood flow. J Neurol Sci $1979 ; 40: 53-63$.

34. Davis SM, Ackerman RH, Correia JA et al. Cerebral blood flow and cerebrovascular $\mathrm{CO}_{2}$ reactivity in stroke-age normal controls. Neurology 1983; 33 : 391-9.

35. Thomas DJ, Marshall J, Ross Russell RW et al. Effect of haematocrit on cerebral blood-flow in man. Lancet 1977; II : 941-3.

36. Brown MM, and Marshall J. Regulation of cerebral blood flow in response to changes in blood viscosity. Lancet 1985; I : 604-9. 
37. Kendell RE, and Marshall J. Role of hypotension in the genesis of transient focal cerebral ischaemic attacks. Br Med J 1963; II : 344-8.

38. Torvik A, and Skullerud K. How often are brain infarcts caused by hypotensive episodes? Stroke 1976; $7: 255-7$.

39. Adams JH, Brierley B, Connor RCR, and Treip CS. The effects of systemic hypotension upon the human brain, clinical and neuropathological observations in 11 cases. Brain 1966; $89: 235-80$. 
CASE HISTORIES

Case I

A woman aged 77 years, with known hypertension, atrial fibrillation and heart failure, was treated with Dyta-Urese ${ }^{R}$ one capsule daily, resulting in weight loss from 87 to $80 \mathrm{~kg}$ in a few days and a fall in blood pressure from $230 / 120$ to $190 / 100 \mathrm{mmHg}$. In view of a propensity to collapse she was admitted to hospital. Methyldopa $(2 \times 250 \mathrm{mg})$ was added to the therapy and thereupon the patient suffered from disturbances of equilibrium and became aphasic. Blood pressure was not recorded at that time. A cerebral CAT-scanning showed cerebellar infarction. After 6 weeks the patient was transferred to a nursing home. She was drowsy and aphasic. Blood pressure was 120/80 $\mathrm{mmHg}$ and blood urea was $27.4 \mathrm{mmol} / 1$. After the cessation of Dyta-urese $R$ and methyldopa the blood pressure rose to $170 / 105 \mathrm{mmHg}$ and the blood urea decreased to $5.1 \mathrm{mmol} / 1$ (in the normal range). The patient improved: the neurological disturbances (vertigo, ataxia and aphasia) persisted.

\section{Case II}

A woman aged 67 years used indapamide once daily for two weeks because of recently detected hypertension (earlier blood pressure level $170 / 90 \mathrm{mmHg}$ ). A blood pressure of $210 / 120 \mathrm{mmHg}$ was recorded and labetalol ( $3 \times 200 \mathrm{mg}$ ) was added to the treatment. After 2 days the patient developed stroke and was admitted to hospital. Rlood pressure at admission was $160 / 80 \mathrm{mmH}$. An infarction in the area of the right middle cerebral artery was diaanosed. After a few weeks she was transferred to a nursing home. There was no recovery from the leftsided hemiparesis.

Case III

A woman aged 76 years had been treated for hypertension over a long period; last treatment consisted of a combination of metoprolol, methyldopa and furosemide. Nevertheless, blood pressure was still high $(240 / 130 \mathrm{mmHg})$ and prazosin $0.5 \mathrm{mg}$ twice daily was added to the treatment. On the same day the patient developed left-sided hemipare- 
sis. At admission the blood pressure was $190 / 80 \mathrm{~mm}$. Cerebral CATscanning showed an infarction in the area of the right middle cerebral artery. Prazosin, methyldopa and metoprolol were stopped. The patient was transferred to a nursing home. There was no recovery from the hemiparesis.

\section{Case IV}

A man aged 79 years with known hypertension and mild diabetes mellitus had in the past been treated for conqestive heart failure; this treatment had been stopped. Because of high blood pressure (210/ $130 \mathrm{mmHg}$ ) the patient was treated with furosemide $40 \mathrm{mg}$ once daily. After 7 days of treatment he became drowsy and was fainting. The blood pressure was $140 / 90 \mathrm{mmHg}$. Haemoglobin was $11.6 \mathrm{mmol} / 1$, blood urea $16.2 \mathrm{mmol} / 1$, blood glucose $11.1 \mathrm{mmol} / 1$. After cessation of furosemide the patient recovered completely.

\section{Case V}

A woman aged 74 years with known moderate renal insufficiency (serum creatinine $146 \mu \mathrm{mol} / 1)$, was treated with Dytenzide ${ }^{R}$ because of hypertension. The blood pressure was $240 / 130 \mathrm{mmHg}$ and metoprolol $100 \mathrm{mg}$ once daily was added to the therapy. Within 24 hours she became aphasic. The blood pressure was $150 / 90 \mathrm{mmHg}$. After cessation of metoprolol she recovered completely.

Case VI

A man aqed 71 years had been treated for hypertension with metoprolol $100 \mathrm{mg}$ thrice daily during 1 year. Because of a blood pressure of $200 / 120 \mathrm{mmHg}$, mefruside $25 \mathrm{mg}$ once daily was started. After 12 days of treatment the patient awoke with right-sided hemiparesis. At admission the blood pressure was $110 / 80 \mathrm{mmHg}$. An infarction of the left frontolateral area was diagnosed. After cessation of mefruside the patient partly recovered.

Case VII

A man aged 73 years with known partial right-sided hemiparesis and 
aphasia was treated with atenolol, $100 \mathrm{mg}$ once daily, because of hypertension $(220 / 120 \mathrm{mmHq})$. After 2 days the patient became confused and collapsed. The blood pressure was $130 / 70 \mathrm{mmHg}$ and the heart rate 50 beats/min. There was no exacerbation of the partial hemiparesis. After cessation of atenolol the blood pressure rose and the new signs of cerebral ischaemia disappeared.

\section{Case VIII}

A man aged 85 vears with known slight paresis of the right arm, atherosclerosis, non-insulin-dependent diabetes mellitus and myocardial infarction was treated with furosemide $40 \mathrm{mg} i . \mathrm{m}$. because of heart failure with severe dyspnoea. The blood pressure at that time was $240 / 140 \mathrm{mmHg}$. Because he remained dyspnoeic, $60 \mathrm{mq}$ furosemide, $240 \mathrm{mg}$ aminophylline and $10 \mathrm{mg}$ nicomorphine hydrochloride were given intravenously after $1 \mathrm{~h}$. The patient improved and a blood pressure of $190 / 105 \mathrm{mmHq}$ was measured. Treatment with furosemide, $40 \mathrm{mg}$ orally per day, was continued. After 2 days, complete pares is of the right arm developed. The blood pressure was $120 / 65 \mathrm{mmHg}$. It was thought necessary to continue furosemide medication. There was no recovery from the paresis.

\section{Case IX}

A man aged 75 years suffered from dizziness and extrapyramidal symptoms. He was admitted to hospital and normal pressure hydrocephalus was diagnosed. Because of hypertension $(190 / 120 \mathrm{mmHg})$ treatment was started with methyldopa, $250 \mathrm{mg}$ twice daily, and Dyta-urese ${ }^{R}$ once daily, resulting in a fall in blood pressure to $135 / 85 \mathrm{mmHg}$. The patient was discharged, but within 7 days he became drowsy and developed disturbances of gait. He was readmitted with right-sided hemiparesis. The blood pressure at the time was $80 / 60 \mathrm{mmHa}$. Cerebral CAT-scanning showed an infarction in the area of the left middle cerebral artery. A blood urea of $42 \mathrm{mmol} / 1$ was measured. After cessation of methyldopa and Dyta-urese ${ }^{R}$, the blood pressure rose to $135 /$ $95 \mathrm{mmH}$ and the blood urea was nearly normalized at $10 \mathrm{mmol} / \mathrm{l}$. The neurological changes proved to be irreversible. 
CHAPTER 5

\section{CONTRIBUTION OF INAPPROPRIATE TREATMENT \\ FOR HYPERTENSION TO PATHOGENESIS OF \\ STROKE IN THE ELOERLY}

P.A.F. Jansen, F.W.J. Gribnau, B.P.M. Schulte, E.F.J. Poels

Accepted for publication

British Medical Journal 


\section{ABSTRACT}

One hundred and seventy eight patients admitted to hospital with acute cerebral infarction or transient ischaemic attack were studied as to determine if their treatment had been changed during the previous three weeks and to compare their blood pressure after the stroke with premorbid values. Blood pressure measurements taken within one year before the stroke were available for 100 patients; seven of these had had a recent change in antihypertensive or diuretic treatment. Of these, three patients who had started taking furosemide because of hypertension and one whose dosage of a reserpine combination drug had been increased experienced an appreciable decrease in blood pressure immediately after the stroke; they also showed sians of haemoconcentration. The change in treatment probably contributed to the stroke in these four patients. The other three showed a smaller decrease or even an increase of blood pressure and no signs of haemoconcentration; the relation between the change in treatment and stroke is less likely in these patients.

The use of high ceiling diuretics such as furosemide in the treatment of hypertension may induce hypovolaemia and hypotension, resulting in cerebral ischaemia, and are therefore best avoided in such treatment. 


\section{INTRODUCTION}

Increased blood pressure, especially systolic hypertension, is associated with an increased risk of stroke in persons over the age of 601-5. Other studies, including one by the European Working Party on High Blood Pressure in the Elderly, have shown that treatment for hypertension in the elderly reduces cardiovascular and cerebrovascular mortality and morbidity6-9, particularly non-fatal cerebrovascular events 6 . Treatment for hypertension may prevent the recurrence of stroke10-11, especially cerebral haemorrhage12, but this effect in the elderly is less certain13-14. Nevertheless, treatment for hypertension in the elderly should be considered, though there is no consensus about the diastolic or systolic pressure above which treatment should be given.

Stroke as paradoxical side effect of treatment for hypertension has been reported $15-22$. We previously sent a questionnaire to all medical directors of Dutch nursing homes $(n=322)$, asking for information on patients who suffered a stroke shortly after the start of antihypertensive or diuretic treatment. Thirty patients were reported 23 ; of these, complete blood pressure measurements were available for nine of them. They had all had an appreciable decrease in blood pressure immediately after the stroke. To establish whether inappropriate antihypertensive or excessively drastic diuretic treatment causes such events, and if so how often, we studied patients admitted to hospital with transient ischaemic attack or acute cerebral infarction to determine if there had been any change in treatment during the three weeks preceding admission and to measure blood pressure immediately after the event and compare it with premorbid values.

\section{PATIENTS AND METHODS}

We studied 178 consecutive patients with cerebral infarction or transient ischaemic attack admitted to the neurology department of a community hospital. In the emergency department a medical history was taken, including drugs being taken, and a standard physical and neurological examination was performed. Blood pressure was measured with a shpygmomanometer, and an electrocardiogram was recorded. Blood 
was collected for measuring among others, potassium concentration, and haematocrit. In the neurology department, blood pressure was measured again, also with a sphygmomanometer and a computerised tomography scan was performed to distinguish between infarction and haemorrhage. When infarction or transient ischaemic attack was diagnosed by a neurologist according to the World Health Organisation criteria24, information on the patient's medical history was collected. The patient's general practitioner was asked by telephone for premorbid blood pressure values; he was also asked about any change in the patient's treatment during the three weeks before the event, and about the medical history, especially hypertension, diabetes mellitus and vascular disease. If no blood pressure data were available for the past year the patient was excluded from the study. Eventually a series of 100 patients remained in whom the percentage change in mean arterial blood pressure after the stroke ( $\triangle M A P$ ) was determined from the following equation:

$$
\triangle M A P=\frac{M_{A}-M A P_{B}}{M A P_{B}} \times 100 \%
$$

where $M A_{A}=$ mean arterial pressure after the stroke (mean of the two measurements taken in the emergency and neurology departments) and $M A P_{B}=$ last arterial pressure measured by the general practitioner before the stroke. In both cases mean arterial pressure was defined as the diastolic pressure plus one third of the difference between the systolic and diastolic pressures.

\section{RESULTS}

In 100 patients blood pressure had been measured within one year before admission. (mean five months; range two days to one year). Table I shows the clinical and laboratory data on these patients. Of the 47 patients known to by their doctors to suffer from hypertension according to the criteria of the WHO25, 38 (81\%) were receiving treatment. Two of the 23 patients with diabetes mellitus were dependent on insulin. Of all the 100 patients, 21 had a haematocrit value greater than 0.46 ( $r$ ange $0.46-0.56$ ). 
TABLE I

CLINICAL AND LABORATORY DATA (mean \pm SD) ON THE 100 PATIENTS

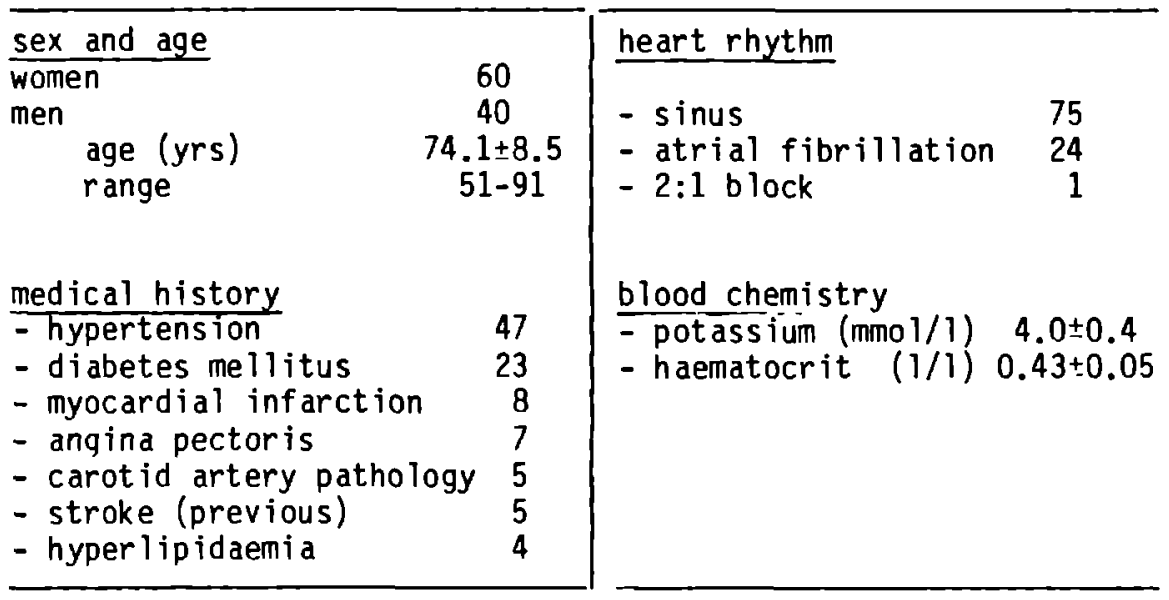

TABLE II

DIAGNOSIS AND LOCALISATION OF STROKE IN 100 ADMITTED PATIENTS

\begin{tabular}{|c|c|c|c|}
\hline Area & Cerebral & inf $\operatorname{arction}(n=88)$ & $\operatorname{TIA}(n=12)$ \\
\hline $\begin{array}{l}\text { left middle cerebral artery } \\
\text { right middle cerebral artery } \\
\text { left }+ \text { right middle cerebral } \\
\text { basilar artery } \\
\text { posterior artery } \\
\text { anterior artery }\end{array}$ & 1 artery & $\begin{array}{r}38 \\
37 \\
2 \\
6 \\
3 \\
2\end{array}$ & $\begin{array}{l}5 \\
6 \\
1\end{array}$ \\
\hline
\end{tabular}

TABLE III

CHANGE IN MEDICATION ( $N=16)$ IN THE THREE WEEKS PRECFDING STROKE IN THE 100 PATIENTS STUDIED

\begin{tabular}{lccc}
\hline DRUG & started & dose increased & stopped \\
\hline furosemide & 5 & 1 & 1 \\
acetosal/dipyridamol & 3 & & 1 \\
acenocoumarol & 1 & & $1 \star$ \\
triamterene & $1 \star$ & & \\
$\begin{array}{l}\text { isosorbide dinitrate } \\
\text { haloperidol }\end{array}$ & 1 & & \\
penicillin & 1 & 1 & \\
reserpine-dihydralazine- & & & \\
hydrochlorthiazide & & &
\end{tabular}

* in these patients furosemide was started also 
Table II lists the diagnoses and localisations of infarction and transient ischaemic attack. Cerebral infarction was diagnosed in 88 patients, and transient ischaemic attack in 12.

In 16 patients the treatment had been changed during the previous three weeks (Table III): 12 had started treatment with new drugs (furosemide as well as triamterene in one), two had had their dosages increased, and three had stopped taking drugs (one patient had stopped taking acenocoumarol and had started taking furosemide).

The figure shows the changes in mean arterial blood pressure after infarction and transient ischaemic attack.

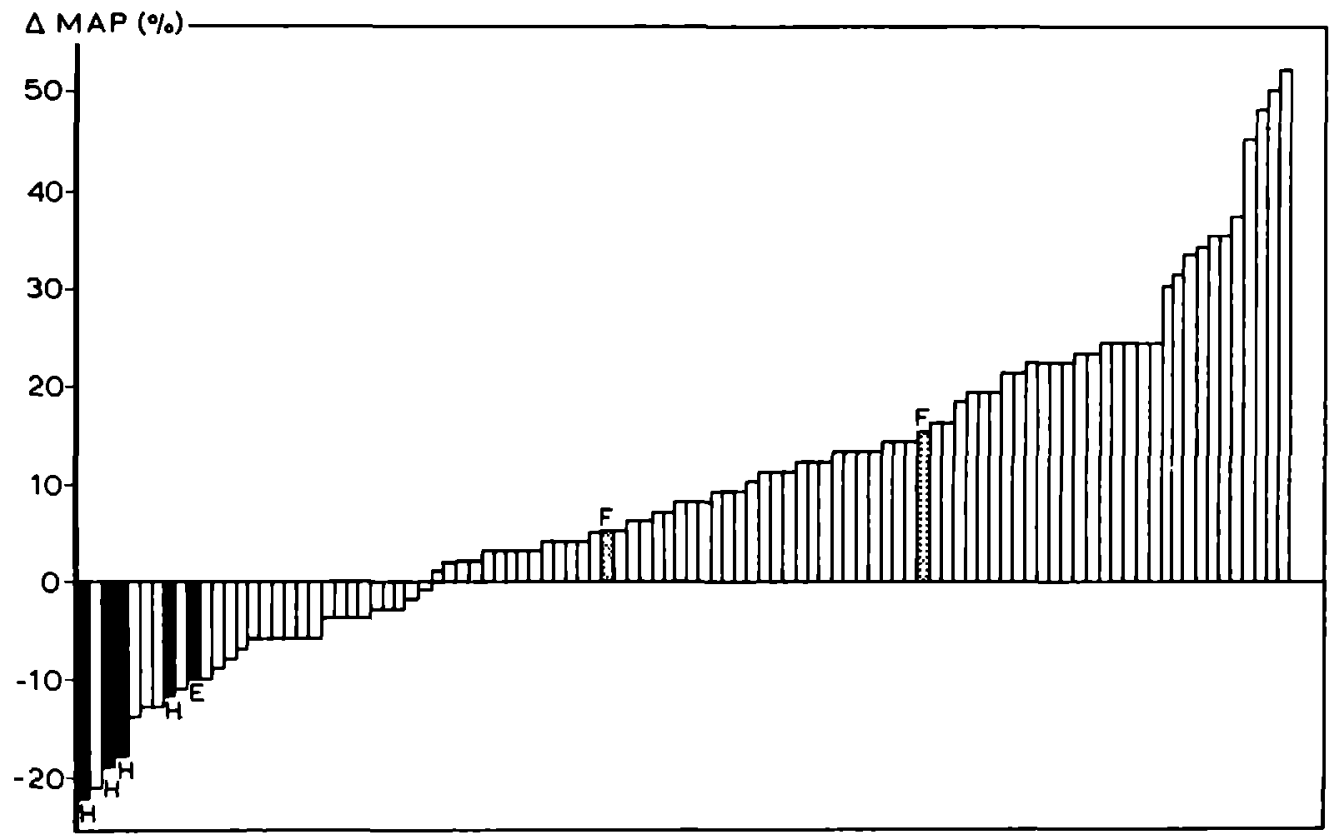

Fig. 1.

Change (percentage) in mean arterial pressure ( $\triangle M A P)$ in 100 patients admitted with stroke.

Black bars represent five patients whose treatment was chanqed because of oedema $(E)$ and hypertension $(H)$; dotted bars represent two patients whose treatment was changed because of heart failure $(F)$. 
Mean arterial pressure increased in 71 patients and decreased in 29. The marked bars in Fig. 1 indicate the patients who started or increased their dosage of antihypertensive or diuretic treatment during the previous three weeks.

Table IV shows the data on these seven patients. For illustration one case history (case 6) is presented.

\section{Case history}

A 72 year old woman had no history of pre-existing hypertension, congestive heart fallure or diabetes mellitus and was not receiving any treatment but sometimes complained of dizziness. The general practitioner had been called to her home because she was confused and had loss of vision in the right eye and loss of strength in one hand. On his arrival the neurological signs had disappeared, but because of her blood pressure of $190 / 115 \mathrm{mmHg}$ furosemide (40 $\mathrm{mg}$ daily) was started. After two days she complained of a constant dizziness and was dysphasic; on admission she had right sided hemianoosia and paralysis of the right arm and leg. Pulsations of the carotid arteries were normal without bruits, an electrocardiogram showed a sinus rhythm, and haematocrit was 0.48. A cerebral computerised tomography scan showed infarction in the left occipital area. On admission her blood pressure was $160 / 90 \mathrm{mmHg}$; the decrease in mean arterial pressure was $19 \%$.

\section{DISCUSSION}

Cerebral ischaemia occurring as a side effect of treatment for hypertension has been reported previously15-23. In our study seven of 100 patients had important changes in antihypertensive or diuretic treatment during the three weeks before their stroke. We believe that these changes caused a decrease in blood pressure and an increase in the haematocrit value that contributed to the stroke in four patients. We realize that the blood pressures used in the study are based on few measurements and that the blood pressures before the stroke, all recorded by the general practitioner, had led to the decision to start treatment for hypertension or to increase the dose. 
TABLE IV

SEVEN PATIENTS WITH START OR DOSE RISE OF ANTIHYPER IENSIVE/DIURETIC TREATMENT IN THE THREE WEEKS BEFORE STROKE $(M=$ male, $F=$ female, $C H F=$ congestive heart fallure, $B P=$ blood pressure, HR = heart rate and rhythm, $H T=$ haematocrit, $S R=$ sinus rhythm, $A F=$ atrial fibrillation, $R M A=$ right middle cerebral artery, LMA = left middle cerebral artery, $P A=$ posterıor cerebral artery)

\begin{tabular}{|c|c|c|c|c|c|c|c|c|c|c|}
\hline Patient & $\begin{array}{l}\operatorname{Age}(y г) \\
\operatorname{sex}\end{array}$ & medication & $\begin{array}{l}\text { new drug } \\
\text { or dose rise } \\
\text { (period) }\end{array}$ & indication & $\begin{array}{l}\text { BP before } \\
\text { treatment } \\
(\mathrm{mmHg})\end{array}$ & $\begin{array}{l}B P * a f t e r \\
\text { stroke } \\
(\mathrm{mmHg})\end{array}$ & $\underset{(\%)}{\triangle M A P}$ & $H R$ & $\begin{array}{l}\text { HT } \\
(1 / 1)\end{array}$ & diagnosis \\
\hline 1 & $\begin{array}{l}81 \\
M\end{array}$ & $\begin{array}{l}\text { digoxin } \\
\text { insulin }\end{array}$ & $\begin{array}{l}\text { furosemide } \\
(10 \text { days) } \\
(80 \mathrm{mg})\end{array}$ & $\mathrm{CHF}$ & $150 / 80$ & $155 / 100$ & +15 & $104 S R$ & 0.41 & $\begin{array}{l}\text { infarction } \\
\text { LMA }\end{array}$ \\
\hline 2 & $\begin{array}{l}75 \\
M\end{array}$ & $\begin{array}{l}- \\
\text { (acenocoumarol } \\
1 \text { week stopped) }\end{array}$ & $\begin{array}{l}\text { furosem } 1 \text { de } \\
\text { (1 day } 40 \mathrm{mg})\end{array}$ & $\mathrm{CHF}$ & $210 / 110$ & $220 / 115$ & +5 & $112 S R$ & 0.38 & $\begin{array}{l}\text { infarction } \\
\text { RMA }\end{array}$ \\
\hline 3 & $\begin{array}{l}69 \\
M\end{array}$ & $\begin{array}{l}\text { sulphonyl urea } \\
\text { salbutamol } \\
\text { furosemide } \\
\text { ( } 40 \mathrm{mg} \text { twice } \\
\text { weekly) }\end{array}$ & $\begin{array}{l}\text { furosemide } \\
\text { (10 days } \\
40 \text { mg once } \\
\text { dally) }\end{array}$ & oedema & $120 / 90$ & $130 / 70$ & -10 & $150 \mathrm{AF}$ & 0.33 & $\begin{array}{l}\text { Infarction } \\
\text { LMA }\end{array}$ \\
\hline 4 & $\begin{array}{l}79 \\
F\end{array}$ & $\begin{array}{l}\text { reserpine-dihydral } \\
\text { hydrochlorthiazide } \\
(1 \times 1)\end{array}$ & (6 days $2 \times 1$ ) & hypertension & $220 / 130$ & $193 / 115$ & -12 & BB SR & 0.48 & $\begin{array}{l}\text { infarction } \\
\text { LMA }\end{array}$ \\
\hline 5 & $\begin{array}{l}67 \\
F\end{array}$ & $\begin{array}{l}\text { metoprolal } \\
\text { digoxin }\end{array}$ & $\begin{array}{l}\text { furosemide } \\
\text { ( } 17 \text { days } \\
40 \mathrm{mg} \text { on } \\
\text { alternate days) }\end{array}$ & hypertension & $170 / 115$ & $150 / 90$ & -18 & $76 \mathrm{AF}$ & 0.51 & $\begin{array}{l}\text { infarction } \\
\text { RMA }\end{array}$ \\
\hline 6 & $\begin{array}{l}72 \\
F\end{array}$ & - & $\begin{array}{l}\text { furosem } 1 \mathrm{de} \\
(2 \text { days } 40 \mathrm{mg})\end{array}$ & hypertension & $190 / 115$ & $160 / 90$ & -19 & $68 S R$ & 0.48 & $\begin{array}{l}\text { infarction } \\
\text { PA }\end{array}$ \\
\hline 7 & $\begin{array}{l}72 \\
M\end{array}$ & $\begin{array}{l}\text { methyldopa } \\
\text { glybenc] amide }\end{array}$ & $\begin{array}{l}\text { furosemide } \\
40 \text { mg and } \\
\text { tr } 1 \text { amterene } \\
(7 \text { days } 1 \times 1 \text { ) }\end{array}$ & hypertension & $160 / 110$ & $140 / 78$ & -22 & 92 SR & 0.52 & $\begin{array}{l}\text { infarction } \\
\text { LMA }\end{array}$ \\
\hline
\end{tabular}

\footnotetext{
* mean of two values
} 
Side effects of such treatment are better studied prospectively, but we consider it unethical to start incorrect treatment to determine severe side effects. We therefore felt obliged to confine ourselves to this retrospective study despite its shortcomings.

The relationship between change in treatment and stroke is difficult to prove in this study because risk factors for stroke were present in all the patients: five had hypertension, two had atrial fibrillation, one had had a transient ischaemic attack two days before complete stroke, two had diabetes mellitus and one (case 2) had stopped taking acenocoumarol one week before the event. Nevertheless, we believe that in cases $4,5,6$ and 7 the change in treatment has at least contributed to the pathogenes is of the stroke. In cases 1,2 and 3 the relation between treatment and stroke is less likely because of the lack of signs of haemoconcentration, the increase in blood pressure (cases 1 and 2), the cessation of treatment with acenocoumarol in case 2 and the uncontrolled atrial fibrillation in case 3 .

In our opinion the elderly are especially at risk of cerebral ischaemia from reduced blood pressure for several reasons. Firstly, the baroflex is less sensitive in old people and a quick decrease in blood pressure cannot be compensated immediately as in the young 26 . Secondly, cerebral autoregulation may be impaired in the elderly27. The brain is protected from fluctuations in blood pressure by autoregulation. When blood pressure decreases the cerebral vessels dilate; when blood pressure increases they constrict, resulting in a constant cerebral blood flow at mean arterial pressures ranging from 60 to $150 \mathrm{mmHg}$ in normal subjects. The brain of patients with chronic hypertension is more vulnerable to hypotension because the cerebral autoregulatory curve shifts to the right; in these patients a reduction of cerebral blood flow occurs at a higher arterial oressure than in normotensive subjects28. A reduction in mean arterial pressure of about $25 \%$ is required to reach the lower limit of cerebral blood flow autoregulation; a further reduction to about $55 \%$ is needed to cause symptoms of brain hypoperfusion in both hypertensive and normotensive subjects aged under 66 years 29 . 
In 1956 an inverse correlation was shown between cerebral blood flow and age, with a pressure reduction of about $25 \%$ in the elderly compared with the young 30 . This finding was later confirmed by other authors using more modern methods 31,32 .

Thirdly, cerebral blood flow has a lower pressure with a high haematocrit value (over 0.46$)^{33}$, though regulatory mechanisms can maintain normal cerebral oxygen transport despite increased viscosity of plasma and whole blood 34 .

Atherosclerosis might be considered important in decreasing the flexibility of arteries in the brain, patients with the most pronounced arteriosclerosis being most at risk of stroke in the event of a hypotensive episode. Several studies, however, do not support this concept 35,36. Torvik and Skullerud studied 115 cases of cardiac arrest and found no correlation between the degree of arteriosclerosis and the risk of brain infarcts as a complication of the hypotensive episode 36 . There is a relation between the morphological substrate and the outcome of a period of hypotension as shown by the neuropathological observations of 11 patients by Adams et al.37; the necrosis of grey and white matter at the boundary zones ("watersheds") seemed to be attributable to a precipitate reduction in systemic blood pressure, while diffuse alterations seemed to be the result of a moderate but sustained systemic hyootension.

For these reasons and because the elderly are more likely to suffer side effects38-39, blood pressure should be reduced gradually and treatment started with a small dose of relatively safe antihypertensive agent. Primarv, treatment for hypertension in the elderly is generally with a thiazide diuretic ${ }^{39}$.

Inappropriate antihypertensive treatment may cause stroke: powerful high ceiling diuretics such as furosemide may induce hypovolaemia and hypotension, resulting in cerebral ischaemia.In the treatment of hypertension these drugs are best avoided. 


\section{REFERENCES}

1. Kannel WB, Wolf PA, Verter J, MCNamara PM. Epidemioloqic assessment of the role of blood pressure in stroke: The Framingham Study. JAMA 1970; 214 : 301-10.

2. Kannel WB, Wolf PA, McGee DL, Dawber TR, McNamara P, Castelli WP. Systolic blood pressure, arterial rigidity, and risk of stroke. The Framingham Study. JAMA 1981; 245 : 1225-9.

3. Shekelle RB, Ostfeld AM, Klawans HL. Hypertension and risk of stroke in an elderly population. Stroke 1974; $5: 71-5$.

4. Forette $F$, de la Fuente $X$, Golmard $J-L$, Henry $J-F$, and Hervy $M-P$. The prognostic significance of isolated systolic hypertension in the elderly. Results of a ten year longitudinal survey. $\mathrm{Cl}$ in Exp Hyp 1982; (A4)7 : 1177-91.

5. Colandrea MA, Friedman GD, Nichaman MZ, Lynd CN. Systolic hypertension in the elderly. An epidemiological assessment. Circulation 1970; 41 : 239-45.

6. Amery $A$, Birkenhäger $W, B r i x k o P$, et al. Mortality and morbidity results from the European Working Party on high blood pressure in the elderly trial. Lancet 1985; I : 1349-54.

7. Veterans Administration Cooperative Study Group on Antihypertensive Agents. Effects of treatment on morbidity in hypertension. III. Influence of age, diastolic pressure and prior cardiovascular disease; further analysis of side effects. Circulation 1972; 45 : 991-1004.

8. Hypertension Detection and Follow-up Program Cooperative Group. Five year findings of the hypertension detection and follow-up program. II. Mortality by race, sex and age. JAMA 1979; 242 : 277.

9. Report by the Management Committee. The Australian therapeutic trial in mild hypertension. Lancet 1980; I : 1261-7.

10. Marshall J. A trial of long-term hypotensive therapy in cerebrovascular disease. Lancet 1964; I : 10-2.

11. Beevers DG, Fairman MJ, Hamilton M, Harpur JE. Antihypertensive treatment and the course of established cerebral vascular disease. Lancet 1973; I : 1407-9. 
12. Black DG, Heagerty AM, Bing RF, Thurston H, Swales JD. Effects of treatment for hypertension on cerebral haemorrhage and infarction. Br Med J 1984; 289 : 156-9.

13. Hypertension-Stroke Cooperative Study Group. Effect of antihypertensive treatment on stroke recurrence. JAMA 1974; 229 : 409-18.

14. Carter $A B$. Hypotensive therapy in stroke survivors. Lancet 1970; I : 485-9.

15. Graham DI. Ischaemic brain damage of cerebral perfusion failure type after treatment of severe hypertension. Br Med J 1975; IV : 739.

16. Jackson G, Mahon W, Pierscianowski TA, Condon J. Inappropriate antihypertensive therapy in the elderly. Lancet 1976; II : 13178.

17. Cove $\mathrm{DH}$, Seddon $M$, Fletcher RF, Dukes DC. Blindness after treatment for malignant hypertension. Br Med J 1979; II : 245-6.

18. Ledingham JGG, Rajagopalan B. Cerebral complications in the treatment of accelerated hypertension. Q J Med 1979; $48: 25-41$.

19. Pitlik S, Manor RS, Lipshitz I, Perry G, Rosenfeld J. Transient retinal ischaemia induced by nifedipine. $\mathrm{Br}$ Med J 1983; 287 : 1845-6.

20. Phillips MS, Jones JV. Emergency treatment of high blood pressure with oral atenolo1. (Letter) Br Med J 1981; $283: 58$.

21. Strandgaard $S$, Andersen GS, Ahlgreen P, Nielsen PE. Visual disturbances and occipital brain infarct following acute, transient hypotension in hypertensive patients. Acta Med Scand 1984; 216 : 417-22.

22. Ross Russel RW, Page NGR. Critical perfusion of brain and retina. Brain 1983; $106: 419-34$.

23. Jansen PAF, Schulte BPM, Meyboom RHB, Gribnau FWJ. Antihypertensive treatment as a possible cause of stroke in the elderly. Age Ageing 1986; 15 : 129-38.

24. WHO. Cerebrovascular diseases - prevention, treatment and rehabilitation. Techn Rep Ser 1971; 469.

25. WHO. Report of a WHO Expert Comittee. Arterial hypertension. WHO Techn Rep Ser 1978; 628. 
26. Gribbin B, Pickering TG, Sleight P, Peto R. Effect of age and high blood pressure on baroreflex sensitivity in man. Circ Res 1971; $29: 424-31$.

27. Wollner L, MCCarthy ST, Soper NDW, Macy DJ. Failure of cerebral autoregulation as a cause of brain dysfunction in the elderly. Br Med J 1979; I : 1117-8.

28. Strandgaard S, Olesen J, Skinhoj E, Lassen NA. Autoregulation of brain circulation in severe arterial hypertension. Br Med $\mathrm{J} 1973$; I : 507-10.

29. Strandgaard S. Autoregulation of cerebral blood flow in hypertensive patients. The modifying influence of prolonged antihypertensive treatment on the tolerance to acute, drug-induced hypotension. Circulation 1976; $53: 720-7$.

30. Kety SS. Human cerebral blood flow and oxygen consumption as related to aging. J Chron Dis $1956 ; 3: 478-86$.

31. Thomas DJ, Zilkha E, Redmond $S$ et al. An intravenous ${ }^{133}$ xenonclearance technique for measuring cerebral blood flow. J Neurol Sci 1979; 40 : 53-63.

32. Davis SM, Ackerman RH, Correia JA et al. Cerebral blood flow and cerebrovascular $\mathrm{CO}_{2}$ reactivity in stroke-aqe normal controls. Neurology 1983; 33 : 391-9.

33. Thomas DJ, Marshall J, Ross Russell RW et al. Effect of haematocrit on cerebral blood-flow in man. Lancet 1977; II : 941-3.

34. Brown MM, Marshall J. Regulation of cerebral blood flow in response to changes in blood viscosity. Lancet 1985; I : 604-9.

35. Kende11 RE, Marshall J. Role of hypotension in the genesis of transient focal cerebral ischaemic attacks. Br Med J 1963; II : $344-8$.

36. Torvik A, Skullerud K. How often are brain infarcts caused by hypotensive episodes? Stroke 1976, $7,255-7$.

37. Adams $J H$, Brierley B, Connor RCR, Treip CS. The effects of systemic hypotension upon the human brain, clinical and neuropathological observations in 11 cases. Brain 1966; 89 : 235-80. 
38. Hurwitz $H$. Predisposing factors in adverse reactions to drugs. Br Med J 1969; I : 536-9.

39. Williams $B 0$. Use and misuse of diuretics in the elderly. Prescr $J$ 1985; $25: 51-6$. 


\section{CEREBRAL INFARCTION AS CONSEQUENCE OF INAPPROPRIATE ANTIHYPERTENSIVE TREATMENT}

PAF Jansen, BPM Schulte, EFJ Poels, RHB Meyboom, FWJ Gribnau 


\section{SUMMARY}

Cerebral ischaemia as possible side effect of medication was studied in 54 patients treated with antihypertensive drugs and admitted to hospital because of a cerebral infarction. Three patients (ages 67, 72 and 72) had started furosemide within the three weeks before stroke because of hypertension; all three patients had a marked fall in blood pressure after stroke as compared with pretreatment levels. The case histories of the 3 patients are presented. It is concluded that the powerful heigh-ceiling diuretic furosemide may cause hypovolaemia and hypotension and may so contribute to the occurrence of stroke, especially in elderly patients not suffering from congestive heart failure. 
INTRODUCTION

Hypertension is the most important risk factor for cerebrovascular diseases 1,2 . Effective antihypertensive treatment reduces morbidity and mortality of these disorders ${ }^{3}$, in elderly hypertensive patients $4-7$ as we11. It is therefore to be expected that more and more aged patients will be treated with antihypertensive drugs.

In drug treatment, adverse reactions are not uncommon. Of the several antihypertensive agents now in use, many unwanted effects are known; some are dose-independent but most are dose-dependent. Detection of an adverse drug reaction is extremely difficult when the clinical manifestation is identical with the disease that the drug tried to prevent. We studied cerebral ischaemia as possible side effect of antihypertensive treatment. The aim was to establish whether oral antihypertensive or diuretic treatment, inducing a steep fall in blood pressure, may cause cerebral infarction.

MATERIAL AND METHODS

Over a period of one year all patients admitted to a general hospital with cerebral infarction and using antihypertensive or diuretic agents, were studied. The general practitioners of the patients were asked by telephone for the indication to prescribe such drug treatment; blood pressure values were also asked for. Only the blood pressures measured a few days to one year before the cerebral infarction were consideren of value. A series of 54 patients was thus formed. In the emergency department blood pressure was measured and blood was sampled for measurement of sodium, potassium, creatinine, blood urea nitrogen, haemoglobin, haematocrit and albumin. In the neurological department blood pressure was measured at least every six hours by trained nurses. The values are expressed as mean arterial pressure (MAP): MAP = diastolic $+1 / 3$ pulse pressure $(m m H a)$.

The change in blood pressure after the event is expressed as $\triangle M A P$ :

$$
\triangle M A P=\text { MAP after the event }- \text { MAP before the event } \times 100 \%
$$

MAP before the event 
As "MAP after the event" the mean of the first two blood pressure measurements was taken (the one in the emerqency department and the first one in the neurological department respectively). On the first day after admission a cerebral CT-scan was performed. Cerebral infarction was diagnosed by a neurologist according to the criteria of the $W H 0^{8}$.

\section{RESULTS}

Clinical details on the 54 patients studied are listed in Table I. The antihypertensive and diuretic drugs used by the patients, are listed in Table II. None of the 16 patients with diabetes mellitus, showed a severe dysregulation of the blood sugar and none of the 54 patients had diarrhoea as a cause of hypovolaemia. Five patients had started an antihypertensive or diuretic drug within 3 weeks before the event. In all five cases the drug involved was furosemide, in two cases given because of congestive heart failure and in the other three because of hypertension. The $\triangle M A P$ of the patients is presented in Fig. 1. Thirty-seven patients (69\%) had an increase in MAP after cerebral infarction and seventeen (31\%) a fall. The two patients given furosemide because of congestive heart failure had an increase of 5 and $15 \%$ respectively. The three patients given furosemide because of hypertension, however, had a decrease in MAP by 18,19 and $22 \%$ after cerebral infarction. These three patients had the most marked fall in blood pressure of all patients (they are marked with the black bars in Fig. 1). The case histories of these patients are presented.

\section{CASE HISTORIES}

Patient $A$, a woman aged 67 years, had had hypertension, atrial fibrillation and non-dependent diabetes mellitus for some years. She used metoprolol once daily and digoxin $0.125 \mathrm{mg}$ daily as medication. Check of the blood pressure revealed that it was still increased $(170 / 115 \mathrm{mmHg})$ and she had been prescribed furosemide $40 \mathrm{mg}$ on alternate days. After seventeen days treatment the patient had noted loss of strength in the left arm and leg and there had been falls. At ad- 
TABLE I. Clinical details on the 54 patients in this study (in part mean \pm S.D.)

\begin{tabular}{llll} 
Sex and age & \multicolumn{3}{l}{ Laboratory } \\
women & 39 & sodium (mmol/1) & $140 \pm 4$ \\
men & 15 & potassium $(\mathrm{mmol} / 1)$ & $3.9 \pm 0.4$ \\
age (years) & $73 \pm 9$ & creatinine $(\mu \mathrm{mol} / 1)$ & $104 \pm 39$ \\
& & blood urea $(\mathrm{mmol} / 1)$ & $7.6 \pm 2.7$ \\
& haemoglobin $(\mathrm{mmol} /)$ & $9.3 \pm 1.1$ \\
& haematocr it $(1 / 1)$ & $0.44 \pm 0.05$ \\
& & albumin $(g / 1)$ & $38 \pm 4$ \\
\hline
\end{tabular}

TABLE II. Antihypertensive and diuretic drugs used by the 54 patients ( $n$ = number of patients)

\begin{tabular}{lclc} 
Agents & $\frac{\mathrm{n}}{\text { indication }}$ & $\underline{\mathrm{n}}$ \\
thiazide diuretic & 25 & $\begin{array}{l}\text { hypertension } \\
\text { congestive heart failure }\end{array}$ & 18 \\
furosemide & 19 & & 36 \\
B-blocking drug & 18 & number of agents used & \\
methyldopa & 7 & simultaneously & \\
trianterene & 5 & & 31 \\
Captopri1 & 2 & 1 agent & 20 \\
labetalol & 2 & 2 agents & 2 \\
prazosine & 1 & 3 agents & 1 \\
Adelphan-EsidrexR & 1 & 4 aqents & \\
\hline
\end{tabular}


mission a left-sided hypotonic hemiparesis was present. Blood pressure was $150 / 90 \mathrm{mmHg}(\triangle M A P-18 \%)$. The heart rate was 76 beats per minute, and irregular. There were normal carotid artery pulsations without bruits. The ECG showed atrial fibrillation with a ventricular rate of 76 beats per minute. A cerebral CT-sCan showed a right-sided infarction in the parietotemporal area. Blood chemistry: sodium $140 \mathrm{mmol} / 1$, potassium $3.0 \mathrm{mmol} / 1$, blood sugar $14.7 \mathrm{mmol} / 1$, creatinine $71 \mu \mathrm{mol} / 1$, blood urea $5.0 \mathrm{mmol} / 1$, haemoglobin $10.8 \mathrm{mmol} / 1$, haematocrit $0.51 \mathrm{l} / 1$ and albumin $42 \mathrm{~g} / 1$. The patient had been given an isotonic salt infusion, with an increase in blood pressure to $170 / 110 \mathrm{mmHg}$ as a result. Because of development of congestive heart failure after a few days, it was decided to continue the furosemide. The hemipares is recovered partly.

Patient B, a woman aged 72 years, had always been in good health. She sometimes suffered from dizziness. The general practitioner was called to her home because of confusion and loss of strength in the right hand; at the time of his visit, all neurological disturbances had disappeared. The patient's blood pressure was $190 / 115 \mathrm{mmHg}$ and therefore furosemide $40 \mathrm{mg}$ once daily was prescribed. After two days the patient complainted of constant dizziness, she was dysphasic and there was again loss of strength in the right hand. At admission dysarthria, right-sided hemianopsia and right-sided paralysis of the arm and leg were present. Blood pressure was 160/90 (AMAP -19\%). There were normal carotid artery pulsations. The ECG showed sinus rhythm. The cerebral CT-scan revealed an infarction in the left occipital area. Blood chemistry: sodium $141 \mathrm{mmol} / 1$, potassium $3.7 \mathrm{mmol} / 1$, creatinine $80 \mu \mathrm{mor} / 1$, blood urea $5.7 \mathrm{mmol} / 1$, haemoglobin $10.0 \mathrm{mmol} / 1$, haematocrit $0.48 \mathrm{1} / 1$ and albumin $45 \mathrm{~g} / 1$. The furosemide treatment was not stopped. Blood pressure ranged between $140 / 80$ and $170 / 90 \mathrm{mmH}$ in the next few days. The hemiparesis disappeared.

Patient $C$, a man aged 72 years, had had hypertension and diabetes mellitus for some years. He used methyldopa twice daily, glibenclamide thrice daily and a diet free of salt and sugar. The blood 


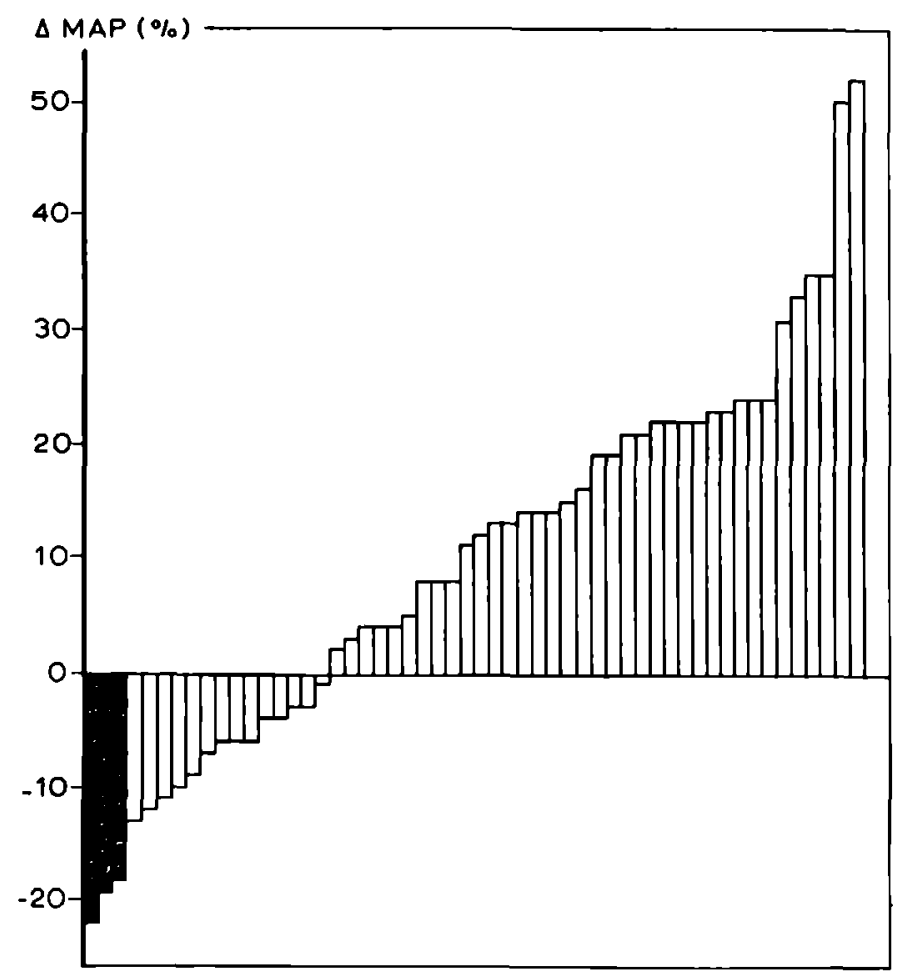

Fig. 1.

Change of blood pressure in the 54 patients on the first day after cerebral infarction as compared with the level measured a few days to one year before the event, expressed as SMAP $(\%)$. The marked bars represent the 3 patients described. 
blood pressure was found to be $160 / 110 \mathrm{mmHg}$. Furosemide $40 \mathrm{mg}$ once daily and triamterene once daily were added to the therapy. After seven days be became drowsy, complainted of dizziness, had disturbance of speech and loss of strength in the right arm and leg. At admission a right-sided hemiparesis was present. The patient was

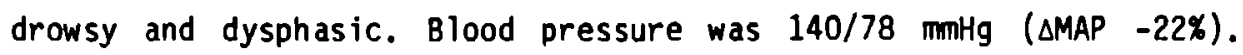
There were normal carotid artery pulsations, without bruits. The ECG showed sinus rhythm. The cerebral CT-sCan showed no abnormalities. EEG showed abnormal function of the brain in the left fronto-temporal area. Blood chemistry: sodium $142 \mathrm{mmol} / 1$, potassium $3.5 \mathrm{mmol} / 1$, creatinine $100 \mu \mathrm{mol} / 1$, blood urea $7.2 \mathrm{mmol} / 1$, blood sugar $15.5 \mathrm{mmol} /$ 1 , haemoglobin $11.1 \mathrm{mmol} / 1$, haematrocrit $0.521 / 1$ and albumin $43 \mathrm{~g} / 1$. At admission methyldopa and triamterene were stopped and the patient was given extra fluid via a catheter. Blood pressure increased to $170 / 90 \mathrm{mmHg}$. Furosemide was not stopped. The hemiparesis partly disappeared.

\section{DISCUSSION}

In our opinion antihypertensive treatment with furosemide at least contributed to the occurrence of stroke in these 3 patients. They all had a marked fall in blood pressure after cerebral infarction in comparison with pre-treatment levels. A fall in blood pressure after stroke is remarkable because in most patients it is increased on the first day after the event; a Dutch epidemiological study revealed an increase in blood pressure in $90 \%$ of the patients with stroke ${ }^{9}$.

In our view it is therefore not a coincidence that the 3 patients described are on the left side of Fig. 1. The powerful high-ceiling diuretic furosemide may cause a steep fall in blood pressure; in the 3 patients a high haematocrit value and relatively high plasma albumin concentration were present reflecting hypovolaemia. The clinical evidence in such cases is not complete; in the patients other risk factors for stroke were present, like the hypertension itself, diabetes mellitus and (in one) atrial fibrillation. In the two patients with diabetes mellitus the blood sugar was not grossly dysregulated; in the patient with atrial fibrillation, the ventricular 
rate was not high. One patient suffered a TIA two days before the event; in this case failure of cerebral autoregulation was possibly present, as described in patients with stroke10; the cerebral blood flow is directly dependent on blood pressure in such a situation, resulting in cerebral ischaemia even after only a rather small fall in blood pressure. Because it was not clear at admission why furosemide was prescribed in the 3 patients, it was not stopped in the first days after stroke. Blood pressure values as measured before stroke, are usually not known at the time of the event; even a marked fall in blood pressure after the event may therefore easily remain unnoticed and stroke as side effect of antihypertensive treatment not considered. In literature thirty such patients have been reportedll. The pathology of cerebral ischaemia induced by hypotension, was studied by Adams et al.12. After a quick fall in blood pressure, they found lesions in the "watershed areas", the border zones of the main cerebral arteries; more diffuse alterations were seen after a moderate but prolonged lowering of the pressure.

For several reasons the elderly are especially at risk for developing cerebral ischaemia after a quick or steep fall in blood pressure. Firstly, the baroreceptor is less sensitive in the aged, and lowering of blood pressure cannot be compensated as adequately as in the young 13. Another point of importance is the shift to the right of the autoregulatory curve of the brain in patients with longstanding hypertension 14,15 . This autoregulation guarantees a constant cerebral blood flow in MAP ranges from 60 to $150 \mathrm{mmHg}$; when blood pressure increases, vessels constrict and prohibit increase of blood flow and vice versa. In patients with hypertension, there is failure of cerebral autoregulation, with reduction of cerebral blood flow at higher MAP levels than in normotensives.

In the elderly (over 65 years of age), cerebral autoregulation can be impaired even in the absence of hypertension 16 .

Moreover, cerebral blood flow decreases with increasing age 17,18 . Finally, cerebral blood flow is lower with a high haematocrit lover 0.46). The elderly patient with hypertension and a high haematocrit is therefore especially at risk for cerebral ischaemia after a quick 
or steep reduction of blood pressure. The drug of choice in the treatment of hypertension in the aged is usually a thiazide diuretic20,21. The high-ceiling diuretics, like furosemide, are quick and powerful and may cause a steep fall in blood pressure22; they are therefore inappropriate for the treatment of hypertension. In the case of congestive heart failure there is a good indication to prescribe high-ceiling diuretics; induction of diuresis causes no depletion of volume in such a situation, because fluid is replaced from the extravascular compartment23. Blood pressure should be monitored however, because hypovolaemia as a side effect of furosemide is frequently seen (4-14.5\%), especially in the elderly patient 24,25 .

In conclusion, when starting antihypertensive treatment, especially in an elderly patient, one should prescribe appropriate drugs aiming at a gradual lowering of the blood pressure. Because the high-ceiling diuretics are powerful, with a risk of hypovolaemia, hvpotension and - as is suggested also by our results - even cerebral ischaemia, they are not suitable in the treatment of hypertension. 


\section{REFERENCES}

1. Kannel WR. Role of blood pressure in cardiovascular morbidity and mortality. Prog Cardiovasc Dis 1974; $17: 5-24$.

2. Kannel WB. Wolf PA, Verter $J$ and McNamara PM. Epidemiologic assessment of the role of blood pressure in stroke: The Framingham Study. JAMA 1970; 214 : 301-10.

3. Hypertension Detection and Follow-up Program Cooperative Group. Five year findings of the hypertension detection and follow-up program. I. Reduction in mortality of persons with high blood pressure, including mild hypertension. JAMA 1979; 242 : 2562-71.

4. Amery $A$, Birkenhäger $W, B r i x k \circ P$, et al. Mortality and morbidity results from the European Working Party on high blood pressure in the elderly trial. Lancet 1985; I : 1349-54.

5. Veterans Administration Cooperative Study Group on Antihypertensive Agents. Effects of treatment on morbidity in hypertension. III. Influence of age, diastolic blood pressure and prior cardiovascular disease; further analysis of side effects. Circulation 1972; 45 : 991-1004.

6. Hypertension Detection and Follow-up Program Cooperative Group. Five year findings of the hypertension detection and follow-up program. Il. Mortality by race-sex and age. JAMA 1979; 242 : 2572-7.

7. Report by the Management Committee. The Australian therapeutic trial in mild hypertension. Lancet 1980; I : 1261-7.

8. Hatano S. Control of stroke in the community-methodological considerations and protocol of WHO stroke register. Working document for meeting on community control of stroke and hypertension. Geneva, 6-13 December 1973 (WHO document No. CVD/S/73.6 Rev. 1).

9. Schulte BPM, Leyten ACM, Herman B. Pre-stroke and immediate poststroke hypertension: neuroepidemiological data. In: Meyer JS, Lechner H, Reivich M, Ott E (eds) Cerebral Vascular Disease 5 (12th Salzburg Conference). Excerpta Medica, Amsterdam-New York0xford 1985; 286. 
10. Johnson RH, Lambie OG, Spalding JMK (eds) Neurocardiology. The interrelationship between dysfunction in the nervous and cardiovascular systems. WB Saunders, London 1984; 261-322.

11. Jansen PAF, Schulte BPM, Meyboom RHR, Gribnau FWJ. Antihypertensive treatment as a possible cause of stroke in the elderly. Age Ageing 1986; $15: 129-38$.

12. Adans JH, Brierley B, Connor RCR, Treip CS. The effects of systemic hypotension upon the human brain, clinical and neuropathological observations in 11 cases. Brain 1966; $89: 235-80$.

13. Gribbin B, Pickering TG, Sleight P, Peto R. Effect of age and high blood pressure on baroreflex sensitivity in man. Circ Res 1971; $29:$ 424-31.

14. Strandgaard S, Olesen J, Skinhoj E, Lassen NA. Auto-regulation of brain circulation in severe arterial hypertension. Br Med J 1983; I : 507-10.

15. Strandgaard $S$. Autoregulation of cerebral blood flow in hypertensive patients. The modifying influence of prolonged antihypertensive treatment on the tolerance to acute, drug-induced hypotension. Circulation 1976; $53: 720-7$.

16. Wollner L, MCCarthy ST, Soper NDW, Macy. DJ. Failure of cerebral autoregulation as a cause of brain dysfunction in the elderly. Br Med J 1979; I : 1117-8.

17. Thomas DJ, Zilkha $E$, Redmond $S$ et al. An intravenous 133 xenonclearance technique for measuring cerebral blood flow. J Neurol Sci 1979; $40: 53-63$.

18. Davis SM, Ackerman RH, Correia JA et al. Cerebral blood flow and cerebrovascular $\mathrm{CO}_{2}$ reactivity in stroke-age normal controls. Neurology 1983; 33 : 3919.

19. Thomas DJ, Marshall J, Ross Russell RW et al. Effect of haematocrit on cerebral blood-flow in man. Lancet 1977; II : 941-3.

20. Williams BO. Use and misuse of diuretics in the elderly. Prescr $J$ 1985; $25: 51-6$.

21. Caird FI (ed) Ant ihypertensive drugs, in: Drugs for the elderly. World Health Organization Regional Office for Europe, Copenhagen $1985 ; 73-7$. 
22. Chandhry AY, Bing RF, Castleden CM, Swales JD, Napier CJ. The effect of ageing on the response to furosemide in normal subjects. Eur J Clin Pharmacol 1984; 27 :303-6.

23. Schuster CJ, Weil MH, Besso J, Carpio M, Henning RJ. Blood volume following diuresis induced by furosemide. Am J Med 1984; 76 : 585-92.

24. Greenblatt DJ, Duhme DW, Allen MD, Koch-Weser J. Clinical toxicity of furosemide in hospitalized patients. A report from the Boston collaborative druq surveillance program. Am Heart $J$ 1977; $94: 6-13$.

25. Lowe J, Gray J, Henry DA, Lawson DH. Adverse reactions to furosemide in hospital in patients. Br Med J 1979; II : 360-2, 



\section{COURSE OF BLOOD PRESSURE AFTER CEREBRAL}

INFARCTION AND TRANSIENT ISCHAEMIC ATTACK

P.A.F. JANSEN, B.P.M. SCHIJLTE, E.F.J. POF.LS, F.W.J. GRIRNAU

Presented at 13th International Salzburg Conference on cerebrovascular disease, september 1986. 


\section{ABSTRACT}

In 63 patients, admitted for cerebral infarction or transient ischaemic attack (TIA), the blood pressure course was studied. The blood pressure before the event was studied retrospectively; 32 patients were normotensive, in 31 patients existed hypertension, with antihypertensive treatment in 15 of these cases. The blood pressure after the event was studied prospectively, and turned out to be risen in $67 \%$ of the patients on the day of admission. It fell in the first days after infarction or TIA, mainly on the second day, to a plateau level reached on the fifth day. Only 3 patients (5\%) remained hypertensive until discharge from the hospital. In 48 patients blood pressure values were available as measured two to six months after discharge, without a change in antihypertensive medication. Blood pressure appeared increased compared to the value measured before discharge. In 14 patients (29\%) hypertensive blood pressure figures were measured at that time. It is concluded that blood pressure is elevated in the acute phase of cerebral infarction and TIA, but falls spontaneously in the first days to normotensive levels in most patients; because blood pressure may increase again, measurements of blood pressure within the first months after discharge are needed. 
INTRODUCTION

The onset of stroke is usually accompanied with elevation of blood pressure. Most authors advise not to treat elevated blood pressure in the acute phase of ischaemic stroke, except in patients with hypertensive encephalopathy $1-3$. The reason not to treat post-stroke hypertension is that autoregulation may be impaired in the first weeks after stroke, relating cerebral blood flow directly to systemic blood pressure ${ }^{4}$; even a minor fall in blood pressure may cause a decrease in blood flow in the ischaemic area, aggravating cerebral ischaemia and enlarging the infarct. However, there is no general agreement about the management of hypertension in the acute phase of stroke $e^{5-6}$.

There are only a few reports in literature about the changes in blood pressure after stroke $7-10$. It is shown that after an early blood pressure elevation, tension falls spontaneously mainly in the first three days after the event, in all types of strokes. Blood pressure falls to or below premorbid levels.

We studied the changes in blood pressure measured before, in the first days after and a few months after cerebral infarction and transient ischaemic attack (TIA).

MATERIAL AND METHODS

Study design; patients

The blood pressure course was studied in 63 patients, admitted to a general hospital because of acute cerebral infarction ( $n=53$ ) or TIA $(n=10)$. Twenty one patients with cerebral infarction and three with TIA used antihypertensive treatment. This treatment remained unchanged during their stay in hospital. In none of the patients antihypertensive or diuretic drugs were started. The population studied comprised 38 women and 25 men aged $74 \pm 8$ years (mean $\pm S D$ ), range 51 to 89 years. Cerebral infarction or TIA was diagnosed according to the criteria of the WHO11. At admission the blood pressure was recorded with a sphygmomanometer in the emergency department, during the first three days at least every six hours in the neurology department, and every 12 hours from then on. This was done by trained nurses. The 
blood pressure values before infarction or TIA were measured two weeks to one year before stroke by the general practitioner.

The blood pressure values after discharge from the hospital were measured two or six months after infarction or TIA by the general practitioner or nursing home physician, all before an eventual change in antihypertensive or diuretic medication. Blood pressures are expressed as mean systolic or diastolic pressures ( \pm SD) or as mean arterial pressure (MAP):

MAP $=$ diastolic blood pressure $+1 / 3$ (systolic-diastolic blood pressure).

For statistical analysis paired and independent sample t-tests were used, respectively, for comparison of the MAP values of the first days after the event and for comparison of the MAP values of three patient groups (with pre-existing hypertension, with and without antihypertensive therapy, and with no pre-existing hypertension).

\section{RESULTS}

The spontaneous changes in blood pressure in the 63 patients are presented in Fig. 1. Before infarction or TIA mean blood pressure was $159 / 92+25 / 10 \mathrm{mmHg}$, with a MAP of $115 \pm 14 \mathrm{mmHg}$. Forty patients (63\%) were known to the general practitioner as hypertensive according to the criteria of the $W \mathrm{O}^{12}$ (i.e. systolic $>160$ and /or diastolic $>95 \mathrm{mmHg}$ ) before the event. Of these 40 patients, 16 received no antihypertensive therapy; of the 24 patients under treatment, 15 responded insufficiently to antihypertensive therapy.

At admission to the emergency department the highest blood pressure levels during stay in hospital were measured: $183 / 104 \pm 31 / 15 \mathrm{mmHg}$, MAP $130 \pm 19 \mathrm{mmHg}$. The first measured blood pressure in the neurology department was both systolic and diastolic considerably lower $(168 / 95 \pm 29 / 14 \mathrm{mmHg}$, MAP $120 \pm 18 \mathrm{mmHg})$. On the first day after infarction or TIA, 67\% had elevated blood pressure. The blood pressure fell spontaneously the following days, to a level of $141 / 81+18 / 8 \mathrm{mmHa}$, MAP $101 \pm 10 \mathrm{mHHg}$. Because blood pressure sometimes fluctuated markedly, the maximal, minimal and MAP measurements are also depicted in Fig. 1. The blood pressures measured on the first day (1) include the 
first blood pressure measured in the neurology department $(N)$, but not the blood pressure measured in the emergency department ( $F_{\text {) }}$. The greatest difference in MAP existed between the first and second day after stroke. The fall was significant $(p<0.001)$. The MAP on the fifth day and before discharge were nearly identical $(101 \pm 10 \mathrm{mmHg}$ and

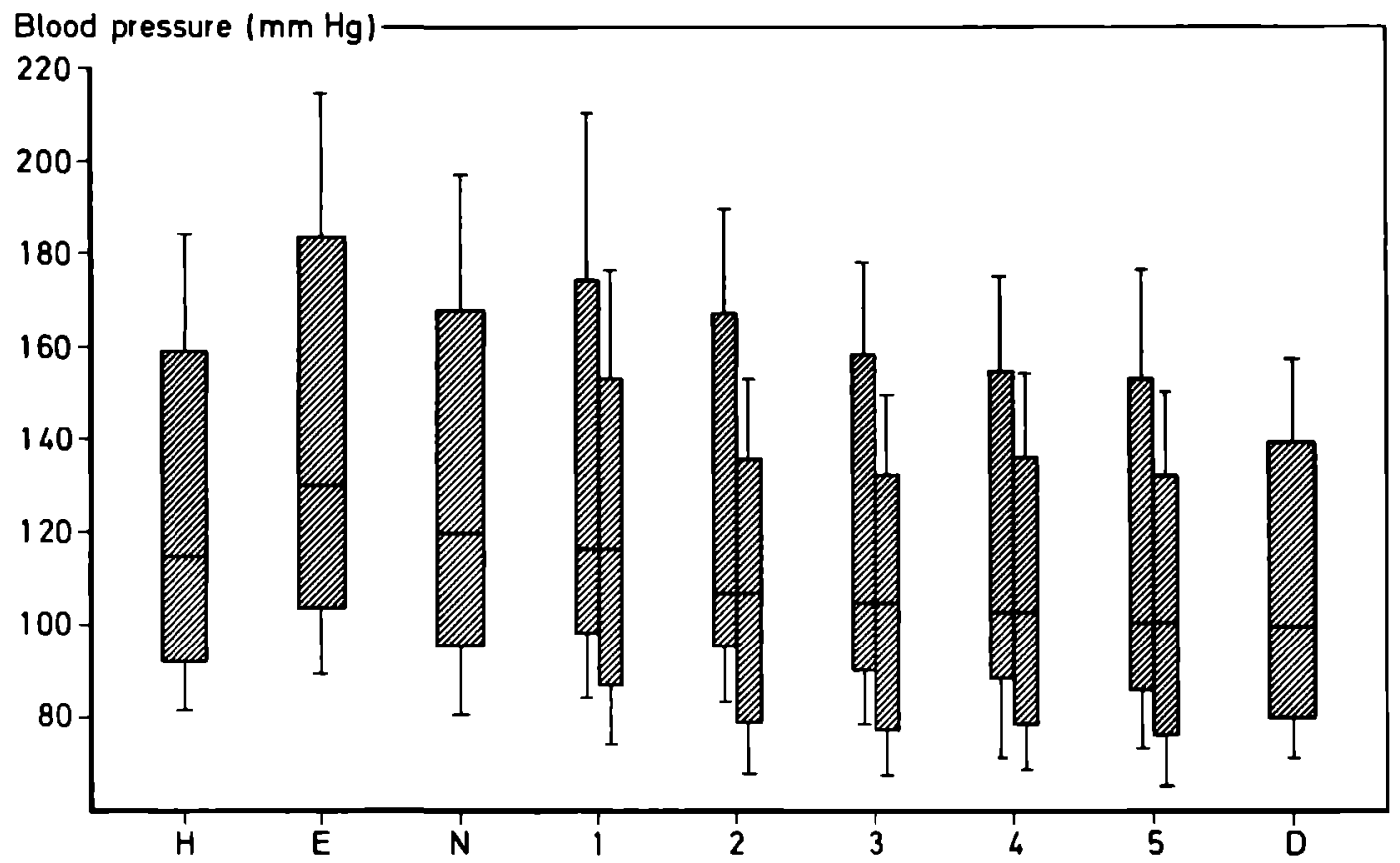

Fig. 1.

Course of systolic and diastolic blood pressure and MAP $(-)$ values (mean \pm SD) of the 63 patients in this study; blood pressures were measured 2 weeks to one year before the event at home $(H)$, in the emergency department (E), on the first to fifth day (1-5) and before discharge (D). N represents the first measurement in the neurology department. The maximal and minimal systolic and diastolic blood pressures of the first to fifth day are shown. The blood pressure measured in $E$ is not included in the blood pressure fiqures of the first day. 
$100 \pm 11 \mathrm{mHHg}$, respectively) and were considerably lower $(p<0.001)$ than the premorbid levels (MAP $115 \pm 14 \mathrm{mmHa}$ ).

At discharge only 3 patients (5\%) were still (slightly) hypertensive.

Apart from the blood pressure values measured at home, the MAP of the patients with TIA were at any time lower (although not significantly) than the MAP of the patients with an infarction (Fig. 2).

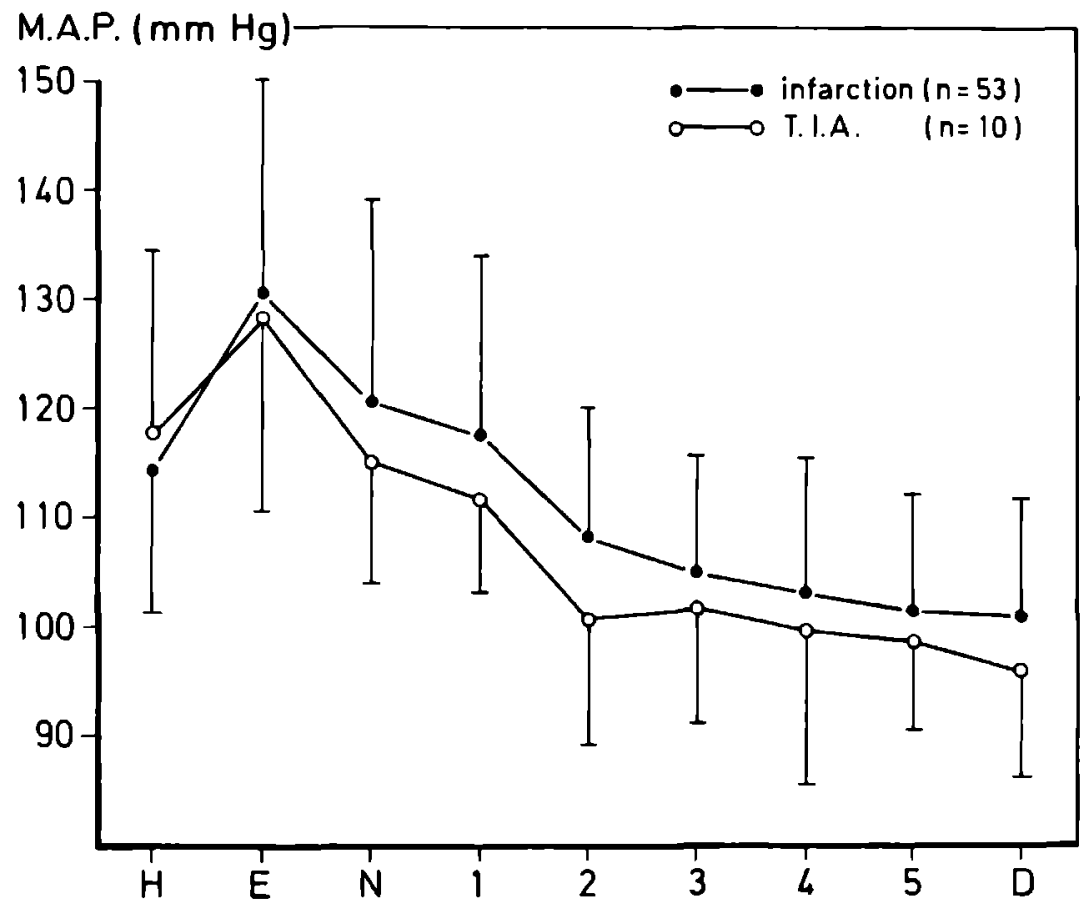

Fig. 2.

Course of MAP $( \pm S D)$ of the patients with cerebral infarction or TIA in this study. For explanation of the letters on the abscissa see Fig. 1 . 
Fig. 3 shows the blood pressure course of patients with pre-existing hypertension with antihypertensive treatment ( $n=24)$, with preexisting hypertension without antihypertensive treatment $(n=16)$ and without pre-existing hypertension $(n=23)$. In the first days after the event there was a striking parallel between the three curves. The MAP of the patients without pre-existing hypertension was at any point lower than the MAP of the hypertensive patients. Before the event, on the 4 th and 5 th day after it and before discharge this difference was significant $(p<0.05)$.

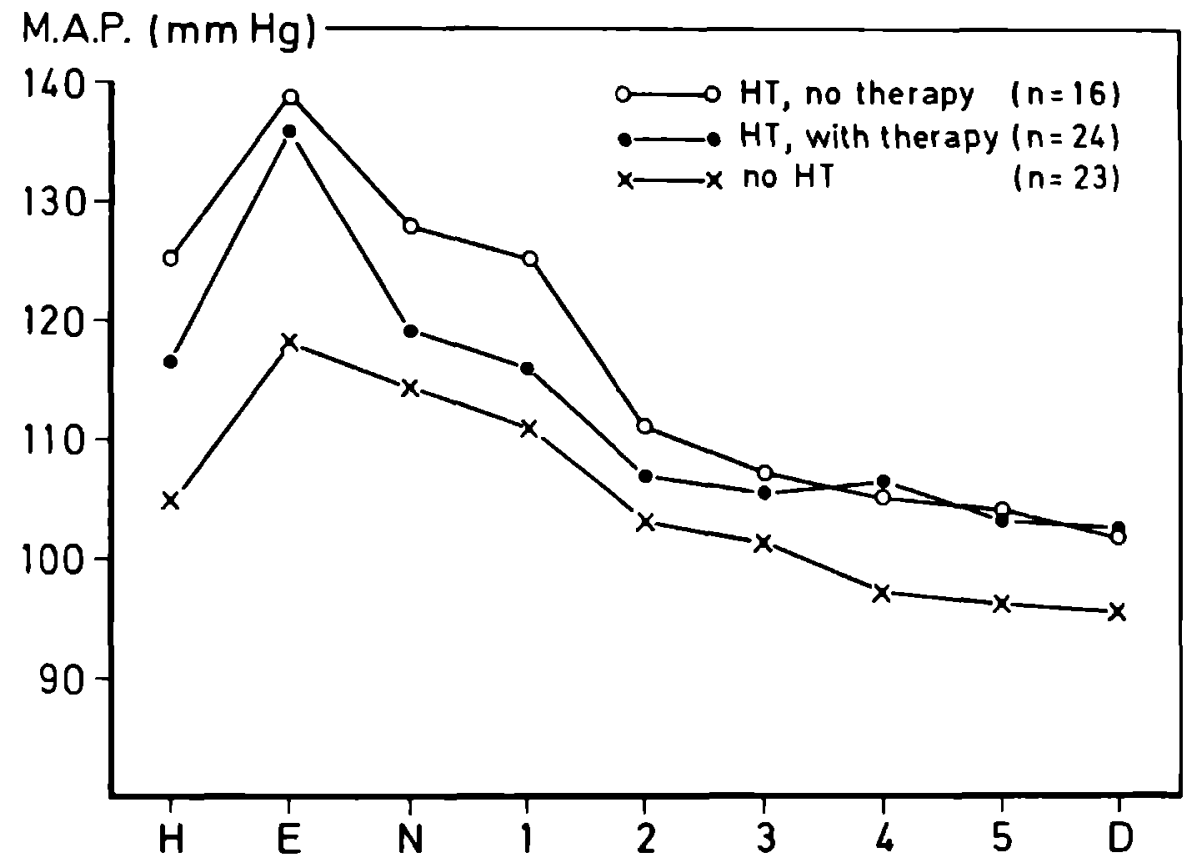

Fiq. 3 .

Course of MAP of the patient groups with pre-existent hyper-tension, with and without antihypertensive therapy, and without pre-existent hypertension. For explanation of the letters on the abscissa see Fig. 1. 
The patients were discharged to home $(n=51)$ or nursing home $(n=12)$. of 48 patients with infarction $(n=40)$ or TIA $(n=8)$ blood pressure data were available, measured two to six months after discharge from hospital; these patients had not changed their antihypertensive/ diuretic medication. The other patients had died, were lost to follow-up, or their data could not be used because of change in antihypertensive/diuretic medication. The course of the MAP of the 48 patients, measured before, in the first days after and two to six months after discharge is shown in Fig. 4.

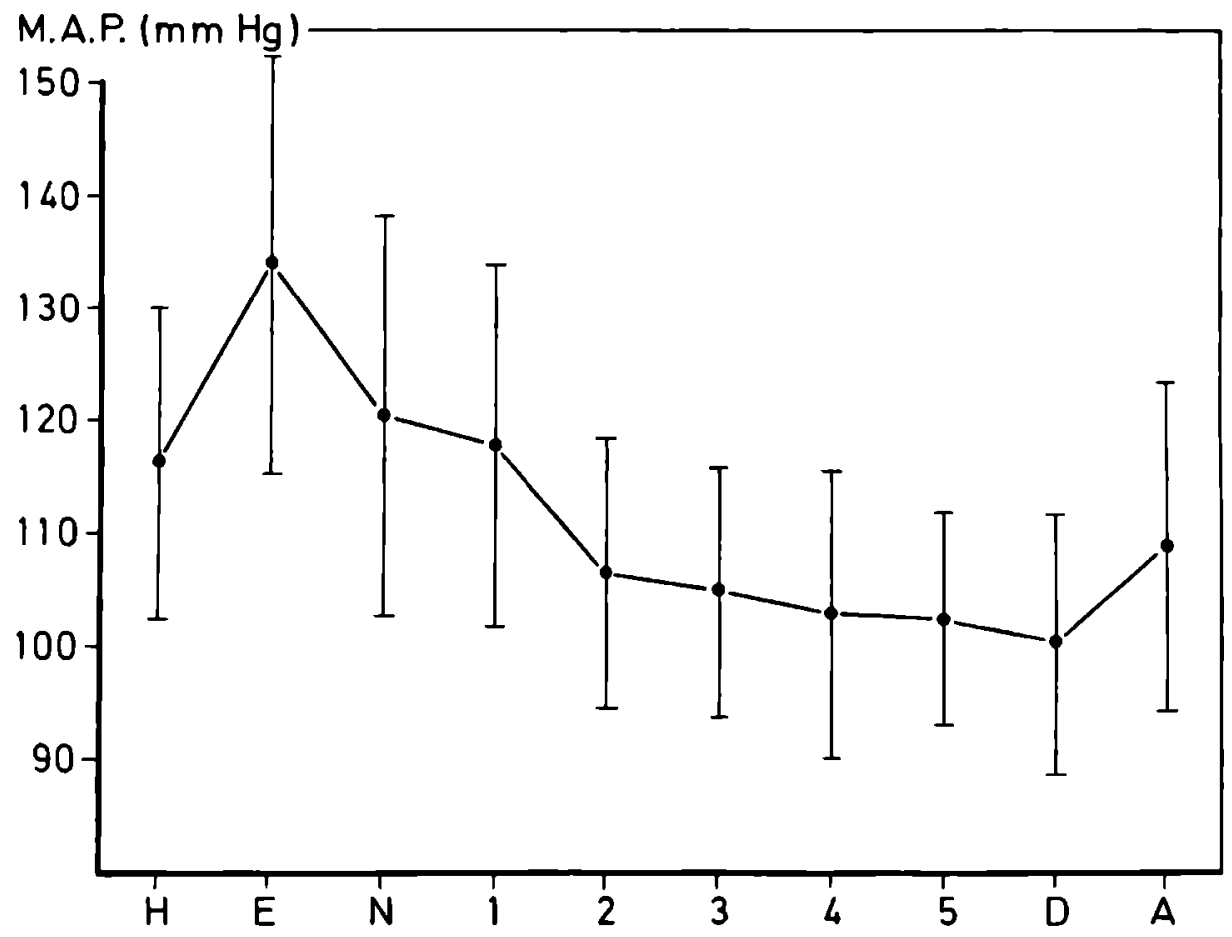

Fig. 4 .

Course of MAP $( \pm S O)$ of 48 patients with infarction $(n=40)$ or TIA $(n=8)$ measured before, directly after and two to six months after discharge from hospital (A). 
The MAP measured after discharge (A) was higher $(p<0.01)$ than that before discharge $(D)$, but still lower $(p<0.01)$ than the MAP measured before the event at home $(H)$. Of the 48 patients, 35 were known to the general practitioner with pre-existing hypertension. Twenty-three patients were on antihypertensive drugs; 26 patients had hypertensive blood pressure values (14 patients with treatment, 12 without). After the event and until discharge only three patients remained hypertensive (two received antihypertensive medication). Blood pressure measurements two to six months after discharge revealed hypertensive

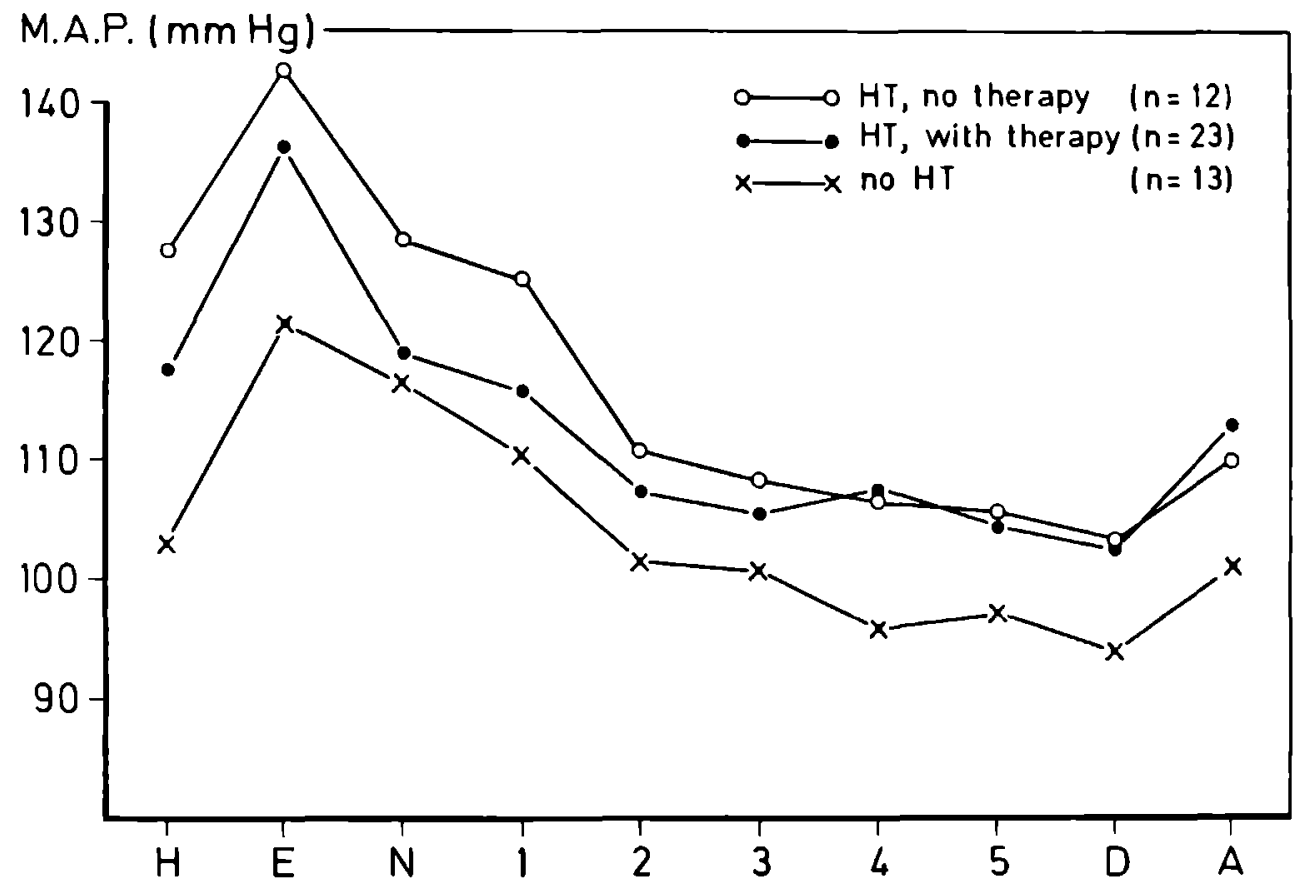

Fig. 5 .

Course of MAP in the three patient groups with pre-existent hypertension, with and without therady, and without pre-existent hypertension. 
blood pressures in 14 patients (from these, 9 patients were on ant $i$ hypertensive therapy). All patients with normotension before the event remained normotensive up to 2 to 6 months after the infarction or TIA. After discharge MAP returned to the premorbid level in the normotensive patients (Fig. 5). In the patients with pre-existent hypertension and antihypertensive therapy the MAP level also rose after discharge, but remained slightly lower than the level before the event; the difference $(113 \pm 15 \mathrm{mmHq}$ vs $118 \pm 12 \mathrm{mmHg})$ was not significant. The MAP level of the patients with pre-existent hypertension without antihypertensive medication, increased after discharge to a mean of $110( \pm 15) \mathrm{mmHg}$; compared to the pre-morbid MAP level $(127 \pm 9)$ their blood pressure was still siqnificantly lower $(p<0.01)$.

\section{DISCUSSION}

The change in blood pressure after stroke without specific antihypertensive therapy was studied in 334 patients by Wallace and Levy 8 . For all types of stroke they found high blood pressure values (systolic as well as diastolic) at admission; a spontaneous decrease in blood pressure to normotensive levels was seen within the first ten days after admission in all categories of stroke. The patients with intracerebral haemorrhage had highly variable blood pressures; in this patient group the systolic blood pressure decreased, but the diastolic blood pressure did not change in the first days after stroke.

We studied 63 patients with cerebral infarction ( $n=53)$ or TIA $(n=10)$ as to the spontaneous blood pressure course before, anddirectly after the event and two to six months after discharge from hospital. Our results are comparable with those reported by Hallace; in most patients we found hypertensive blood pressure levels after infarction or TIA; within a few days blood pressure fell to normotensive levels without change in antihypertensive medication. The highest blood pressure values were recorded in the emergency department. This may be due to the stress of the event. In view of the difference in blood pressure between the emergency department and the neurology depart- 
ment it is of importance to transfer patients with stroke to the neurology department as soon as possible, and moreover it seems advisable to decide on antihypertensive intervention, if any or ever, only on the basis of values obtained in the neurological ward.

The most marked fall in blood pressure occurred from the first to the second day after the event; the difference was statistically sianificant. On the second to fifth day a further gradual fall in blood pressure was seen to plateau values in the order of the blood pressure value measured before discharge from the hospital. This level was significantly lower than premorbid levels.

Clearly the patients with TIA were admitted because of long duration of the event. After the TIA they had lower blood oressures than the infarction group; one might therefore conclude that the severity of cerebral ischaemia apparently determines the degree of increase in blood pressure after the event, possibly as a natural defense mechanism for the benefit of blood flow in the ischaemic area.

After discharge blood pressure rose again, but remained below premorbid levels. Especially the patients with previous hypertension and no antihypertensive therapy had MAP levels (measured two to six months after the event) far below premorbid levels. We have no complete explanation for this finding, but it may at least partly result from changes made by the patients in their way of life. However, this group was small. It should be emphasized that blood pressure measurements are necessary in the first months after discharge, because hypertension can return and antihypertensive treatment can prevent stroke recurrence 13,14 , although not in the elderly 15,16 .

Since antihypertensive treatment in the acute phase of stroke might be dangerous 17 , and the blood pressure falls spontaneously after stroke, mainly between the first and second day, as shown by our results and other studies $7-10$, no additional antihypertensive treatment should be instituted in the first days after stroke unless signs of hyoertensive encephalopathy are present. Frequently, antihypertensive medication can even be stopped during the stay in hospital because the blood pressure normalizes spontaneously; 
however, blood pressure measurement after discharge is needed because patients with a normalized post-stroke blood pressure during their stay in hospital may become hypertensive again after a few months. 


\section{REFERENCES}

1. Yatsu FM, Zivin J. Hypertension in acute ischemic strokes. Not to treat. Arch Neurol 1985; 42 : 999-1000.

2. Kistler JP, Ropper AH, Heros RC. Therapy of ischemic cerebral vascular disease due to atherothrombosis. N Engl J Med 1985;Part I; 311 : 27-34; Part II; 311 : 100-5.

3. Buananno F, Toole JF. Management of patients with established ("completed") cerebral infarction. Stroke 1981; $12: 7$.

4. Johnson RH, Lambie DG and Spalding JMK (eds) Neurocardiology.The interrelationship between dysfunction in the nervous and cardiovascular systems; Strokes, WB Saunders, London 1984; 261-322.

5. Spence JD, Del Maestro RF. Hypertension in acute ischaemic strokes; treat. Arch Neurol 1985; 42 : 1000-2.

6. Hachinski $V$. Hypertension in acute ischaemic strokes. Arch Neurol 1985; 42 : 1002.

7. de Faire $U$, Britton $M$, Helmers $C$, Wester PO. Blood pressure during the acute phases of cerebrovascular disease. Acta Med Scand Supp I 1978; $621: 27$.

8. Wallace JD, Levy LL. Blood pressure after stroke. JAMA 1981; 246 : 2177-80.

9. Loyke HF. Lowering of blood pressure after stroke. Am J Med Sci 1983; $286: 2-11$.

10. Schulte BPM, Leyten ACM, Herman B. Differing aspects of prestroke and post-stroke hypertension. J Neurol 1985; 232 : 186.

11. Hatano S. Control of stroke in the community - methodological considerations and protocol of WHO stroke Register. Working document for meeting community control of stroke and hypertension. Geneva 6-13 December 1973 (WHO document no. CVn/S/73.6 Rev. 1).

12. WHO. Report of a WHO Expert Committee, Arterial hypertension.WHO Techn Rep Ser 1978; 628.

13. Marshall J. A trial of long-term hypertensive therapy in cerebrovascular disease. Lancet 1964; I : 10-2.

14. Beevers DG, Fairmann MJ, Hamilton M, Harpur JE. Antihypertens ive treatment and the course of established cerebrovascular disease. Lancet 1973; I : 1407-9. 
15. Hypertension - Stroke Co-operative Study Group. Effect of antihypertensive treatment on stroke recurrence. JAMA 1974; 229 : 409-18.

16. Carter $A B$. Hypotensive therapy in stroke survivors. Lancet 1970; I : 485-9.

17. Britton M, de Faire U, Helmers C. Hazards of therapy for excessive hypertension in acute stroke. Acta Med Scand 1980; 207 : 253-7. 


\title{
BLOOD PRESSURE AND BOTH VENOUS AND URINARY CATECHOLAMINES AFTER CEREBRAL INFARCTION
}

\author{
P.A.F. Jansen, Th. Thien, F.W.J. Gribnau, B.P.M. Schulte, \\ J.J. Willemsen, K. Lamers, E.F.J. Poels,
}




\section{ABSTRACT}

Blood pressure, both venous and urinary catecholamines and olasma renin activity (PRA) were studied in 10 patients ( 6 men and 4 women, mean aqe $70 \pm 10$ years) on the first three days after cerebral infarction. Blood pressure fell siqnificantly $(p<0.02)$ on the second and third day after stroke. There was a small but sianificant ( $p<0.01)$ decrease in plasma epinephrine concentration on the third day. The norepinephrine values remained constant on the three days. The PRA showed a significant $(p<0.01)$ rise on the third day. No significant correlation was detected between the course of the blood pressure and the plasma catecholamines or PRA. When blood pressure was correlated with the urinary catecholamines, however, a significant correlation with epinephrine $(r=0.44 ; p<0.05)$ and dopamine $(r=0.44 ; p<0.05)$ but not with norepinephrine $(r=0.06 ; p>0.05)$ was found. We conclude that the changes in blood pressure after stroke are at least partly mediated by the changes in catecholamine production. 
INTRODUCTION

In the acute phase of stroke blood pressure is often increased 5,12 , 18,21 . During the first days after the event blood pressure decreases spontaneously, mainly between the first and the second day, to a mean baseline level, that is reached on the average on the fifth day. Post-stroke hypertension is present in all types of stroke. However, in the case of cerebral haemorrhage the highest blood pressure levels were found, whereas after cerebral infarction the blood pressure increase was smaller21; in both cases the fall in blood pressure after the event showed a similar pattern.

The cause of post-stroke hypertension is not clear; the stress of the event and neuronal (dys)regulation of blood pressure have been suggested ${ }^{3,13}$. In the first days after cerebral haemorrhage plasma epinephrine (E) and norepinephrine (NE) concentrations were found extremely high 1,14; on the first day after cerebral infarction and, to lesser extent, after transient ischaemic attacks, increased values of $E, N E$ and dopamine concentrations have also been reported ${ }^{15}$.

We studied the relationship between blood pressure levels and plasma concentrations of $F, N E$ and renin activity (PRA) on the first three days after cerebral infarction. We also considered the relationship between blood pressure and the urinary excretion of $E, N E$ and dopamine.

METHODS

Ten patients ( 6 male, 4 female) with cerebral infarction according to the criteria of the WHOlO were selected. The mean age ( + SD) was $70+10$ years. All patients gave their informed consent.

Four patients used anticoagulants, 2 diuretics and 1 a bronchodilator. The other 3 patients used no medication. During the study period medication had not been changed. On the first, second and third day after admission at $09.00 \mathrm{a.m}$. an intravenous catheter was placed in an antecubital vein, while the patient was kept in a recumbent position for at least 30 minutes. Then blood was collected for $E$ and $N E$ into an ice-cold tube containing $0.1 \mathrm{ml}$ blood additive $(0.25 \mathrm{~mol} / 1 \mathrm{EGTA}, 0.20 \mathrm{~mol} / 1 \mathrm{GSH}$, in distilled water and brought to 
$\mathrm{pH} 7.4$ with $5 \mathrm{~mol} / 1 \mathrm{NaOH}$ ) and for PRA (EDTA tube). The tubes were capped, gently mixed and centrifuged at $4^{\circ} \mathrm{C}$ as soon as possible. E and NE were measured as described by Hoffmann et al.11, PRA with a RIA method 4 . The reference values ( $\pm S D$, range) of $E, N E$ and PRA for normal adults in our laboratory are $0.165 \pm 0.05 \mathrm{nmol} / 1(0.06-0.30)$, $1.13 \pm 0.42 \mathrm{nmol} / 1(0.60-2.20)$ and $<2.78 \mathrm{ng} / 1 / \mathrm{s}$ respectively. Directly after blood collection blood pressure was measured with a sphygmomanometer by the investigator (PJ).

Blood pressure was also measured every six hours by trained nurses during the study period. Blood pressures are expressed as svstolic, diastolic and mean arterial pressure (MAP). MAP is the sum of the diastolic and $1 / 3$ of the pulse pressure. Twenty-four hour urine was collected for creatinine, sodium, $E, N E$ and dopamine measurement. In 6 patients complete collection of urine was not possible due to incontinence. All urine values arè therefore expressed per mol creatinine.

Urinary concentrations of catecholamines were measured using a modified method of westerink et al.22. The reference values of $E, N E$ and dopamine per mmol creatinine are 0.5-4.2 nmol, 5-34 nmol and 40-160 nmol respectively.

For statistical comparison Wilcoxon signed rank test and Spearman's rank correlation were used. A p-value of less than 0.05 was accepted as level of significance. Results are expressed as mean $+\mathrm{SE}$, unless stated otherwise.

\section{RESULTS}

The systolic, diastolic and MAP values of the 10 patients, measured during the first three days after cerebral infarction at the time of blood collection and the mean of the four nurse readings, are presented in Figure 1. There was a significant $(p<0.02)$ fall in systolic as well as in diastolic blood pressure from $161 / 96 \pm 8 / 4$ on the first day to $149 / 90 \pm 6 / 5$ on the second day, and to $140 / 84 \pm 5 / 5 \mathrm{mmHg}$ on the third day. The blood pressures measured at the time of blood collection were never significantly different from the values measured throughout the day. 
In Figure 2 the mean values of $E$, NE and PRA of the first three days after cerebral infarction are presented. The plasma concentration of $E$ was the highest on the second day with $0.55 \pm 0.11 \mathrm{nmol} / 1$. The concentration of $E$ on the third day was $0.41 \pm 0.09 \mathrm{nmol} / 1$, which was significantly different $(p<0.01)$ from that on the second day.

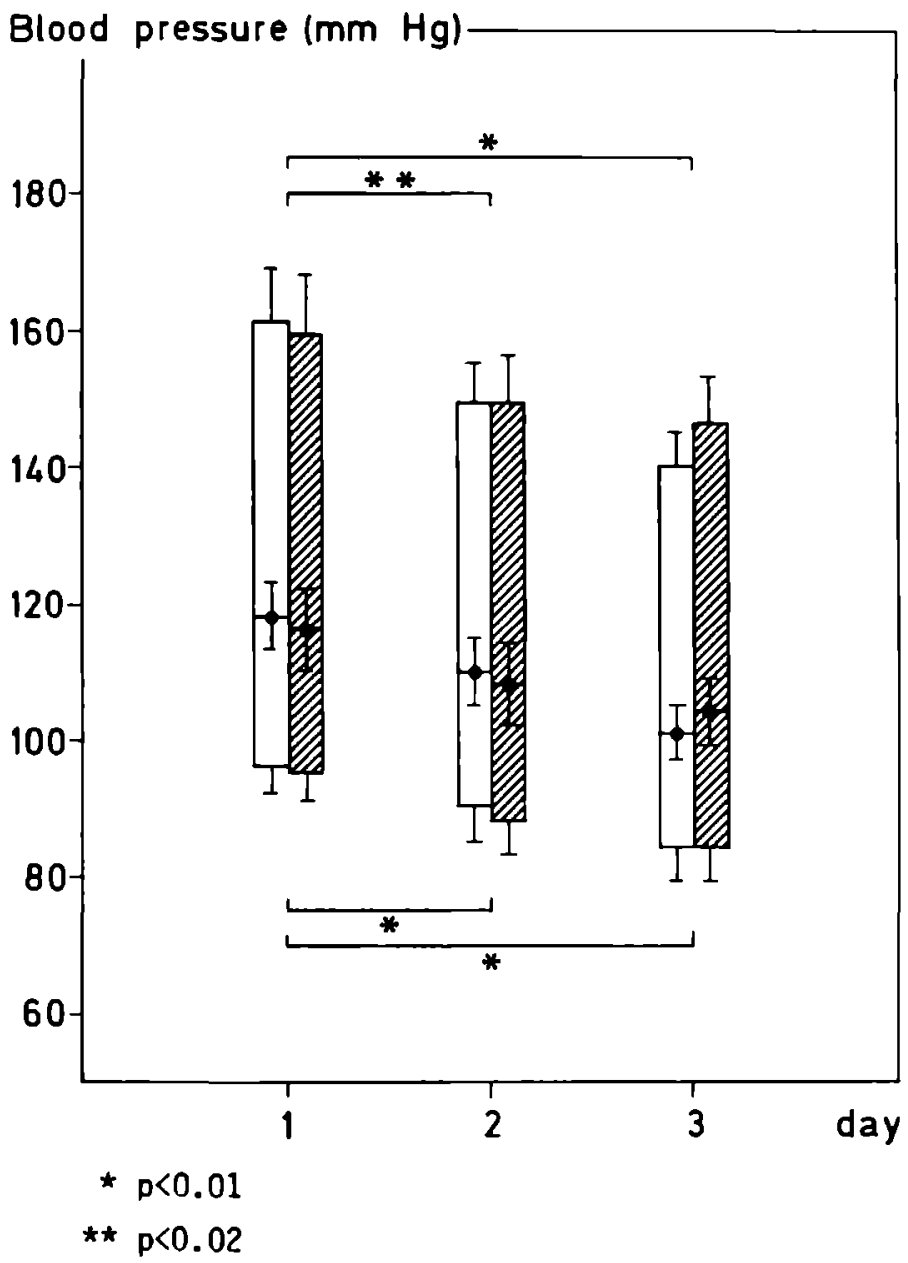

Fig. 1 .

SystoTic, diastolic and MAP values (mean $\pm S E$ ) in 10 patients, measured the first three days after cerebral infarction, at the time of blood collection (hatched bars) and throughout the day (open bars). 
The concentration of $N E$ on the three days was nearly constant: $2.68 \pm 0.35,2.76 \pm 0.35$ and $2.69 \pm 0.34 \mathrm{nmol} / 1$ respectively. There was an increase in PRA from $0.17 \pm 0.03$ on the first day, to $0.22 \pm 0.04$ on the second day, to $0.38 \pm 0.06 \mathrm{ng} / 1 / \mathrm{s}$ on the third day. The PRA was significantly $(p<0.01)$ increased on the third day; the concentration was more than doubled on that day as compared with the first day after cerebral infarction. No significant correlation was found between MAP measured at time of blood collection (30 measurements), and $E$ $(r=0.36)$, NE $(r=0.06)$ and PRA $(r=-0.31)$, respectively. The urinary concentrations, expressed per mmol creatinine, of sodium, $E, N E$ and dopamine are summarized in Table I. Due to incontinence in 5 patients

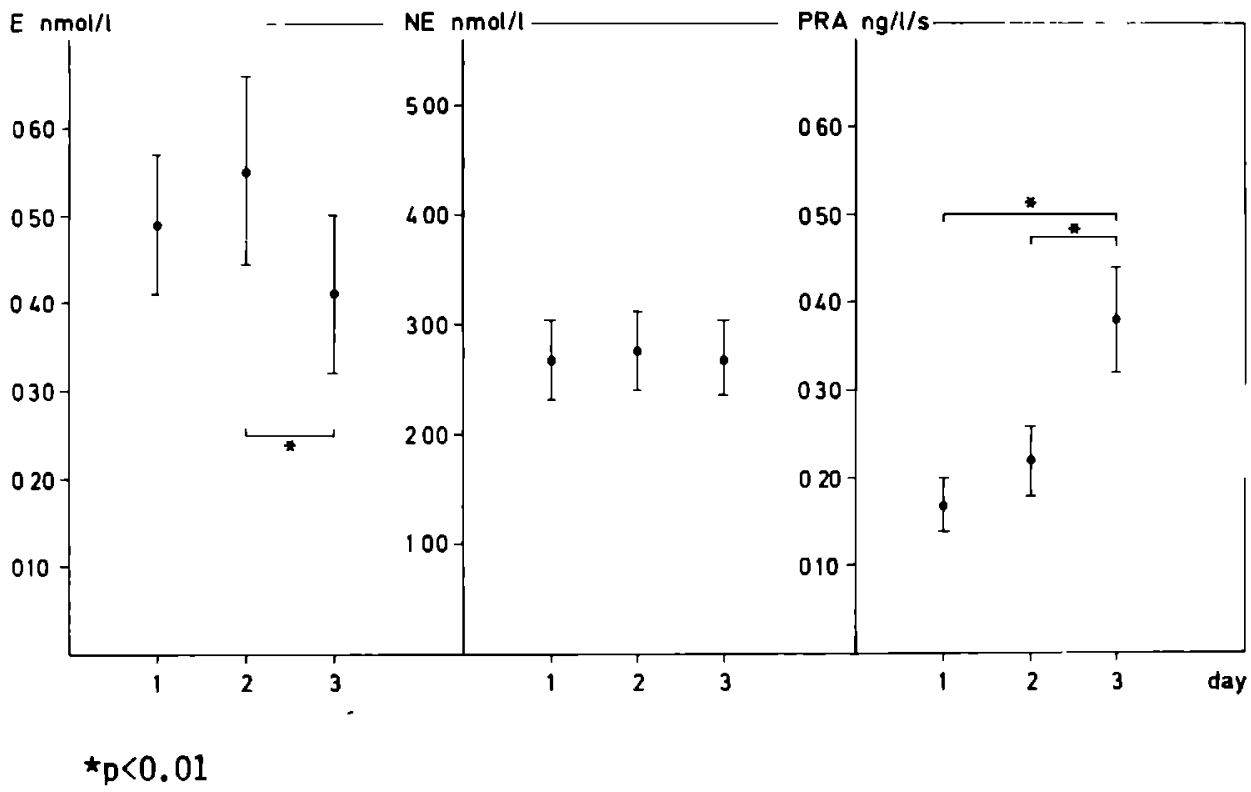

Fig. 2 .

$\bar{P}$ lasma concentrations (mean $\pm S E$ ) of epinephrine (E), norepinephrine (NE) and renin activity (PRA) in the 10 patients studied 
TABLE I

URINARY CONCENTRATIONS (MEAN +SE) OF SODIUM AND CATECHOLAMINES, EXPRESSED PER MMOL CREATININE, IN THE 10 PATIENTS STUDIED

$$
\text { day } 1(n=7) \quad \text { day } 2(n=8) \quad \text { day } 3(n=8)
$$

Sodium

$\mathrm{mmol} / \mathrm{mmol}$

$6.7 \pm 1.2$

$7.8 \pm 1.9$

$6.1 \pm 0.9$

Epinephrine

nmol/mmo 1

$3.6 \pm 0.8$

$4.3 \pm 1.0$

$2.5 \pm 0.6$

Norepinephrine nmol/mmol

$32 \pm 5$

$29 \pm 4$

$26 \pm 4$

Dopamine

$\mathrm{nmol} / \mathrm{mmol}$

$140 \pm 26$

$101 \pm 17$

$107 \pm 14$

the 24 hour urine collection was not obtained for one day and in 1 patient for two days. When the mean daily MAP values were correlated with the urinary catecholamine excretion (23 measurements), a modest but significant correlation was found for $E(r=0.44 ; p<0.05)$ and dopamine $(r=0.44 ; p<0.05)$, but not for NE $(r=0.06)$.

\section{DISCUSSION}

The early increase and spontaneous decrease of blood pressure after stroke is still unexplained. The present study shows that the course of blood pressure after cerebral infarction is not significantly related to the venous plasma concentrations of $E$, NE or PRA. While blood pressure fell in all patients, a nearly constant level of NE was found during the three days after cerebral infarction. Most of the patients studied were elderly, and plasma levels of NE are known to increase with age ${ }^{9}$. Moreover, elderly subjects show a greater rise in plasma NE in response to an uniform stress ${ }^{2,17}$. The high NE concentrations are therefore difficult to interpret. Meyers et a 1.15 reported increased plasma $E, N E$ and dopamine concentrations after cerebral infarction; the difference from a control group could not be explained by age, blood pressure, heart rate, stress or severity of stroke; in their material they found stable mean values on the first three days after the event for both $E$ and $N E$. In contrast, we found a decrease of $E$ in both plasma and urine on the third day. 
For the increase of PRA on the third day, present in all 10 patients, we have no explanation; since the urinary sodium excretion was not different on the three days after cerebral infarction, an altered salt intake or an effect of diuretics (in 2 patients only) cannot have influenced the results. Smith 19 suggested a relationship between hypertension after carotid endarterectomy and renin production by the brain. Ganten et al, 7,8 reported that the brain renin-angiotensin system is isolated from the peripheral renin-angiotensin system; brain renin appeared not to leak in the periphery. A parallel production of brain and peripherally produced renin is, however, suggested ${ }^{19}$. In case of cerebral ischaemia the brain renin production is increased and, due to the parallelism, the peripheral renin production may be increased too. Therefore, the rise in PRA we found on the third day may be a late consequence of the cerebral ischaemia. Elevation of catecholamine excretion after stroke is well known, but the explanation remains uncertain $6,16,20$. The relation we found between MAP and urinary excretion of $E$ and dopamine respectively, suggests that the early increase and spontaneous fall in blood pressure after cerebral infarction is mediated at least in part by the altered production of $E$ and dopamine. Like Meyers 15 , we found stable concentrations of NE and no relation with blood pressure.

In conclusion we found that the decrease of blood pressure on the first days after cerebral infarction was related to urinary excretion of $E$ and dopamine, but not to NE concentration. We also found a doubling of the PRA on the third day after cerebral infarction as compared with the first day, possibly as a late consequence of the cerebral ischaemia. 
REFERENCES

1. Benedict $C R$, Loach $A R$. Sympathetic nervous svstem activity in patients with subarachnoid hemorrhage. Stroke 1978; $9: 237-44$.

2. Christensen NJ. Catecholamines and sympathetic nervous activity in the elderly. Act Med Scand 1982; Suppl $676: 52-63$.

3. Conomy JP, Barnes KL, Ferrario CM. The brain and arterial hypertension: new direction in an old relationship. Neurol 1978; 28 : 1203-5.

4. Drayer JIM, Benraad ThJ. The reliability of the measurement of plasma renin activity by radioimmunoassay. Clin Chim Acta 1975; 61 : 309-24.

5. Faire $U$ de, Britton $M$, Helmers $C$, Wester PO. Blood pressure during the acute phases of cerebrovascular disease. Acta Med Scand 1978; Suppl 88 : 621-7.

6. Feibel JH, Baldwin CA, Joynt RJ. Catecholamine-associated refractory hypertension following acute intracranial hemorrhage: control with propranolol. Ann Neurol 1981; 9 : 340-3.

7. Ganten D, Speck $G$. The brain renin-angiotensin system: a model for the synthesis of peptides in the brain. Biochem Pharmacol 1978; 27 : 2379-89.

8. Ganten D, Minnick JE, Granger $P$ et al. Angiotens in forming enzyme in brain tissue. Science $1971 ; 173: 64-5$.

9. Goldstein D, Lake CR, Chernow B et al. Age-Dependency of hypertensive-normotensive differences in plasma norepinephrine. Hypertension 1983; 5 : 100-4.

10. Hatano S. Control of stroke in the community - methodological considerations and protocol of WHO stroke Register. Working document for meeting on community control of stroke and hypertension. Geneva 6-13 December 1973 (WHO document no. CVD/S/73.6 Rev. 1).

11. Hoffmann JJML, Willemsen JJ, Lenders JWM, Benraad ThJ. Reduced imprecision of the radioenzymatic assay of plasma catecholamines by improving the stability of the internal standard. Clin Chim Acta 1986; 156 : 221-6.

12. Loyke HF. Lowering of blood pressure after stroke. Am J Med 1983; 286 : 2-11. 
13. Melamed E, Cooper G, Saltstein E, Globus M. Transitory elevations in arterial blood pressure in patients with acute cerebral ischemia: incidence, natural history and clinical significance. Abstracts 2nd International Symposium on Brain-Heart Relationship, Jerusalem; 1983.

14. Meyer JS, Stoica E, Pasen I, Shimazu K, Hartmann A. Catecholamine concentrations in CSF and plasma of patients with cerebral infarction and haemorrhage. Brain 1973; 96 : 277-88.

15. Meyers MG, Norris JW, Hachinski VC, Sole NJ. Plasma norepinephrine in stroke. Stroke $1981 ; 12: 200-4$.

16. Neil-Dwyer G, Cruickshank J, Stott A, Brice J. The urinary catecholamine and plasma cortisol levels in patients with subarachnoid haemorrhage. J Neurol Sci 1974; 22 : 375-82.

17. Palmer GJ, Ziegler MG, Lake CR. Response of norepinephrine and blood pressure to stress increases with age. J Gerontol 1978; $33: 482-7$.

18. Schulte BPM, Leyten ACM, Herman B. Pre-stroke and immediate poststroke hypertension: neuroepidemioloqical data. In: Meyer JS, Lechner $H$, Reivick M, Ott $E$ (eds) Cerebral Vascular Disease 5 (12th Salzburg Conference). Excerpta Medica, Amsterdam-New YorkOxford 1985; 286.

19. Smith BL. Hypertension following carotid endarterectomy: the role of cerebral renin production. J Vasc Surg 1984; 1 : 623-7.

20. Stoica E, Enulescu 0. Abnormal catecholamine urinary excretion after emotional stimulus in patients with cerebral hemorrhage. Stroke $1981 ; 12$ : 360-6.

21. Wallace JD, Levy LL. Blood pressure after stroke. JAMA 1981; 246 : 2177-80.

22. Westerink BHC, Bosher FJ, O'Hanlon JF. Use of Alumina, Sephadex G-10 and Ion-exchange Columns to purify samples for determination of epinephrine, norepinephrine, dopamine, homovanillic acid, and 5-hydroxyindoleacetic acid in urine. Clin Chem 1982; $28: 1745-8$. 
CHAPTER 9

SUMMARY AND CONCLUSIONS

ANTIHYPERTENSIVE TREATMENT AS A POSSIBLE

CAUSE OF STROKE IN THE ELDERLY 
The elderly often suffer from multiple pathology and therefore they consume many drugs, frequently at the same time. Due to polypharmacy, interactions of the drugs, and altered pharmacokinetics and pharmacodynamics in the elderly, a twofold increase of adverse drug reactions (ADR) is seen in patients over 70 years of age as compared with the young. Knowledge of possible drug interactions and of geriatric pharmacology is therefore of importance to prevent iatrogenic disease in the aged.

All drugs exert side effects. Recognition of a clinical sign as unwanted drug effect is sometimes easy, but more frequently it is difficult to assess an AOR. When a drug is prescribed to prevent a disease, it is difficult to prove that the disease is a result of an unwanted effect of the prescribed drug. We studied the possibility of stroke as ADR to antihypertensive treatment.

In Chapter 1 the incentive for this study is described. The aim is to answer the question whether stroke as $A D R$ to antihypertensive treatment really occurs; if so, which drugs are responsible for it; are the elderly especially at risk to develop this ADR, and what is its incidence in a hospitalized stroke population.

Before side effects of drugs can be assessed and treated, they have to be thought of. When a clinical sign is suspected as ADR, it has to be assessed and the relation between the drug and the suspected adverse reaction can be described as unlikely (or doubtful), possible, probable, or definite. This assessment is notoriously difficult. There has been a number of methods and algorithms published for assessing causality. However, when different methods are used for the same cases, they do not necessarily yield the same results.

In Chapter 2 stroke as side effect of antihypertensive treatment is assessed using two important methods. Only on the basis of time relationship between start of the drug and the event, the ADR was assessed as possible. Major features of the methods, like dechallenge and rechallenge, were of no value because stroke is often irreversible. Moreover, a good alternative possible cause of stroke is always 
present because hypertension is known to be the most important risk factor for stroke. However, the patients with stroke we suspected of having an ADR due to their antihypertensive treatment, all showed a remarkable and unexpected fall in blood pressure after the event and they had signs of haemoconcentration (high haematocrit values), factors pointing at stroke as ADR; these factors could not be implicated in any part of the methods. It was concluded that the commonly used algorithms and methods are not suitable in assessing antihypertensive treatment as a cause of stroke.

Chapter 3 reviews the literature on reported cases of drug-induced cerebral ischaemia. We detected forty-four such cases. The patients showed signs of cerebral ischaemia such as confusion, drowsiness, collapse and stroke, induced by all kinds of antihypertensive drugs such as diazoxide, nitroprusside, high-ceiling diuretics, methvldopa, vasodilators, beta-blocking drugs and angiotensin-converting enzyme inhibitors. Relating the fall in mean arterial blood pressure (MAP) induced by the drugs to the age of the patients, it was seen that the young showed a marked fall of MAP, while in the elderly a rather small fall of MAP may result in cerebral ischaemia. It was concluded that the aged are especially at risk to develop cerebral ischaemia as ADR to antihypertensive drugs. Suggested explanations could be the impairment of baroreceptor sensitivity, possible failure of cerebral autoregulation of the brain, and reduction of cerebral blood flow in the elderly as compared with the voung.

Chapter 4 discusses an inquiry by questionnaire. A questionnaire was sent to all medical directors of Dutch nursing homes $(n=322)$, because it was assumed that many patients with stroke, induced by hypotensive drugs, might be found in the populations of nursing home patients. The response was $55 \%$.

Thirty patients with signs of cerebral ischaemia or stroke developing within two weeks of the start of antihypertensive or diuretic drugs were reported by 25 physicians. All kinds of such druas were reported, but furosemide and methyldopa were mentioned especially. Nine of the thirty patients were well documented with full data on blood pressure measured immediately after the event and compared with pre- 
treatment levels. The case histories of these elderly patients are presented. It was concluded that antihypertensive treatment in the elderly should start with a small dose of an appropriate drug, the aim being to reduce blood pressure gradually.

In Chapter 5 a study among patients admitted to a general hospital because of cerebral infarction or transient ischaemic attack (TIA) is presented. One-hundred and seventy-eight patients were studied. Data on blood pressure values measured by the general practitioner a few days to one year before the event, were available on 100 of these patients. Only these 100 patients were included in the study. Seven of the 100 patients had had a change in antihypertensive or diuretic treatment within 3 weeks before the event. They all suffered a stroke. Three had started furosemide because of hypertension, two because of congestive heart failure; one patient had had an increase in furosemide dosage because of oedema of one leg and one had had an increase in Adelphan-Esidrex ${ }^{R}$ dosage because of persistent hypertension. Seventy-one of the 100 patients had an increase of MAP and twenty-nine a fall after the event as compared with pre-morbid levels. The 3 patients who had started furosemide because of hypertension showed the most marked fall of MAP $(18,19$ and $22 \%$ respectively). The patient with an increased Adelphan-Esidrex ${ }^{R}$ dosage had a fall in MAP of $12 \%$. These four patients showed signs of haemoconcentration (high haematocrit values). It was believed that the medication change was a factor contributing to the stroke in these elderIv patients. The other 3 patients had a smaller decrease (10\%) or even increase (5 and 15\%) in MAP, and no signs of haemoconcentration were present. Since other risk factors for stroke were also present in these patients (atrial fibrillation with high ventricular rate and cessation of acenocoumarol one week before the event), the relation between medication change (start of furosemide because of congestive heart failure and increased furosemide dosage because of oedema of one leg) and stroke was considered as less likely. It was concluded from this study that especially high-ceiling diuretics such as furosemide, if used in the treatment of hypertension, may induce hypovolaemia and hypotension resulting in cerebral ischaemia. 
In Chapter 6 a study on one category of the 100 patients described in Chapter 5 is presented; this category comprised only patients with cerebral infarction and using antihypertensive or diuretic drugs; this gave a series of 54 patients. The case histories of the 3 patients who had started furosemide because of hypertension are given. It is pointed out that drug-induced cerebral ischaemia may develop in some $6 \%$ of all hospitalized stroke patients treated with hypotensive drugs.

After stroke, the blood pressure is usually increased. It is still being debated whether post-stroke hypertension has to be treated. There are reports showing that lowering of post-stroke hypertension may be danqerous and can aggrevate cerebral ischaemia. We studied the spontaneous course of blood pressure in patients admitted for cerebral infarction and TIA. This study is presented in Chaoter 7 . In 42 of the 63 patients studied blood pressure was increased on the day of admission. During the study period antihypertensive or diuretic medication was not started or changed. Blood pressure fell in the next days, mainly on the second day after admission, to a plateau level reached on the fifth day. The pattern of the blood pressure course was comparable for patients with cerebral infarction and TIA; the level of blood pressure of the TIA patients however, was lower on all days after the event than that of the patients with cerebral infarction. Only 3 patients remained (slightly) hypertensive until discharge from the hospital. In 48 patients blood pressure values were available as measured two to six months after discharge, without having a change in antihypertensive or diuretic medication; in 14 of these patients hypertensive blood pressure figures were measured at that time. The conclusion of this study is that, after an early increase in blood pressure, on the first day after cerebral infarction or TIA, there is a spontaneous fall in the next days to normotensive levels in most patients. Treatment of hypertension in the acute phase of cerebral infarction or TIA is therefore in most cases not necessary and may even be dangerous. After discharge, blood pressure may increase again; it is therefore advisable to monitor the blood pressure a few months after the event. 
The cause of post-stroke hypertension is not clear. The stress of the event and neuronal (dys)regulation of blood pressure as a result of the brain damage have been suggested as possible explanations. In Chapter 8 a preliminary study on the course of both venous and urinary catecholamines and plasma renin activity (PRA) in relation to blood pressure measured the first 3 days after cerebral infarction is presented. The study comprises 10 patients. As expected, blood pressure fell on the second and the third day after the event. There was a significant fall in plasma epinephrine concentration on the third day. The plasma norepinephrine values remained constant on all three days. There was a marked and significant increase in PRA on the third day; the value was doubled as compared with the first day. No significant correlation was found between course of blood pressure and plasma catecholamines or PRA. When blood pressure was correlated with urinary catecholamines, however, a significant correlation was found for epinephrine and dopamine, but not for norepinephrine. It was concluded that the changes in blood pressure after cerebral infarction are mediated at least in part by changes in catecholamine production. 
In dit proefschrift beschrijven wij allereerst ons onderzoek met betrekking tot herseninfarcering als mogelijke bijwerking van medicamenteuze behandeling van hoge bloeddruk bij oudere patiënten. De laatste jaren zijn er in de literatuur steeds meer publicaties, die erop wijzen dat adequate behandeling van hoge bloeddruk ook bij oudere patiënten het ontstaan van hart- en vaatziekten, en ook het herseninfarct $k$ an voorkómen. Mede door de vergrijzing van de bevolking, is het derhalve te verwachten dat steeds meer ouderen met antihypertensieve geneesmiddelen zullen worden behandeld.

Bij oudere patiënten bestaan vaak een aantal ziekten naast elkaar, waardoor het noodzakelijk is dat zij met verschillende medicamenten behandeld worden. Juist door het gelijktijdig gebruik van geneesmiddelen, die elkaars werking kunnen beïnvloeden, en ook tenqevolge van de veranderde verwerking van het medicament in het lichaam (zoals veranderde uitscheiding) en de vaak veranderde reactie op een geneesmiddel (zoals grotere of kleinere gevoeligheid), komen bij oudere patiënten tweemaal zoveel bijwerkingen voor als bij jongere. Daarom is kennis van de mogelijke interacties van geneesmiddelen en van de wijziging van de werking van geneesmiddelen met het stijgen van de leeftijd, van groot belang om ongewenste werkingen van medicijnen te voorkomen.

Elk geneesmiddel veroorzaakt bijwerkingen. Herkenning van een ziekteverschijnsel als bijwerking is soms gemakkelijk, maar meestal is het moeilijk om een aandoening als ongewenste werking van een medicament te onderkennen. Nog moeilijker wordt het, als een geneesmiddel, dat voorgeschreven is om een bepaalde ziekte te voorkomen, juist deze ziekte als bijwerking heeft. Meestal zal in een dergelijk geval de ziekte niet als bijwerking van het preventief gegeven medicament worden aangemerkt, maar eerder als een falen van de preventie. Wij bestudeerden de mogelijkheid van een herseninfarct als bijwerking van geneesmiddelen voorgeschreven voor hypertensie. De reden om deze 
mogelijke bijwerking te gaan bestuderen, wordt in Hoofdstuk 1 beschreven. Het doel van de studie was, de vraag te beantwoorden of genoemde bijwerking voorkomt, en zo ja, of deze vooral door bepaalde geneesmiddelen optreedt, in hoeverre de ouderen een risicogroep vormen de bijwerking te krijgen en in welke frequentie de bijwerking optreedt.

Wanneer men van een ziekteverschijnsel vermoedt, dat het door een medicament veroorzaakt wordt, dan dient het ziekteverschijnsel op zijn oorzakelijk verband met het geven van het geneesmiddel, de toeschrijfbaarheid, beoordeeld te worden, om het te kunnen classificeren als "onwaarschijnlijk, mogelijk, waarschijnlijk of zeker". Er zijn verscheidene methoden gepubliceerd on deze oorzakelijkheid te bepalen. Wanneer deze methoden echter op hetzelfde geval worden toegepast, dan wordt de relatie tussen geneesmiddel en vermoede bijwer$k$ ing vaak verschillend beoordeeld. Ook wanneer één methode op een bepaald geval werd toegepast door verschillende onderzoekers werden verschillende uitkomsten verkregen. Het vaststellen van een ziekteverschijnsel als geneesmiddelenbijwerking is derhalve niet eenvoudiq. In Hoofdstuk 2 worden twee belangrijke methoden ter beoordeling van bijwerkingen beproefd bij pogingen vast te stellen in hoeverre het herseninfarct $k$ an optreden als bijwerking van het diureticum furosemide, qegeven ter behandeling $v a n$ hoge bloeddruk, bij de door ons opgespoorde en verdachte gevallen. Enkel ondat er sprake was van een aanvaardbare tijdsrelatie tussen het geven van de furosemide en het optreden van het herseninfarct, werd de vermoede bijwerking als "mogelijk" beoordeeld. Belangrijke onderdelen van de beoordelingsmethoden, zoals verdwijnen van de ziekteverschijnselen na staken van het medicament, en hernieuwd optreden van de ziekteverschijnselen, nadat het medicament opnieuw gegeven werd, konden echter niet benut worden, aangezien het herseninfarct vaak blijvende ziekteverschijnselen teweegbrengt. Omdat hypertensie juist de belangrijkste risicofactor vormt voor het krijgen van een herseninfarct, werd dit als goede alternatieve verklaring aangemerkt. De patiënten, van wie wij vermoedden dat $z i j$ een herseninfarct als gevolg van hun antihypertensieve therapie gekregen hadden, hadden allen evenwel een opmerkelijke en 
niet verwachte daling van de bloeddruk, gemeten kort na het infarct en zij vertoonden allen een verhoogde hematocriet. Deze ons inziens belangrijke factoren, konden niet in de methoden verwerkt worden. Derhalve werd geconcludeerd dat de meest gebruikte methoden, ter beoordeling van een geneesmiddelenbijwerking, niet geschikt zijn om te bepalen of en in hoeverre het herseninfarct $k$ an optreden als bijwerking van (onjuiste) hypertensiebehandeling.

In Hoofdstuk 3 wordt een overzicht gegeven van de in de literatuur beschreven gevallen van hersenischemie ontstaan door geneesmiddelen. Wij verzamelden 44 van dergelijke gevallen. De hersenischemie werd veroorzaakt door allerhande bloeddrukverlagende middelen zoals diazoxide, nitroprusside, lisdiuretica, methyldopa, vaatverwijders, betablokkers en angiotensine-converting-enzym remmers. Wanneer de daling van de gemiddelde arteriële bloeddruk (MAP), welke door de medicamenten teweeg was gebracht, gerelateerd werd aan de leeftijd van de patiënten, werd geconstateerd dat bij jongere patiënten steeds een aanzienlijke daling van de MAP was opgetreden, terwijl bij de oudere een veel geringere daling van de MAP tot hersenischemie aanleiding had gegeven. Geconcludeerd werd dat speciaal oudere patiënten risico lopen hersenischemie als bijwerking van hypertensiebehandeling te krijgen. Ter verklaring is te denken aan een verminderde gevoeligheid van de baroreceptorreflex op oudere leeftijd, een mogelijk falen van de autoregulatie van de hersenen, waardoor de hersendoorbloeding direct afhankelijk is van de bloeddruk, en een daling van de hersendoorbloeding met het stijgen van de leeftijd.

Hoofdstuk 4 beschrijft het vooórkomen van qenoemde bijwerking onder verpleeghuispatiënten. Daartoe werd een vragenlijst verstuurd naar de medisch directeuren van de 322 Nederlandse verpleeqhuizen, ondat verondersteld werd dat patiënten met een herseninfarct, ontstaan tengevolge van hypertensiebehandeling, aldaar qevonden zouden kunnen worden. De respons op de enquête bedroeg 55\%. Er werden 30 gevallen gemeld door 25 verpleeghuisartsen. Allerlei bloeddrukverlagende middelen werden gerapporteerd, maar vooral furosemide en methyldopa. Van de 30 gevallen waren er 9 goed gedocumenteerd met volledige opgaaf van bloeddrukken, zoals gemeten voor instelling van de 
behandeling en direct na het ontstaan van de verschijnselen van hersenischemie. Bij alle negen (oudere) patiënten was er sprake van een aanzienlijke bloeddrukdaling. Uit deze studie werd geconcludeerd dat behandeling van hypertensie bij oudere oatiënten voorzichtig en met de juiste middelen dient te geschieden, waarbij een geleidelijke daling van de bloeddruk moet worden naqestreefd, ten pinde hersenletsel te voorkomen.

In Hoofdstuk 5 wordt een studie beschreven, verricht onder 178 patiënten, die in een algemeen ziekenhuis werden opgenomen wegens een herseninfarct of een zogenaande transient ischaemic attack (TIA). Bij 100 van deze patiënten waren bloeddrukgegevens beschikbaar, verkregen via de huisarts en gemeten enkele dagen tot maximaal 1 jaar voor het ontstaan van de hersenischemie. Alleen deze 100 patiënten werden in de studie betrokken. Bij zeven van hen was in de 3 weken voorafgaande aan de hersenschade, antihypertensieve dan wel diuretische medicatie gestart of de dosis ervan verhoogd. Zij werden alle zeven getroffen door een herseninfarct. Bij drie van hen was furosemide gestart wegens hypertensie, bij twee wegens decompensatie van het hart. Bij één patiënt was de furosemidedosis verhoogd wegens oedeem van de enkel en bij één was de dosis van het combinatiepreparaat AdelphanEsidrex $R$ verhoogd wegens persisteren van de hoge bloeddruk. De bloeddruk van de 100 patiënten, zoals gemeten kort na opname, werd vergeleken met de waarde ongegeven door de huisarts. Bij 71 patiënten werd een stijging van de bloeddruk geconstateerd en bij 29 een daling na het hersenletsel. De 3 patiënten, aan wie furosemide qeqeven was wegens hypertensie, vertoonden de grootste daling van de bloeddruk van alle patiënten (een daling van de MAP van respectievelijk 18, 19 en $22 \%)$. De patiënt bij wie de dosis van Aldephan-EsidrexR was verhoogd, had een daling van de MAP van $12 \%$. Bij deze vier patiënten waren er ook tekenen van bloedindikking (hoge hematocrietwaarde). Naar onze mening heeft bij deze 4 oudere patiënten de start (of verandering) van de medicatie een belangrijke bijdrage geleverd in het ontstaan van het herseninfarct. Bij de andere 3 patiënten was er een gerinqere daling (10\%) of zelfs een toename ( 5 en 15\%) van de MAP, en er waren geen tekenen van bloedindikking. Omdat bij hen ook 
andere risicofactoren voor het ontstaan van een herseninfarct aanwezig waren (boezemfibrilleren met een snelle kamerfrequentie en staken van acenocoumarol 1 week voor het ontstaan van het infarct) werd de relatie met de medicatiewijziging als minder warschijnlijk beoordeeld. Uit deze studie werd geconcludeerd dat vooral de sterk werkende lisdiuretica, zoals furosemide, een zodanige bloeddrukdaling teweeg kunnen brengen, dat er daardoor hersenischemie kan ontstaan. Omdat er vele betere en veiligere antihypertensieve middelen bestaan, dienen de lisdiuretica dan ook niet ter behandeling van hoge bloeddruk te worden voorgeschreven.

Hoofdstuk 6 is de Engelse vertaling van het Nederlandse artikel, aangeboden aan het Nederlands Tijdschrift voor Geneeskunde. Het doel van dit te publiceren artikel is, om genoemde bijwerking onder de aandacht van alle Nederlandse artsen te brengen. Er werd een selectie gemaakt uit de 100 patiënten, zoals beschreven in Hoofdstuk 5, waarbij alleen de 54 patiënten met een herseninfarct, die antihypertensieve dan wel diuretische medicatie gebruikten, werden bestudeerd. In deze studie worden de ziektegeschiedenissen van de 3 patiënten, die met furosemide waren gestart wegens hypertensie, gepresenteerd. Uit deze studie $k$ an worden opqemakt, dat bij circa $6 \%$ van de patiënten die met een herseninfarct in een ziekenhuis werden opgenomen, en antihypertensieve medicatie gebruikten, deze medicatie heeft bijgedragen tot het ontstaan van de hersenischemie.

Het is bekend dat na een herseninfarct de bloeddruk meestal is verhoogd. Of deze "post-stroke" hypertensie behandeld moet worden, staat nog steeds ter discussie. Er zijn meldingen in de literatuur, dat het verlagen van de bloeddruk na een herseninfarct gevaarlijk kan zijn, in de $z$ in dat daardoor de hersenischemie toeneemt en het qeĩnfarceerde gebied vergroot wordt. Wij bestudeerden het spontane bloeddrukbeloop bij patiënten, die opgenomen waren wegens een herseninfarct of TIA. Deze studie is beschreven in Hoofdstuk 7. Tijdens de studieperiode werd antihypertensieve of diuretische medicatie niet qestart of gewijzigd. Er werden 63 patiënten bestudeerd. Bij 42 patiënten (67\%) werd een verhoogde bloeddruk gevonden op de eerste dag van opname. In de volgende dagen trad er een daling van de bloeddruk op, welke op de 
$2 e$ dag na opname het grootst was. Het bloeddrukniveau stabiliseerde zich op de 5e dag. Het patroon van het bloeddrukbeloop van patiënten met een herseninfarct en TIA was identiek, waarbij het bloeddrukniveau bij de patiënten met een TIA op alle 5 dagen na opname lager lag dan dat van de patiënten met een herseninfarct. Vlak voor ontslag uit het ziekenhuis werd bij nog slechts 3 patiënten (5\%) een ( 1 icht) verhoogde bloeddruk gemeten. Van 48 patiënten waren bloeddrukgegevens beschikbaar, gemeten twee tot zes maanden na ontslag uit het ziekenhuis. Nu werd bij 14 patiënten (29\%) een hypertensie vastgesteld. Uit deze studie wordt geconcludeerd, dat na een aanvankelijke bloeddrukstijging op de eerste dag na ontstaan van hersenletsel, de bloeddruk in de volgende dagen, en met name op de $2 e$ dag na opname, snontaan daalt tot normale waarden bij de meeste patiënten. Rehandeling van hoge bloeddruk in de acute fase van een herseninfarct of TIA is derhalve in de meeste gevallen onnodig en kan zelfs gevaarlijk zijn. Na ontslag uit het ziekenhuis blijft controle van de bloeddruk noodzakelijk, daar deze bij een aantal patiënten weer stijgt.

De oorzaak van "post-stroke" hypertensie is niet duidelijk. Een mogelijke verklaring wordt gevonden in de stress, die het gebeuren met zich meebrengt, maar ook ontregeling van de bloeddruk te wijten aan de hersenschade of juist een regeling van de bloeddruk door de hersenen, als reactie op de hersenschade, is gesuggereerd.

In Hoofdstuk 8 wordt het beloop van de catecholamineconcentraties in bloed en urine en van plasma-renine-activiteit (PRA) in relatie tot de bloeddruk beschreven en wel in de eerste 3 dagen na een herseninfarct. Er konden 10 patiënten worden bestudeerd. Zoals verwacht, daalde de bloeddruk op de $2 e$ en $3 e$ dag ten opzichte van de le dag na opname. Er was een statistisch significante daling van de olasma adrenaline concentratie op de $3 e$ dag. De plasma noradrenaline concentraties bleven gedurende de 3 dagen op een constant niveau. Fr was een aanzienlijke en significante stijging van de PRA op de $3 \mathrm{e}$ dag; de concentratie verdubbelde ten opzichte van die van de le dag. Er werd geen significante correlatie gevonden tussen het bloeddrukbeloop en de plasma catecholamine concentraties of PRA. Wel bestond er een significante correlatie tussen de catecholamine concentraties van adre- 
naline en dopamine in de urine, maar niet van noradrenaline. De conclusie is, dat de bloeddrukverandering na een herseninfarct minstens ten dele wordt bewerkstelligd door of via verandering in catecholamineproduktie. 
Allen die aan de totstandkoming van dit proefschrift hebben bijqedragen, wil ik danken. Allereerst de patiënten voor hun onmisbare medewerking aan het onderzoek. De vele huisartsen en verpleeghuisartsen wil ik danken voor hun bereidwilligheid mij de nodige informatie te verschaffen.

R. Meyboom, hoofd van het Bureau Bijwerkingen Geneesmiddelen (Rijswijk) dank ik voor zijn enthousiaste medewerking.

E. Poels, neuroloog in het Canisius-Wilhelmina Ziekenhuis, werkte, zeer bereidwillig, aan een groot deel van het onderzoek mee, en ik dank hem voor zijn steun, adviezen en de gastvrijheid zijn afdeling voor het onderzoek open te stellen, dit met instemming van zijn collega's Dr. C. Frenken en Dr. M. Prick. Voorts kan ik terugzien op een zeer prettige samenwerking met en enorme hulp van de veroleging van afdeling 19 (hoofd Mw. W. van Sambeek) van het Canisius-Wilhelmina Ziekenhuis.

Wim Goossens, keuzevakstudent, dank ik voor zijn medewerking.

De laboratoriumbepalingen werden met grote nauwkeurigheid en enthousiasme verricht door J. Willemsen en Mw. A. Thissen-Jansen op het laboratorium voor experimentele en chemische endocrinologie (hoofd Prof. Dr. Th. Benraad) en door Mw. M. Jansen op het neurologisch laboratorium (hoofd destijds J. Kok). Ook ben ik dank verschuldigd aan $K$. Lamers, klinisch chemicus, voor zijn medewerking.

De tekeningen werden vervaardiad door J. Konings en C. Nicolasen van de afdeling Medische Illustratie, en vervolgens werden fotografische afdrukken gemaakt on de afdeling Medische Fotografie.

Het verzamelen van literatuur was mogelijk door medewerking van het personeel van de Medische Bibliotheek (hoofd Mw. S. Bakker) en van Mw. D. Graven van de bibliotheek Inwendige Geneeskunde.

De correctie van de engelse taal werd, immer vlot, verricht door de heer Th. van Winsen.

Gemma Wessel-Hooqstraaten ben ik veel dank verschuldigd voor de enorme inzet en zorgvuldigheid, waarmee zij de manuscripten op de 
tekstverwerker heeft gezet en met veel geduld steeds heeft bijgewerkt. Anky Verweyen en Ans Ruesen-Maandag waren bereid in te springen wanneer het nodig was.

Tot slot wil ik Marjan bedanken voor haar secretariële werk in de weekeinden en haar onmisbare steun. 
De schrijuer van dit proefschrift werd op 23 maart 1953 geboren te Haarlem. In 1972 behaalde hij aan het Canisius College te Nijmegen het einddiploma Gymnasium $\beta$.

Na het eerste jaar uitgeloot te zijn, studeerde hij vanaf 1973 Geneeskunde aan de Katholieke Universiteit te Nijmegen.

In 1978 behaalde hij het doctoraalexamen en in 1980 het artsexamen. In oktober 1980 begon hij zijn opleiding tot internist in de universiteitskliniek voor Inwendige Geneeskunde te Nijmegen (hoofd Prof.Dr. A. van 't Laar).

Van mei 1983 tot december 1985 was hij gedeeltelijk werkzaam binnen de werkgroep Klinische Farmacologie en Farmacokinetiek (leider Prof.Dr. F.W.J. Gribnau) van het laboratorium Farmacologie (hoofd Prof.Dr. C.A.M. van Ginneken) in welke periode het onderzoek verricht werd, waarvan dit proefschrift een verslag is.

Op 1 oktober 1985 voltooide hij zijn opleiding tot internist; vanaf 1 januari 1986 volgt hij de opleiding tot klinisch geriater in het Christelijk Psychiatrisch Centrum Bloemendaal te 's fravenhage (opleider J. van Nieuwkerk).

Hij is getrouwd met Marjan Wessels. 

Weqens zijn krachtige diuretische werking, met kans op ontstaan van hypovolemie en hersenischemie is furosemide, in "gewone" doseervorm $v$ an snel qeresorbeerd tablet, niet geschikt als anti-hypertensief middel.

(dit proefschrift)

Bij bejaarde patiënten $k$ an reeds door een relatief qeringe bloeddrukverlaqing hersenischemie ontstaan.

(dit proefschrift)

I I I

Tenzij er tekenen zijn van hypertensieve encephalopathie dient "post-stroke" hypertensie niet met antihypertensieve middelen behandeld te worden.

(dit proefschrift)

Bij naqenoeg alle patiënten met een herseninfarct daalt de qestegen bloeddruk spontaan binnen vijf daqen na het accident tot normale waarden.

(ait proefschrift)

De bloeddrukveranderingen, die kort na een herseninfarct optreden, zi.jn, minstens ten dele, toe te schrijven an verhoogde produktie $v a n$ catechol aminen.

(dit proefschrift) 
De huidiqe methoden ter bepaling van de toeschrijfhaarheid van bijwerkingen van geneesmiddelen zijn onvoldoende bruikbaar, aangezien zij niet toegespitst zijn op één bepaald orgaan.

VII

In qeval van een qeneesmiddelexantheem tijdens therapie voor exacerbatie van CARA, waarbij vaak zowel antibiotica als aninophylline worden qegeven, dient als de veroorzaker $v a n$ de allerqie naast aan het antibioticum, aan ethyleendianine gedacht te worden.

(Berg v.d. W en Ketel v.d. W, Ned T Geneesk 1983; 127: 1801-2)

(eigen waarneming)

VI I I

Diqitalisatie volgens de vuistregel van Birkenhäqer, thans niet meer door hemzelf, maar wel door anderen gehanteerd, zal bij de meeste patiënten ouder dan 70 jaar tot onderdosering leiden. (Birkenhäger $W$, Ned $T$ Geneesk 1982; 126: 394-5)

IX

Bi,j de behandeling $v a n$ decompensatio cordis is digoxine niet het qeneesmiddel van de eerste keuze, wanneer er een sinusritme bestaat. (Lipkin en Poole-Wilson P, Br Med J 1985; 291: 993-6)

Aangezien de farmacokinetiek van geneesmiddelen bij beiaarden aewi ziad kan zijn ten opzichte van die van jongeren, dient onderzoek van elk geneesmiddel naar dit aspect te qeschieden. 
De gewijzigde kinetiek van naproxen op oudere leefti,jd is voornamelijk toe te schrijven aan veranderde binding van dit qeneesmiddel aan serumeiwitten.

(Upton RA e.a., Br J Clin Pharmacol 1984; 18: 207-11)

XII

Het bestaansrecht $v$ an het specialisme $k l$ inische qeriatrie wordt in hoqe mate geschraagd door de constatering dat hoogbejaarde patiënten veelal $n$ iet adequat medisch behandeld worden.

\section{XIII}

Het medisch adaqium "qui bene purgat, bene curat" is in de hooqste mate geldig in de geriatrische praktijk.

\section{XIV}

Mits met de juiste kennis en toewijding verzorgd, is de roodwangmoerasschildpad in qevangenschap een lana leven beschoren.

P.A.F. Jansen

$\mathrm{Ni}$ jmeqen, 28 november 1986 


